\title{
The Energy Efficiency Post-COVID-19 in China's Office Buildings
}

\author{
Carlos C. Duarte *(i) and Nuno D. Cortiços (i)
}

check for updates

Citation: Duarte, C.C.; Cortiços, N.D. The Energy Efficiency

Post-COVID-19 in China's Office

Buildings. Clean Technol. 2022, 4,

174-233. https://doi.org/10.3390/

cleantechnol4010012

Academic Editors: Marjan Goodarzi and Reza Maihami

Received: 3 January 2022

Accepted: 25 February 2022

Published: 2 March 2022

Publisher's Note: MDPI stays neutral with regard to jurisdictional claims in published maps and institutional affiliations.

Copyright: (C) 2022 by the authors. Licensee MDPI, Basel, Switzerland. This article is an open access article distributed under the terms and conditions of the Creative Commons Attribution (CC BY) license (https:// creativecommons.org/licenses/by/ $4.0 /)$.

\author{
Building Science, Technology and Sustainability Lab, CIAUD—Research Centre for Architecture, \\ Urbanism and Design, Lisbon School of Architecture, University of Lisbon, Sá Nogueira Street, \\ University Campus, Alto da Ajuda, 1349-063 Lisbon, Portugal; ncorticos@campus.ul.pt \\ * Correspondence: carlosfcduarte@campus.ul.pt
}

\begin{abstract}
China promptly took the leading step to mitigate the spread of COVID-19, producing the first scientific guidelines assuming health above energy consumption and significantly changing HVAC/AHU operation. The research intended to fulfill the gap by measuring the impact of the guidelines on energy use intensity, $\mathrm{CO}_{2}$ emissions, and energy operation costs related to workplaces. The guidelines are long-term sector and industry trends following occupants' health and safety concerns, and today they are applied to nursing homes. The research extended the study to postCOVID-19 scenarios by crossing those settings with published reports on telework predictions. The methodology resorts to Building Energy Simulation software to assess the Chinese standard large office building on 8 climate zones and 17 subzones between pre- and post-COVID-19 scenarios under those guidelines. The outcomes suggest an upward trend in energy use intensity $(11.70-12.46 \%)$, $\mathrm{CO}_{2}$ emissions (11.13-11.76\%), and costs (9.37-9.89\%) for buildings located in "warm/mixed" to "subarctic" climates, especially in colder regions with high heating demands. On the other hand, the figures for "very hot" to "hot/warm" climates lower the energy use intensity (14.76-15.47\%), $\mathrm{CO}_{2}$ emissions (9\%), and costs (9.64-9.77\%).
\end{abstract}

Keywords: COVID-19; guidelines; China; office buildings; energy consumption; $\mathrm{CO}_{2}$ emissions

\section{Introduction}

The first cases of SARS-CoV-2/COVID-19 (severe acute respiratory syndrome coronavirus 2/coronavirus disease 2019) were diagnosed in Wuhan, China, at the Huanan Seafood Wholesale Market on 10 December 2019, which resulted in 41 hospitalized city residents sharing the same symptoms. However, earlier studies mention its simultaneous presence in Spain and Italy [1]. On 11 February 2020, the WHO named the disease COVID-19 and a month later, on 11 March, declared a global pandemic [2].

The social disruption occurred immediately, and the 11 million Wuhan residents were the first to experience the economic and social consequences due to COVID-19, leading to a lockdown that affected 48 cities and 4 provinces in China. The initial actions affected half a billion Chinese inhabitants to halt the spreading virus, as supplementary measures constrained the population's mobility [3]. On 1 May 2020, China celebrated the Lunar New Year by reopening its economy; people slowly started returning to the workplace [4] with imposed new rules to mitigate SARS-CoV-2 spreading indoors.

The initial pandemic development set in motion the production of guidelines to tackle the SARS-CoV-2 transmissibility risk [5], paving the road to ensure a safe return to the workplace. The reopening raised doubts about the best practices and procedures to apply on air-related systems as the virus spread via airborne microdroplets or aerosols suspended in airflows channeled by HVAC systems, with harmful effects in indoor spaces such as office buildings [6,7]. This situation forced the World Health Organization (WHO) and other worldwide institutions to promptly react, launching a set of measures (guidelines), from HVAC/AHU to social restrictions, to mitigate the virus spread in buildings, which empowered telework figures across the knowledge-based economies [7]. 
Therefore, the researchers analyzed the main COVID-19 guidelines published by the WHO as well as Chinese and US institutions (see Table 1 below). The WHO published a set of guidelines to prepare the new everyday life, aside from supplementary measures, consisting of non-travel/commuting orders, limited public meetings, and the promotion of telework policy. In China, the end of the Spring Festival set a date for the economy to reopen, therefore enforcing the new guidelines on HVAC/AHU systems, especially concerning safety in the ventilation of office buildings. These guidelines were based on the knowledge of the 2003 SARS-CoV-1 epidemic's Sick Building Syndrome (SBS) awareness and nursing home settings. In February 2020, the Chinese Association of Refrigeration (CAR) assembled an "Expert Group on Air Conditioning (Heating) System Fight against COVID-19" (translated by the authors from Chinese using Google Translator; more information at http:/ / www.car.org.cn/index.php?s=/articles_1348.html, accessed on 25 March 2021) with the role of drawing a document targeting building managers and occupants on how to correctly use the HVAC system to prevent virus dissemination, reduce the risk of cross-infection, and promote health and safety at work and in life in general [8]. The Architectural Society of China (ASC) and the People's Medical Publishing House $(\mathrm{PMPH})$ published their guidelines a few weeks later. Five months later, the Chinese Center for Disease Control and Prevention (CDCP) published a document focused on operating HVAC systems in buildings.

Table 1. Summary of the published COVID-19 guidelines issued by WHO, China, and the USA.

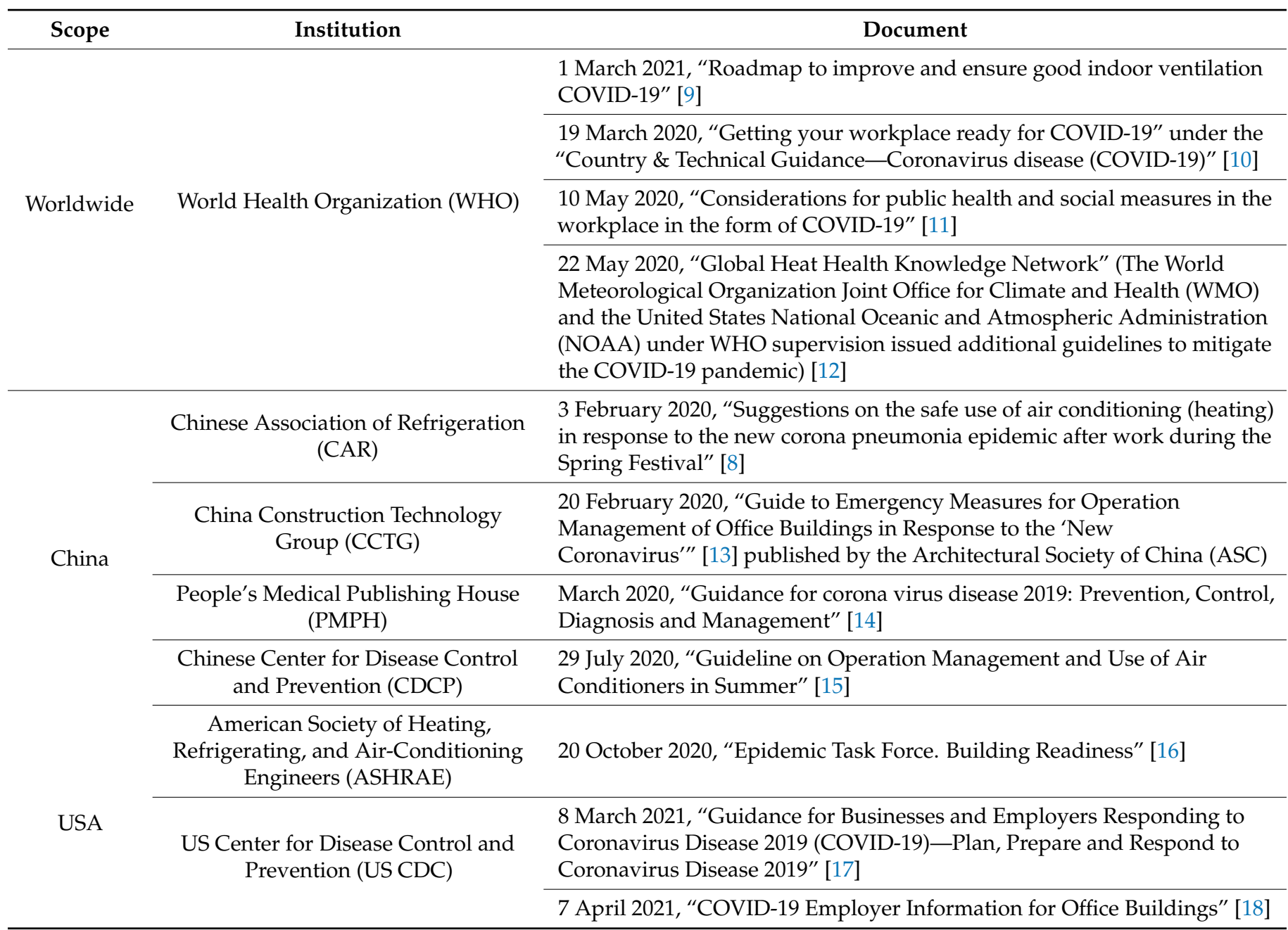

Several US institutions (e.g., United States Environmental Protection Agency (US EPA), National Institute for Occupational Safety and Health (NIOSH), American Industrial 
Hygiene Association (AIHA), Occupational Safety and Health Administration (OSHA)) followed the SARS-CoV-2 mitigation developing guidelines that became prominent in the pandemic fight, such as those from the Center for Disease Control and Prevention (US CDC) and the American Society of Heating, Refrigerating, and Air-Conditioning Engineers (ASHRAE). The first addresses employers, owners, managers, and operation specialists, guiding the daily activities in a working environment. The second presents a set of informative and systematically updated guidelines oriented toward building control and HVAC systems to regulate ventilation rates, temperature sets, and indoor air quality.

The Table 1 institutions recommend consistent and identical office building HVAC systems measures despite the country, location, or energy patterns. However, they diverge on details, reflecting the unknown aspects of virus transmission and building features [5]. Narrowing our focus to Chinese guidelines, CAR specifications align with prior studies targeting SBS and measures in place in nursing homes. Table 2 compares the CAR figures on AHU units applied in commercial buildings, before and after COVID-19 "Operations Guidelines". Slight adjustments were made toward air quality and high ventilation rate as follows: the outside air from $>60$ to $>70 \%$, re-entrainment from $<40$ to $<30 \%$, and exhaust air transfer rate to $0 \%$. The outdoor air rate per person rises from 7 to $10 \mathrm{~L} / \mathrm{s}$; on the contrary, the outdoor air per area did not change. On "air distribution", CAR requests avoiding unidirectional distribution across rooms and favoring single air use, policies of natural ventilation on open windows under climate assessment, and increased in-duct filters from G4 to F7 (ISO ePM1 70-80\%). However, free-standing high-efficiency particulate air filters (HEPAs) and ultraviolet germicidal irradiation (UVGI) were not mandatory. Indoor sets became simplified according to China's different climate zones $(\mathrm{CZ})$ and just requested operation above 16 to $18{ }^{\circ} \mathrm{C}$, over $40 \%$ of relative humidity.

Table 2. CAR guidelines comparison before and during COVID-19 [8,19].

\begin{tabular}{|c|c|c|c|c|}
\hline Operation Guidelines & & Before COVID-19 & During COVID-19 & $\neq$ \\
\hline \multirow{5}{*}{ Ventilation } & Outside air (OA) & $>60 \%$ & $>70 \%$ & $10 \%$ \\
\hline & Re-entrainment & $<40 \%$ & $<30 \%$ & - \\
\hline & $\begin{array}{c}\text { ERV/exhaust air Transfer rate } \\
\text { (EATR) }\end{array}$ & $6 \%$ & $0 \%$ & - \\
\hline & Outdoor air rate per person & $7 \mathrm{~L} / \mathrm{s}$ & $10 \mathrm{~L} / \mathrm{s}$ & $3 \mathrm{~L} / \mathrm{s}$ \\
\hline & Outdoor air rate per area & $0.4 \mathrm{~L} / \mathrm{s}$ & - & - \\
\hline \multirow{2}{*}{ Air distribution } & Mechanical & $\begin{array}{l}\text { Unidirectional across } \\
\text { rooms }\end{array}$ & $\begin{array}{l}\text { Avoid room } \\
\text { interchange }\end{array}$ & - \\
\hline & Mechanical + natural & Yes & $\begin{array}{l}\text { Under climate } \\
\text { assessment }\end{array}$ & - \\
\hline \multirow{3}{*}{ Filtration and disinfection } & MERV filter & G4 (MERV 6-8) & $\begin{array}{l}\text { F7 (MERV } 13 \\
\text { equivalent) }\end{array}$ & - \\
\hline & HEPA filter & No & No & - \\
\hline & UVGI & No & No & - \\
\hline \multirow{2}{*}{ Indoor setpoints } & Ambient temperature & $\begin{array}{c}\text { Winter }>18^{\circ} \mathrm{C} \\
\text { Summer } 24-26^{\circ} \mathrm{C}\end{array}$ & $\begin{array}{l}>16^{\circ} \mathrm{C} \text { to } 18^{\circ} \mathrm{C} \\
\text { no maximum }\end{array}$ & - \\
\hline & Relative humidity & $\begin{array}{c}\text { Winter }>40 \%<50 \% \\
\text { Summer }>50 \%<60 \%\end{array}$ & $>40 \%$ & - \\
\hline
\end{tabular}

Overall, the guidelines focus on the "ventilation" field promoted by "open-window" policies, raised outdoor airflow rates, and air-flush of one to two hours pre- and postoccupancy at maximum airflow rate. In addition, cleaning and filtration upgrades to HVAC systems are also suggested by installing HEPA filters and UVGI devices [5]. Nevertheless, settings show discrepancies in indoor ambient temperature (AT) and relative humidity (HR) 
setpoints or when rotary heat recovery devices are in use $[5,20]$. Therefore, it is expected that the guidelines' recommendations should increase the annual energy consumption related to office buildings mainly upon higher airflow rates and filtration device upgrades [16,21-24].

Regarding this matter, and even before the pandemic arose, Omar [25] ran a study on intelligent building (IB) design and its evaluation criteria to decrease energy consumption and costs, applying a multi-criteria methodology. The author concluded that the definition of an IB is complex and vast, including health, safety, and indoor comfort concerns while seeking to rationalize environmental and energy-related parameters. In addition, the study highlights that IB will become the "new" standard for the architecture and construction industry. During the pandemic, Cutler and Summers [23] ran a study on SARS-CoV-2 mitigation costs in the US and highlighted the rising importance of health and safety aligned with climate change or energy efficiency (EE), even limited to the cited territory; the same behavior also happened elsewhere. Awada et al. [26] studied the implications on occupant health in buildings following the COVID-19 pandemic from the perspective of building professionals, whose views demonstrate the significant effects on the future design, construction, and operation of buildings pushing for occupant health based on the pandemic experience. The outcomes address the current research, demonstrating the impact of those changes in workplace layout, occupancy rates, and HVAC settings. The previous three studies focus on enhanced and prioritized aspects by the COVID-19 guidelines, which are the importance of health, safety, and indoor air quality over energy consumption. A study by Zheng et al. [20] (p. 10) supports this claim by concluding that the concern of prioritizing health over comfort or efficiency leads to an energy consumption increase of $128 \%$ on a Chinese public building during the pandemic, as assessed and published by the Building Energy Research Centre of Tsinghua University (THUBERC) in 2020. In similar research on the Chinese building stock, Feng et al. [27] drew the energy consumption breakdown of some cities-limited to Beijing, Shanghai, and Guangzhou—and concluded that "cooling", "heating", and "fans" weighed together consist of, on average, 45.79\% of the total energy consumption breakdown. Both sets of data demonstrate the potential impact of COVID-19 guidelines, on one side for the overall building performance, and on the other side, some HVAC-related fields translating into energy overconsumption and $\mathrm{CO}_{2}$ emissions $\left(\mathrm{CO}_{2} \mathrm{e}\right)$ growth. Moreover, Ascione et al. [28] oversaw the design of COVID-19 guidelines to ensure safety and health in classrooms. They pointed to an impact on energy consumption due to maximized mechanical ventilation (fresh air and airflow rates) under HVAC systems operation, in addition to new features to help reduce air interchange and control airflow dispersion. Although the study only covers educational facilities, it is likely suitable for large office buildings. The prior study conclusion is not unique; other authors [16,21-24,29] reported the same prediction for future indoor layouts pushing energy consumption and $\mathrm{CO}_{2} \mathrm{e}$. The ASHRAE Handbook 2019 (Chapter 62 "Ultraviolet Air and Surface Treatment") states the following: "The major costs of owning and operating a UVC system include ( . . ) energy costs (direct cost of lamp operation plus impact on heating and cooling energy consumption)" and "Increased ventilation adds to heating-and-cooling coil loads and may also affect fan energy use" [30] (p. 62.9). Taylor Engineering published a COVID-19 white paper to discuss the guidelines and recommendations from organizations in the USA, including the ASHRAE, CDC, and WHO, where ventilation experts raised concerns about airflow rate growth and concluded that it has a " . . ) significant negative impact on both energy costs and thermal comfort." [21] (p. 23), in addition to the need to mount UV-C devices pressing even more on energy consumption (p. 33). Nadel [22], reacting to the prior study, wrote an article on reducing COVID-19 risks in commercial buildings without wasting energy to control overconsumption and higher $\mathrm{CO}_{2} \mathrm{e}$ with higher outdoor airflow rates. The author advises ventilation system adaptations and filtration device upgrades to balance the parameters of health, comfort, and energy use. Nevertheless, the study does not cover building a specific use and directly targets the USA context; the research team considers outcomes valid in Chinese territory due to the universality of HVAC systems' layout and operation in large office buildings. Si et al. [31] unveiled the 
effect of COVID-19 on energy exploitation and consumption in China, following the impact of major global events and underlining the disrupters, from social to industry patterns. The study findings demonstrate that the exploitation, followed by the power and gas sectors, were the most impacted by pandemics leading to negative supply over demand, which cut the oil, power, and gas sectors' capacity, pressing energy insecurity and poverty. The study underlines the importance of measuring the broader effect of guidelines, such as the impact on energy and $\mathrm{CO}_{2}$ emissions. Cortiços and Duarte [32] ran an analysis on US "high-rise" office buildings under COVID-19 guidelines and how they affect energy consumption, costs, and $\mathrm{CO}_{2} \mathrm{e}$ in nine US ASHRAE-IECC climate zones. The authors realized that energy demand does not show homogenous behavior when comparing preand post-COVID-19 scenarios. The outcomes show that for and above CZ 4 (mixed-humid), the relative usable energy rose, on average, by $21.72 \%$, while under that threshold, it decreased by $11.92 \%$. This study relates in similarity and scope with this research despite the geographic differences. Kang et al. [33] developed a study on "changes in energy consumption according to building use type during the COVID-19 pandemic in South Korea". They concluded that office building electricity rose from January to March 2020 with a $(+) 1.5 \%$ peak at the latter under social distancing measures (level 1$)$. Nonetheless, the year ended with an average of less, $(-) 1.36 \%$, due to lockdown enforcement (level 2) and savings from shutting down the electronic equipment. Natural gas faced even more significant cuts, achieving a yearly average of $(-) 7.31 \%$ to reduce heating and hot water consumption, which shows a contrasting tendency against the overconsumption claim. By the same token, Gui et al. [34], in a report about the impact of COVID-19 on higher education building energy use and implications for future energy studies, reported a consumption cut of $9646.933 \mathrm{kWh}$, or around $24.88 \mathrm{kWh} / \mathrm{m}^{2}$, of energy use intensity (EUI) during the academic year (17 February 2020 to 21 February 2021, and from 18 February 2019 to 16 February 2020) on HVAC management by overseeing a sample of 122 buildings across five campuses at Griffith University, located in Southeast Queensland, Australia. On a wider scale, Wang et al. [35], in their study on uncovering the impact of the COVID-19 pandemic on energy consumption between pandemic-free scenarios and actual electricity consumption in China, state that electricity has dropped by $(-) 29 \%$ due to the COVID-19 epidemic (January to August 2020) compared to the 2015 to 2019 period. After August 2020, the figure flopped from negative to positive as the Chinese economy recovered.

Regarding the operation of HVAC systems to mitigate SARS-CoV-2, some studies already point in some directions to decrease virus transmissibility and improve EE at the same time. Aviv et al. [36] ran a study on fresh air under COVID-19's indoor ventilation to estimate the global energy savings potential of coupling natural ventilation with novel radiant cooling strategies. Upon raising concerns about energy costs due to the amount of conditioned fresh air used, standard HVAC systems were developed to address COVID-19 concerns. They proposed a modified ASHRAE code/solution to decrease energy demand by $10-45 \%$ in 60 key international cities in all major CZ while increasing fresh air intake to mitigate COVID-19. The HVAC proposed solution pushes for natural ventilation within a radiant system to improve operations, cutting cooling needs by 100 days mid-season. The study aligns with our research hypothesis of energy consumption disruption under COVID-19 codes. Faulkner et al. [37] ran an investigation of HVAC operation strategies for medium office buildings during the COVID-19 pandemic and concluded-resorting to Denver, Colorado climate settings-that ASHRAE's recommended MERV 13 filters reduce the virus concentration, on average, by 10\% compared to MERV 10 filters; however, the use of these filters presses the energy consumption about 3\%. In addition, $100 \%$ outdoor air operation reduces the virus concentration by $11 \%$ compared to MERV 10 (and 1\% compared to MERV 13) but increases heating energy consumption by $54 \%$ during winter and slightly during summer. On the contrary, HEPA filters, due to their high air resistance, increase the indoor virus concentration and the energy consumption by $12 \%$ compared to MERV 10 filters. Mokhtari and Jahangir [38] studied the effect of occupant distribution on energy consumption and COVID-19 infection in a Tehran university building under the current 
air exchange rate, class duration, and working hours equilibrium to better serve the user's health while ensuring EE. The results showed that an optimal distribution reduces infection by $56 \%$ and energy consumption by $32 \%$. The studies fulfill our research hypothesis by proposing revisions of space layout and user distribution in future workplace layouts by focusing on safety and health while simultaneously reducing energy-related costs. Lastly, Schibuola and Tambani [39] pursued highly energy-efficient ventilation to limit COVID-19 contagion in school environments through simulations based on high mechanical ventilation and facemasks to build a safe environmental/indoor viral concentration and decrease the infection risk. They concluded that HEAHU operating on monitored $\mathrm{CO}_{2}$ triggers an efficient $\mathrm{ACH}$ to optimize indoor air concentrations. The proposed operating model could deliver high-EE by reducing consumption from $60 \%$ to $72 \%$ when installed in an existing naturally ventilated classroom. The presented working mechanism could, in the future, help to prevent buildings' overconsumption by offering an adaptive mode to users' presence readings, which can help to follow our research outcomes.

Another aspect that must be considered is the symbiotic relationship of architecture's passive components and active systems to target the optimal indoor environmental conditions. In this way, Lourenço et al. [40], in the near-zero Solar XXI building, located in Lisbon, Portugal, assessed with EnergyPlus software the integration of optimized passive architecture solutions (vents above the door frame, earth tubes, adjustable blinds, thermal mass construction) and active systems (south facade building integrated photovoltaic, lighting sensors), together with building control and monitoring technologies. The authors concluded that intelligent buildings with automated control systems display better performance dealing with indoor thermal comfort, air quality, and illumination.

The research team highlights the widely mentioned content of COVID-19 guidelines concerning "social distancing" recommendations and remote work policies, e.g., telework and hybrid work models [5]. This trend reduces the building occupancy and pushes for new layouts increasing the area/volume per user (worker or visitor), with disruptions on energy consumption, especially on "heating", "cooling", "lighting", and "ventilation" operations. On 23 November 2020, the McKinsey Global Institute published a report on the future of remote work worldwide, considering 2000 tasks and 800 jobs in nine countries using the MGI's workforce model based on the Occupational Information Network $\left(\mathrm{O}^{*} \mathrm{NET}\right)$. After the pandemic experience, the report forecasted the hybrid models affecting the highest educated and well-paid workforce. In China, the model points to an effective potential without productivity loss of $16 \%$. However, the theoretical maximum could reach the $22 \%$ mark [41] (Exhibit 3), which paves our research hypothesis on teleworking figures. He et al. [42] considered that China's job seekers were more likely to accept remote positions even at lower incomes. Both statements corroborate China's figures in telework during the pandemic, which reached $75 \%$ of the urban working population and triggered significant investments in communications networks [43].

The research focuses on China, as it is currently the world's second-largest economy (17.9\% of global GDP) [44], displaying an average GDP growth of $8.69 \%$ since 2000 [45]. The Chinese government intends to replace manufacturing for services [46] with an increase in financial and IT industries, which have traditionally occupied large office buildings with company headquarters employing millions of workers in major cities. In the postpandemic era, remote work policies have the potential to change the game, as telework figures in China reveal an upward tendency even before COVID-19: in 2005, there were 1.8 million registered remote workers, increasing to 3.6 million by 2014 and 4.9 million by 2018. These figures account for $8 \%$ of the construction industry, $9 \%$ of the service industry, and $24 \%$ of the IT industry [47]. Therefore, telework appears to be a practice to consider in the Chinese working environment as forecasted by McKinzie [41] (Exhibit 2-3) and NRI reports [43]. Besides this, China has a vast territory with a broad spectrum of climate zones (CZ) [48], each with different building envelope code standards that assess building energy performance under different locations and conditions. 
On the whole, the COVID-19 guidelines pressure work environments to adapt to a new paradigm, a "new normal", where health and safety become key standards in the postpandemic world following a previous social trend. However, it is plausible that this leads to energy overconsumption and rising $\mathrm{CO}_{2}$ emissions in buildings [16,21-24,29]. At the same time, it is still unclear if COVID-19 recommendations in working environments will persist after the pandemic ends; if not, their continuity will defy the international environmental agreements goals. Moreover, the transition from offices to residential buildings due to remote work policies, shifting energy consumption and $\mathrm{CO}_{2}$ e patterns, raises the question of whether these working models will compensate for energy and financial disruption from a local to a broader (national) scale. To address the unknown, the research intends to fill this gap by accounting for the impact of the COVID-19 guidelines on Feng et al.'s [49] standard office building archetype, covering Bai et al.'s [48] 8 climate zones and 17 subzones for China, under telework figures forecast by the McKinsey Global Institute [41]. The aim is to measure the variation in usable energy consumption (\% and $\left.\mathrm{kWh} / \mathrm{m}^{2} \mathrm{yr}\right), \mathrm{CO}_{2} \mathrm{e}(\%$ and tonne $/ \mathrm{CO}_{2} \mathrm{r}$ ), and annual operation costs (USD/kWh/yr) by showing the differences between a baseline pre-pandemic scenario (pre-C19) and two posterior ones (post-C19 $78 \%$ and $84 \%$ ). Furthermore, there is an expectation of identifying eventual energy-related variations, trends, and patterns in different $\mathrm{CZ}$.

To achieve this, the research team resorted to a Building Energy Simulation (BES) methodology that consists of five sequential steps (see Figure 1 below). The BES methodology allows assessing and predicting the thermal and energy performance by resorting to a whole-of-building energy simulation software. It can be used as a means of diagnosis or to evaluate the impact of proposed retrofit strategies (in our case, the impact of the COVID19 guideline recommendations) either in the buildings' constructive features or systems and schedules (e.g., HVAC, occupation, lighting, air rates, AT setpoints) [50,51]. Coakley, Raftery, and Keane [51] recommend BES tools to assess the performance of key quality features during the building lifecycle. Shin and Haberl [52] stepped forward by reviewing HVAC thermal behavior operation using energy simulation software and concluded that this method could assist designers in their system planning.

The research used the LEED-approved Cove.tool [53] as its energy simulation tool. Cove.tool is a web-based software with an intuitive interface to assist architects and engineers in simulating building efficient designs and retrofits. The scientific community also follows the reliability of available software to perform energy analysis. Garwood et al. [54] conducted a review on "energy simulation tools" and categorized Cove.tool under "simplified calculation methodology" upon degree-days, bin weather data, and resistance-capacitance assessment. Their simulation is applied to a Building Energy Model $\left(\mathrm{BEM}^{\prime}\right)$ passive and active systems under weather conditions, envelope specifications, and features relevant to the thermal building assessment. Forouzandeh et al. [55] also reviewed similar software and validated 25 , while categorizing 8 , including the Cove.tool software, under the statistical method with an empirical or pre-simulated dataset to estimate energy consumption. Officially known as the Normative Calculation Method, it follows the calculation standards developed by the European Committee for Standardization (CEN) and the ISO (International Organization for Standardization) (ISO/FDIS 13790:2006). The Cove.tool delivers a wide range of outcomes per carrier, such as primary energy consumption and $\mathrm{CO}_{2} \mathrm{e}$, following an hourly/monthly schedule. 


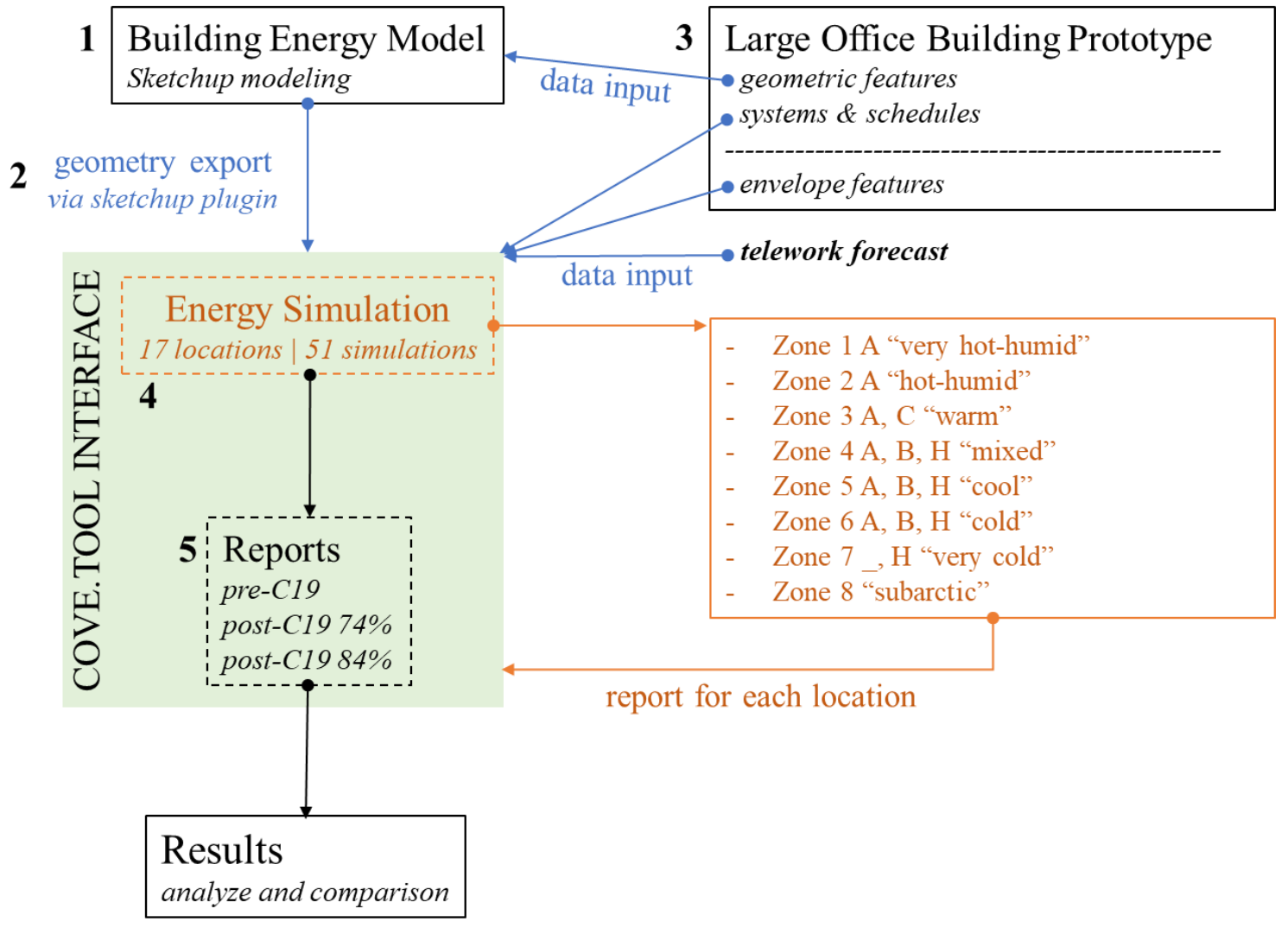

Figure 1. Diagram of the five-step methodology.

The study shows that the annual usable energy consumption, $\mathrm{CO}_{2} \mathrm{e}$, and energy costs rise, but only in office buildings located in regions with cold climates ("warm/mixed" to "subarctic") comparing the pre-C19 and post-C19 scenarios. In "very hot" to "hot/warm" climates, the tendency inverts pointing toward savings in all fields. These outcomes intend to pave the way for future adjustments in operation and construction guidelines: passive elements, active systems, operation schedules, IoT engagement, and self-learning technologies related to user comfort and energy efficiency.

From a broader perspective, the research's conceptual matrix can be extended to other regions and countries and other non-residential building archetypes using a similar methodology, creating the foundation to predict the impact of the guidelines in different contexts and pushing for further development adjustments and complementary measures.

The study targets the awareness of regulators, the related scientific community, the market players, and field professionals and associations.

\section{Materials and Methods}

The research resorted to the LEED-approved software Cove.tool [53] to run a total of 51 simulations on a Chinese office building prototype model in 17 locations (8 CZ and 17 subzones) under a BES methodology to assess its energy-related performance in three scenarios: prior (pre-C19) and posterior (post-C19 78\%, and post-C19 84\%) to the COVID-19 pandemic.

The research adopted a five-step BES methodology. The first step consists of 3D modeling of the office building standard prototype geometry features in Sketchup 2017 software (more information at https: / / www.sketchup.com/, accessed on 29 April 2021) to enable the creation of a BEM to be simulated. The BEM baseline follows Feng et al.'s [49] (pp. 4-123-4-125) and Feng and Levine's [56] (pp. 7,8) Chinese office building prototype model features and specifications (see Table 3 and Figure 2 below). The prototype is built 
over existing building surveys in China, Chinese building design institutes guidelines, and the PNNL-AHSRAE's [57] prototype building models [58].

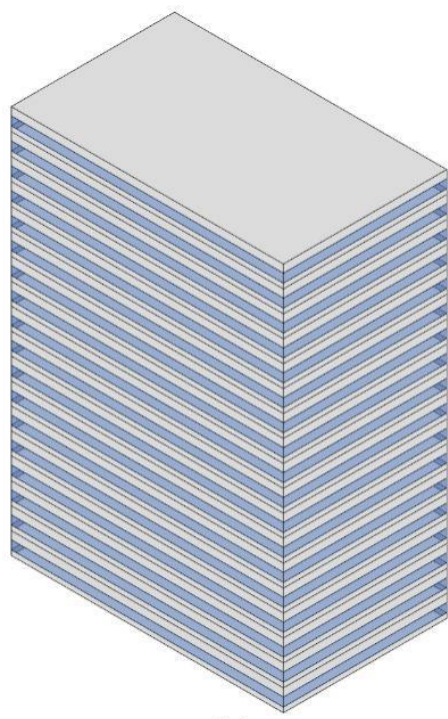

(a)

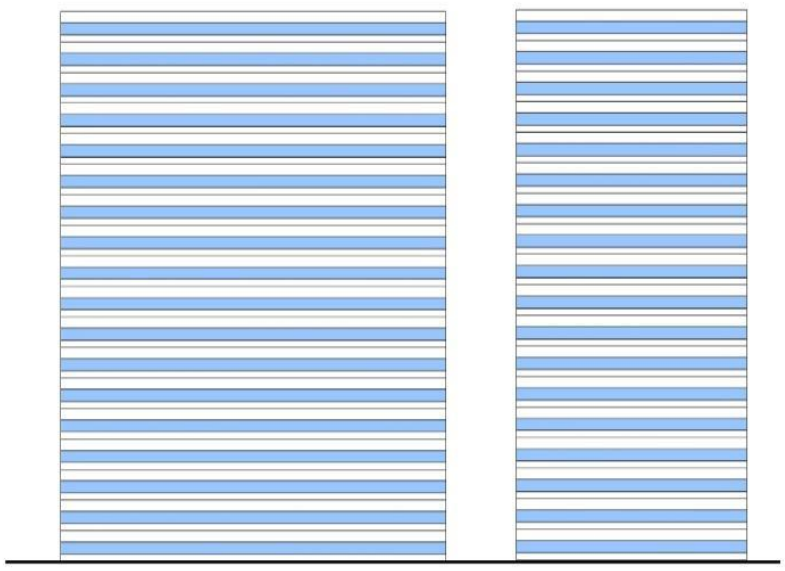

(b)

Figure 2. Standard Chinese office building model geometry: (a) isometric perspective; (b) west and south elevation. Modeled by the authors following Feng et al., description [49] (pp. 4-123-4-125).

Table 3. Summary of the adopted standard Chinese office building prototype features $[49,56]$.

\begin{tabular}{cc}
\hline Model Features & \\
\hline Location type & City Central Business District (CBD) \\
Height & $71.28 \mathrm{~m}$ \\
Volume & $106,920 \mathrm{~m}^{3}$ \\
Gross area & $27,000 \mathrm{~m}^{2}$ \\
Floor area & $1500 \mathrm{~m}^{2}$ \\
Floor height & $3.96 \mathrm{~m}^{(\mathrm{a})}$ \\
Opaque wall surface area & $11,404.80 \mathrm{~m}^{2}$ \\
Glazed wall surface area & $4561.92 \mathrm{~m}^{2}$ \\
Shape coefficient & 0.12 \\
\hline
\end{tabular}

The building model baseline is $50 \times 30 \mathrm{~m}$ and rectangular-shaped, with 18 floors above grade, representing a total height of $71.28 \mathrm{~m}$. The opaque envelope resorts to a "mass" type with concrete finishing (concrete material emissivity coefficient $(\varepsilon)=0.85$ [59]) with a "medium" envelope heat capacity. The glazed envelope is evenly distributed along the four sides with a 0.4 window-to-wall ratio [49] with interior adjustable blinds. The wider facades face east-west following prior cited studies. The model's envelope parameters (U-values and SHGC) depend on the building location (varies according to the simulated CZ) and follow Bai and Wang's research on the "public building model" [60] (p. 713, Table 2) (see Tables 4 and 5 below). 
Table 4. Summary of the BEM simulated envelope characteristics according to GB 50176-2016 climate zones specifications, following Bai and Wang's [60] (p. 713, Table 2) assessment.

\begin{tabular}{|c|c|c|c|c|}
\hline \multirow{2}{*}{ Climate Zone GB 50176-2016 [48] } & \multirow{2}{*}{$\begin{array}{c}\text { Roof } \\
\text { U-Value }\left(\mathrm{W} / \mathrm{m}^{2} \cdot \mathrm{K}\right)\end{array}$} & \multirow{2}{*}{$\begin{array}{c}\text { Wall } \\
\text { U-Value }\left(W / \mathrm{m}^{2} \cdot \mathrm{K}\right)\end{array}$} & \multicolumn{2}{|c|}{ Window } \\
\hline & & & U-Value $\left(\mathrm{W} / \mathrm{m}^{2} \cdot \mathrm{K}\right)$ & SHGC \\
\hline Severe cold (SCZ) A, B & 0.28 & 0.38 & 1.90 & 0.70 \\
\hline Severe cold (SCZ) C & 0.35 & 0.43 & 2.00 & 0.70 \\
\hline Cold (CZ) & 0.45 & 0.50 & 2.20 & 0.70 \\
\hline Hot summer and cold winter (HSCWZ) & 0.50 & 0.80 & 2.40 & 0.40 \\
\hline Hot summer and warm winter (HSWWZ) & 0.80 & 1.50 & 2.70 & 0.40 \\
\hline Mild (MZ) & 0.80 & 1.50 & 2.70 & 0.40 \\
\hline \multicolumn{5}{|c|}{$\begin{array}{l}\text { Note: Due to the Cove.tool's software inability to attribute different U-values to each glazed surface, the resear } \\
\text { team adopted a conservative stance by choosing the lower U-value for each CZ. } \\
\text { Table 5. Summary of the BEM baseline simulated systems and schedules according to Feng et al. [4 } \\
\text { (pp. 4-131, 4-132) and Feng and Levine [56] (pp. 7-8). }\end{array}$} \\
\hline \multicolumn{5}{|c|}{ Model Systems and Schedules } \\
\hline $\begin{array}{r}\text { Lig } \\
\text { Plug }\end{array}$ & $\begin{array}{r}\text { HVAC heating syste } \\
\text { HVAC cooling syste } \\
\text { HVAC distribution sys } \\
\text { Chiller COP (b) } \\
\text { Boiler efficiency (b) } \\
\text { Pumps } \\
\text { hting power density (L } \\
\text { nd equipment's power } \\
\text { Occupation density } \\
\text { Air tightness (b) } \\
\text { Outdoor air rate } \\
\text { Heating setpoint } \\
\text { Heating setback } \\
\text { Cooling setpoint } \\
\text { Cooling setback }\end{array}$ & $\begin{array}{l}\text { (b) } \\
\text { sity (b) }\end{array}$ & $\begin{array}{c}\text { Gas-fired boiler } \\
\text { ter-cooled centrifugal } \\
\text { vith hot water reheatir } \\
5.2 \\
0.89 \\
\text { Variable speed } \\
9 \mathrm{~W} / \mathrm{m}^{2} \\
15 \mathrm{~W} / \mathrm{m}^{2} \\
8 \mathrm{~m}^{3} / \mathrm{person}^{2} \\
3 \mathrm{~m}^{3} /\left(\mathrm{m}^{2} \mathrm{~h}\right) \\
20^{\circ} \mathrm{C} \\
5^{\circ} \mathrm{C} \\
26^{\circ} \mathrm{C} \\
37^{\circ} \mathrm{C}\end{array}$ & $\begin{array}{l}\text { ler } \\
\text { oil (a) }\end{array}$ \\
\hline
\end{tabular}

(a) Reheating only in CZ and SCZ climates [56] (p. 7). (b) Under GB 50189-2015 law.

In addition to the model's baseline (Tables $3-5$ and Figure 2 above), the research considered the inputs of key parameters to achieve a higher precision level, such as the occupants' metabolic rate of 1.1 (sitting and typing) [61] (p. 6, Table 5.2.1.2); no daylight and occupancy sensors; building automation and control system (BACS) standard Class C according to the EN 15232-1 standard (EN 15232-1 “Energy Performance of Buildings - Impact of Building Automation, Controls and Building Management" 2017; more information at https: / / www.en-standard.eu/din-en-15232-1-energy-performance-of-buildings-part-1impact-of-building-automation-controls-and-building-, accessed on 15 March 2021); 100\% mechanical ventilation (heating and cooling), with a MERV8/M5 or equivalent filtration system [62] (p. 29); enabled DCV; and 40\% recirculated exhausted air. The SWH comprises a 1 135.62-L (300 gals) tank fueled by a natural-gas-fired boiler (SWH device COP $=4.00$ [58] (p. 192) with a setpoint temperature of $60^{\circ} \mathrm{C}$, as described by PNNL-ASHRAE's prototype "Large Office" building model package [57] (Sec. DOE Building Description). These parameters are fundamental to fulfill the overall assessment. For instance, telework policies reduce the number of occupants (workers and non-workers), which contributes to heat internal gains, whose emissivity is calculated through the metabolic rate. Similarly, measures related to air rate manipulation, BACS, lighting, and filtration systems are also mentioned, with plausible expected impact on overall EUI. These key parameters are manually inserted in the Cove.tool interface "envelope features", "schedules", and "systems" tabs. 
In the second step, the BEM geometric features and the model orientation are loaded into Cove.tool through a SketchUp plugin (model geometric features import tutorial at https: / / www.cove.tools / sketchup-plugin, accessed on 29 April 2021). In the third step, the Cove.tool interface allows selecting the building type (office building), thermal code (ASHRAE-IECC Equivalent Energy Code standards), and location (Cove.tool collects climate data from the nearest weather station to the selected location for simulation purposes). Concerning the latter, to cover the majority of the Chinese territory, we selected the most populous city per CZ for simulation purposes according to the World Population Review [63] (see Table 6 below). Due to the current Chinese GB 50176-2016 CZ being often considered outdated and too coarse [48,64], our research follows Bai et al.'s [48] updated meteorological data that framed new Chinese CZ applying the ASHRAE standard 169-2013 method for CZ classification (see Table 6). This allows for simulating the BEM performance in 17 locations (cities), each one representative of a CZ. Each location is simulated in the baseline pre-C19 and both post-C19 78\% and 84\% scenarios.

Table 6. Simulated location features per CZ according to Bai et al.'s ASHRAE classification [48] (p. 12), [63].

\begin{tabular}{|c|c|c|c|c|c|c|}
\hline Zone & Subzone & Classification & City, Province & Population & Latitude (b) & Elevation (b) \\
\hline Zone 1 & A & very hot-humid & Haikou, Hainan & 615,835 & 20.04623 & $11 \mathrm{~m}$ \\
\hline Zone 2 & A & hot-humid & $\begin{array}{l}\text { Guangzhou, } \\
\text { Guangdong }\end{array}$ & $11,071,424$ & 23.13019 & $23 \mathrm{~m}$ \\
\hline \multirow{2}{*}{ Zone 3} & A & warm-humid & Shanghai, Shanghai & $22,315,474$ & 31.28732 & $4 \mathrm{~m}$ \\
\hline & $\mathrm{C}$ & warm-humid-highland & Kunming, Yunnan & $3,855,346$ & 24.88430 & $1932 \mathrm{~m}$ \\
\hline \multirow{3}{*}{ Zone 4} & A & mixed-humid & Xi'an, Shaanxi & $6,501,190$ & 34.34305 & $377 \mathrm{~m}$ \\
\hline & $\mathrm{B}$ & mixed-dry & Beijing, Beijing & $11,716,620$ & 39.90621 & $46 \mathrm{~m}$ \\
\hline & $\mathrm{H}$ & mixed-highland & Chamdo, Xizang (a) & 44,028 & 31.14497 & $3250 \mathrm{~m}$ \\
\hline \multirow{3}{*}{ Zone 5} & A & cool-humid & Shenyang, Liaoning & $6,255,921$ & 41.67498 & $47 \mathrm{~m}$ \\
\hline & $\mathrm{B}$ & cool-dry & Lanzhou, Gansu & $2,628,426$ & 36.06207 & $1528 \mathrm{~m}$ \\
\hline & $\mathrm{H}$ & cool-highland & Lhasa, Xizang & 118,721 & 29.65538 & $3658 \mathrm{~m}$ \\
\hline \multirow{3}{*}{ Zone 6} & A & cold-humid & Changchun, Jilin & $4,193,073$ & 43.81307 & $216 \mathrm{~m}$ \\
\hline & $\mathrm{B}$ & cold-dry & Ordos, Nei Menggu & $1,940,653$ & 39.60814 & $1308 \mathrm{~m}$ \\
\hline & $\mathrm{H}$ & cold-highland & Xi'ning, Qinghai & 767,531 & 36.61733 & $2268 \mathrm{~m}$ \\
\hline \multirow{2}{*}{ Zone 7} & - & very cold & Harbin, Heilongjiang & $5,878,939$ & 45.79882 & $118 \mathrm{~m}$ \\
\hline & $\mathrm{H}$ & very cold-highland & Delinghá, Qinghai (a) & 54,844 & 37.36908 & $2992 \mathrm{~m}$ \\
\hline \multirow{2}{*}{ Zone 8} & - & subarctic & Tahé, Heilongjiang (a) & 81,480 & 52.32526 & $358 \mathrm{~m}$ \\
\hline & $\mathrm{H}$ & subarctic-highland & Yushu, Qinghai & 124,736 & 33.00060 & $3695 \mathrm{~m}$ \\
\hline
\end{tabular}

(a) 2010 survey accessed in Brinkoff [65]; (b) accessed in www.maps.ie, accessed on 29 April 2021.

The fourth step introduces the energy-related data in the "envelope features", "schedules", and "systems" Cove.tool interface tabs. These data inputs vary considering the specifications of the pre- and post-COVID-19 scenarios or locations (see detailed inputs in the next Section 2.1 and Schemes A1 and A2). From this point forward, Cove.tool performs a year-round energy simulation in the specified location. In the fifth and final step, and after each simulation, the software generates a quantitative data report on the building's overall EUI and "cooling", "heating", "lighting", "plugs and equipment", "pumps", "SWH EUI", and " $\mathrm{CO}_{2}$ emissions". The reports are further analyzed into the following fields: annual usable energy consumption, $\mathrm{CO}_{2} \mathrm{e}$, and energy costs.

\subsection{Pre- and Post-COVID-19 Scenario Descriptions}

The goal is to run three simulations under the model baseline features of a standard office building operation in China in each location. The scenario before the COVID-19 pandemic arises (pre-C19) corresponds to the previously described BEM baseline. The 
scenarios posterior to the COVID-19 pandemic are referred as "post-C19 78\%" and "postC19 84\%".

\subsubsection{BACS and Sensors}

In the post-C19 scenarios, BACS is upgraded to class B (advanced BACS and TBM, according to EN 15232:2017-Energy Performance of Buildings-Impact of Building Automation, Controls and Building Management), allowing for remote control and automation as suggested by ASHRAE [16] (p. 11). To prevent direct control by users (touch on surfaces), light and blind switches were deactivated and replaced by automatic daylight and occupancy sensors following ASHRAE recommendations $[16,66]$. The BACS upgrade optimizes the HVAC system, applying a 0.80 and 0.93 efficiency factor for thermal and electrical energy, respectively, with the consequent effect on the building energy consumption [67].

\subsubsection{Air Rate}

The COVID-19 guidelines primarily pursue HVAC strategies that increase outdoor airflow while reducing recirculated air to a bare minimum $[5,8,9,14]$. In other words, for post-C19 scenarios, the research team adopted a combination of natural and mechanical ventilation as suggested by ASHRAE [16] (p. 64) and CAR under climate assessment [8] and a reduction in indoor air recirculation to a maximum of $20 \%$, assuring a fresh air volume higher than $40 \%$, as mentioned by Guo et al. [5] (p. 6) and recommended by CAR [8]. In the same way, during non-occupancy periods, disabling the demand-controlled ventilation (DCV) becomes critical to ensure indoor air dilution, which demands the highest possible values of outdoor air [68]. Concerning this matter, the research team increased the outdoor air rate value per person from $30 \mathrm{~m}^{3} / \mathrm{h}$ to $36 \mathrm{~m}^{3} / \mathrm{h}(10 \mathrm{~L} / \mathrm{s})$ as suggested by WHO [9] (p. 11), [69], and set an additional pre- and post-occupancy hour of outside air flush schedule on workdays, following CAR's recommendations $[8,13]$.

\subsubsection{Ambient Temperature and Relative Humidity}

The optimal indoor conditions to inactivate the virus are similar to typical indoor human comfort values [70]. The HR should be maintained within $40 \%$ to $60 \%$ to minimize the risk of infection [16,71]. Simultaneously, the indoor AT should range between $20^{\circ} \mathrm{C}$ and $25^{\circ} \mathrm{C}$ with minor variations [70] (p. 11), similar to those considered in the pre-C19 scenario. High AT and HR values decrease the virus's life cycle, and dropping them has the opposite effect while increasing its infectiousness [72]. According to Guo et al. [5] (p. 6), Chinese guidelines for HVAC systems recommend increasing the air supply for heating setpoint temperature and decreasing for cooling. For these reasons, the research team kept the pre-C19 heating and cooling setpoint values for working hours. Still, during non-occupied hours, the heating setback changes from $5{ }^{\circ} \mathrm{C}$ to $16^{\circ} \mathrm{C}$ (the minimum recommended value by CAR [8] and ASC [13] for indoor AT is $16^{\circ} \mathrm{C}$ to $18^{\circ} \mathrm{C}$ ) to avoid a drastic temperature drop in cold to very cold climates, thus decreasing the virus's survival odds.

\subsubsection{Filtration}

According to CAR, another post-C19 measure oversees the filtration system update [5] up to the F7 standard or above [8]. The research team started with a MERV 8/M5 baseline filter, upgrading it to MERV 14/F8, which produces an increased airflow resistance from $77.22 \mathrm{~Pa}$ (0.31 in.w.g.) to $169.38 \mathrm{~Pa}(0.68$ in.w.g.), respectively [71] (pp. 6, 10) (considering a $24 \times 24 \times 2$ in. pleated panel filter in MERV 8, and a $24 \times 24 \times 12$ in. pleated microglass medium with aluminum separators in MERV 14 [71] (pp. 6, 10)), and consequently escalating the energy consumption for "fans" (see Table 7 below). When compared with the pre-C19 scenario, it adds an extra 5918.64 Wh of energy consumption, calculated according to the following formula [73] (number 4):

$$
P=d p \cdot q /\left(\mu_{f} \cdot \mu_{b} \cdot \mu_{m}\right)
$$


where $\mathrm{P}=$ power consumption $(\mathrm{W}) ; \mathrm{q}=$ air volume delivered $\left(\mathrm{m}^{3} / \mathrm{s}\right) ; \mathrm{dp}=$ total pressure (Pa.); $\mu_{\mathrm{f}}=$ fan efficiency; $\mu_{\mathrm{b}}=$ belt efficiency; $\mu_{\mathrm{m}}=$ motor efficiency.

Brendel [74] (p. 16) stated that a standard AHU single-fan system exhibits a minimum efficiency of 0.6 under 5 in.w.g. on a motor power of $1.3 \mathrm{hp} / \mathrm{kCFM}$. The research considered an efficiency value of 0.87 for a $10 \mathrm{~kW}$ motor and 0.88 for the belt [73] (number 4).

Table 7. Fan power energy consumption.

\begin{tabular}{|c|c|c|}
\hline & Pre-C19 (MERV8) & Post-C19 (MERV14) \\
\hline Air volume delivered $\left(\mathrm{m}^{3} / \mathrm{h} \cdot\right.$ person $)$ & 0.00833 & 0.01 \\
\hline Number of occupants (a) & 13,365 & 6683 \\
\hline Total air volume delivered $(\mathrm{q})\left(\mathrm{m}^{3} / \mathrm{s}\right)$ & 111,371 & 66,825 \\
\hline Filter max. initial resistance $(\mathrm{dp})(\mathrm{Pa})(\mathrm{b})$ & 77.22 & 169.38 \\
\hline Fan efficiency $\left(\mu_{\mathrm{f}}\right)(\mathrm{c})$ & \multicolumn{2}{|c|}{0.6} \\
\hline Belt efficiency $\left(\mu_{\mathrm{b}}\right)(\mathrm{c})$ & \multicolumn{2}{|c|}{0.88} \\
\hline Motor efficiency $\left(\mu_{\mathrm{m}}\right)(\mathrm{c})$ & \multicolumn{2}{|c|}{0.87} \\
\hline Power consumption $\left(P=d p \cdot q /\left(\mu_{\mathrm{f}} \cdot \mu_{\mathrm{b}} \cdot \mu_{\mathrm{m}}\right)\right)(\mathrm{W})$ & $18,721.77$ & $24,640.41$ \\
\hline Power consumption diff. (MERV 14/F8 -MERV 8/M5) (W) & \multicolumn{2}{|c|}{5918.64} \\
\hline Fan operation on working days (hour/yr) (d) & \multicolumn{2}{|c|}{3380} \\
\hline \multicolumn{3}{|l|}{ Additional two-hour air flush (weekdays) (e) } \\
\hline Number of hours per year & \multicolumn{2}{|c|}{520} \\
\hline Power consumption $(\mathrm{W} / \mathrm{yr})$ & \multicolumn{2}{|c|}{$12,813,012.93$} \\
\hline \multicolumn{3}{|l|}{ Additional fan power consumption } \\
\hline$(\mathrm{kW} / \mathrm{yr})$ & \multicolumn{2}{|c|}{$31,818.00$} \\
\hline$\left(\mathrm{kW} / \mathrm{m}^{2} \mathrm{yr}\right)$ & \multicolumn{2}{|c|}{1.22} \\
\hline
\end{tabular}

(a) $8 \mathrm{~m}^{3}$ /person $\times$ building volume (pre-C19) and $16 \mathrm{~m}^{3} /$ person $\mathrm{x}$ building volume (post-C19). (b) MERV8 $24 \times 24 \times 2$ in. pleated panel filter, and a MERV14 $24 \times 24 \times 12$ in. pleated micro-glass medium with aluminum separators [71] (pp. 6, 10). (c) Fan efficiency $=0.6$ [74]; motor $(10 \mathrm{~kW})$ efficiency $=0.87$ and belt $(10 \mathrm{~kW})$ efficiency $=0.88$ [73]. (d) 13 working hours (7 a.m.-8 p.m.). (e) Two-hour outside air flush (before and after occupation on working days).

Some guidelines recommend using UVGI $[5,13,69]$ as a supplement to natural ventilation strategies [30]. These are based on "upper-room" (air) UVGI devices used to disinfect the air near the ceiling area of indoor compartments and "in-duct" devices placed to eliminate microbiological agents within the HVAC systems [21]. However, some Chinese institutions' guidelines, like the CCTG, advise against "in-duct" UVGI systems, thus demanding further studies in this matter [13].

The upper-air UVGI devices' effectiveness to decrease viral transmission raises consensual opinions [30,75] even when compared with other UVGI applications, such as "in-duct" or air handling [21].

Regarding energy consumption, both Riley and Nardell [76] and Martin et al. [77] point toward an energy value of $30 \mathrm{~W}$ (nominal input) per $18.58 \mathrm{~m}^{2}$ of indoor space to inactivate the virus in medical facilities. In other sources, the US HHS-CDC guideline for mitigating tuberculosis with UVGI devices [78] (p. VIII) refers to a value of $1.83 \mathrm{~W} / \mathrm{m}^{2}$ or $6.36 \mathrm{~W} / \mathrm{m}^{3}$ for compartments with ceiling height around $2.4 \mathrm{~m}$. Moreover, for upper-room installations, Kerkhoff and Dijk [79] (p. 26) suggests a ratio of 0.2 to $0.5 \mathrm{~W} / \mathrm{m}^{2}$ for various microorganisms, a value lower than the US HHS-CDC reference of $1.61 \mathrm{~W} / \mathrm{m}^{2}$. Considering the authors above, in the post-C19 scenarios, the research team adopted a conservative posture and added to the BEM general lighting schedule ( $7 \mathrm{am}$ to $8 \mathrm{pm}$ ) a Philips UV-C TUV T8 $55 \mathrm{~W}$ HO lamp type [79] with a UV-C light power density of $1.83 \mathrm{~W} / \mathrm{m}^{2}$ [78] (p. VIII). 
When it comes to SHW, a temperature value lower than $60^{\circ} \mathrm{C}\left(140{ }^{\circ} \mathrm{F}\right)$ increases virus manifestation probability [29]. Due to this, the research team kept the previously stated value with no impact on energy consumption in this field.

\subsubsection{Remote Work Policies}

Following the McKinsey report forecast on telework for China, the post-C19 scenarios contemplate a 22\% (post-C19 78\%) and a 16\% (post-C19 84\%) cut on building occupancy [41] (Exhibit 3, theoretical maximum and effective potential). This recommendation increases the available space per person during working hours (Chinese standard building prototype and energy code does not mention occupation values for non-working hours), from the initial $8 \mathrm{~m}^{3}$ to $9.52 \mathrm{~m}^{3}$ (84\% occupation) and $10.26 \mathrm{~m}^{3}$ (78\% occupation).

\subsubsection{Summary}

Tables 8 and 9 summarize the differences between pre-C19 and post-C19 scenarios in "schedules" and "systems" inputs.

Table 8. Summary of Cove.tool schedules inputs in pre- and post-C19 scenarios.

\begin{tabular}{|c|c|c|}
\hline Schedule Inputs & Pre-C19 & Post-C19 \\
\hline Daylight sensors & No & Yes (a) \\
\hline Occupancy sensors & No & Yes (a) \\
\hline Lighting (LPD) & $9 \mathrm{~W} / \mathrm{m}^{2}$ & $10.83 \mathrm{~W} / \mathrm{m}^{2}(\mathrm{~b})$ \\
\hline Lighting (unocccup. h) (LPD) & \multicolumn{2}{|c|}{$\mathrm{n} / \mathrm{a}$} \\
\hline Lighting (exterior) & \multicolumn{2}{|c|}{$\mathrm{n} / \mathrm{a}$} \\
\hline Plug-equipment (PA) & \multicolumn{2}{|c|}{$15 \mathrm{~W} / \mathrm{m}^{2}$} \\
\hline Plug-equipment (PA) (unoccup. h) & \multicolumn{2}{|c|}{$\mathrm{n} / \mathrm{a}$} \\
\hline Metabolic rate & \multicolumn{2}{|c|}{ 1.1 Met (sitting and typing) } \\
\hline Heating setpoint & \multicolumn{2}{|c|}{$20.00{ }^{\circ} \mathrm{C}$} \\
\hline Heating setback & $5^{\circ} \mathrm{C}$ & $16^{\circ} \mathrm{C}(\mathrm{c})$ \\
\hline Cooling setpoint & \multicolumn{2}{|c|}{$26^{\circ} \mathrm{C}$} \\
\hline Cooling setback & \multicolumn{2}{|c|}{$37^{\circ} \mathrm{C}$} \\
\hline Total occupants (occup. h) & $8 \mathrm{~m}^{3} /$ person & $\begin{array}{c}9.52 \mathrm{~m}^{3} / \text { person }(\mathrm{d}) \\
10.26 \mathrm{~m}^{3} / \text { person }(\mathrm{e})\end{array}$ \\
\hline Total occupants (unoccup. h) & \multicolumn{2}{|c|}{$\mathrm{n} / \mathrm{a}$} \\
\hline
\end{tabular}

Table 9. Summary of Cove.tool systems inputs in pre- and post-C19 scenarios.

\begin{tabular}{cc}
\hline Systems Inputs & Pre-C19 \\
\hline HVAC system type: heating & Gas-fired boiler \\
\hline HVAC system type: cooling & Water-cooled centrifugal chillers \\
\hline HVAC system distribution & VAV terminal box with damper and hot water reheating coil \\
\hline Integrated part load value & Constant speed centrifugal chiller \\
\hline Heating system COP & 0.89 \\
\hline Cooling system COP & 5.2 \\
\hline Heat recovery system & Run-around coil \\
\hline Fan flow control factor & Variable speed \\
\hline
\end{tabular}


Table 9. Cont.

\begin{tabular}{ccc}
\hline Systems Inputs & Pre-C19 & Post-C19 \\
\hline Specific fan power & Central mechanical ventilation with heating and cooling \\
\hline Ventilation type & Mechanical & Natural and mechanical (a) \\
\hline People outdoor air rate (per person) & $30 \mathrm{~m}^{3} / \mathrm{h}(8.33 \mathrm{~L} / \mathrm{s})$ & $\mathrm{n} / \mathrm{a} \mathrm{m}^{3} / \mathrm{h}(10 \mathrm{~L} / \mathrm{s})(\mathrm{a})$ \\
\hline Area outdoor air rate & $3.00 \mathrm{~m}^{3} / \mathrm{h}_{\text {hfloor area }}$ \\
\hline Infiltration & Advanced (class B) (b) & Disabled (a) \\
\hline BACS & Standard (class C) & $20 \%$ \\
\hline DCV (ventilation control) & Demand control & Natural gas \\
\hline Exhaust recirculation & 1135.62 litters tank \\
\hline SWH system fuel & $60{ }^{\circ} \mathrm{C}$ \\
\hline SWH system capacity & min $80 \%$ \\
\hline SWH system performance efficiency & Gas boiler, HR boiler \\
\hline SWH generation & Circulation system (0.6)
\end{tabular}

(a) Natural ventilation and outdoor air rate increase strategies. (b) BACS upgrade recommendations. (c) Cove.tool calculated.

\subsection{Reliability}

The BES methodology acquires its reliability with the BEM qualities and is designed to simulate the Chinese standard office building's energy performance across several locations in different CZ. The literature review shows that BES methodology is frequently applied to assess buildings' energy performances in studies with purposes similar to our research [32,52]. The adopted prototype, developed by Feng et al. [49] and Feng and Levine [56], follows the PNNL-ASHRAE prototype building model methodology, upheld by the US Department of Energy. Regarding the locations, instead of using the GB 50176-2016 CZ, the research resorts to Bai et al.'s [48] climate classification based on the ASHRAE standard 169-2013 method. As a result, the simulated locations grew from 11 to 17 , increasing the precision and volume of outcome data. The methodology simplicity is the key factor to achieve the desired reliability: data inputs are entered on a BEM through a software interface built to simulate an office building operating in different scenarios. The process repeats itself by adapting the data delivered by the COVID-19 pandemic mitigation measures and telework prediction figures endorsed by several entities. Despite Cove.tool software not relying on dynamic simulation analysis, it follows the EN 15603 (EN 15603:2008 - energy performance of buildings, overall energy use and definition of energy ratings) and ISO 13790 (ISO 13790:2008 - energy performance of buildings, calculation of energy use for space heating and cooling) energy calculation methodology [80], generating outcomes within 5\% of EnergyPlus (more information at https:/ / energyplus.net/, accessed on 16 March 2021) for office buildings [55]. Additionally, this tool is ready-made and optimized to use the ASHRAE standard data and settings, which have been widely applied and studied by the Chinese scientific community in this field.

\section{Results}

\subsection{Data Analysis}

The following data and interpretations concern the relative values between pre- and post-C19 scenario outcomes. The reports raw data are available on Appendix B.1, from Scheme A1 to Figure A51. 


\subsubsection{Energy Consumption}

Overall, the assessment reveals an increase in EUI after implementing the postpandemic mitigation measures (see Table 10 and Scheme 1 below). The energy consumption rises progressively toward northern latitudes and/or colder climates in post-C19 scenarios for both occupancy figures, confirming an energy overconsumption trend (see Scheme 1 below, "linear" trend lines). However, in "very hot" to "hot-humid" climates, the energy consumption decreases in both occupancy scenarios. Lower building occupation rates tend to increase energy consumption in colder climates while reducing it in warmer ones. For more information see Appendix B, Tables A3 and A4.

Table 10. Usable energy consumption per location in pre- and post-C19 scenarios.

\begin{tabular}{|c|c|c|c|c|}
\hline \multirow[b]{2}{*}{ CZ, City, Province } & \multicolumn{2}{|c|}{ Usable Energy Consumption (kWh/m² $\mathbf{y r})$} & \multicolumn{2}{|c|}{ Variation Difference } \\
\hline & Pre-C19 & $\begin{array}{l}\text { Post-C19 } \\
78 \% \mid 84 \%\end{array}$ & $\begin{array}{c}\text { Absolute Value } \\
\left(\mathrm{kWh} / \mathrm{m}^{2} \mathrm{yr}\right) \\
78 \% \mid 84 \%\end{array}$ & $\begin{array}{c}\text { Percentual (\%) } \\
78 \% \mid 84 \%\end{array}$ \\
\hline Zone 1-A, Haikou, Hainan & 98.21 & $82.38 \mid 82.23$ & $-15.83 \mid-14.98$ & $-16.12 \mid-15.25$ \\
\hline Zone 2-A, Guangzhou, Guangdong & 95.14 & $81.04 \mid 81.56$ & $-14.10 \mid-13.58$ & $-14.82 \mid 14.27$ \\
\hline Zone 3-A, Shanghai, Shanghai & 163.45 & $172.24 \mid 170.65$ & $8.79 \mid 7.20$ & $5.38 \mid 4.41$ \\
\hline Zone 3-C, Kunming, Yunnan & 102.93 & $104.73 \mid 103.50$ & $1.80 \mid 0.57$ & $1.75 \mid 0.55$ \\
\hline Zone 4-A, Xi'an, Shaanxi & 245.82 & $267.61 \mid 265.64$ & $21.79 \mid 19.82$ & $8.86 \mid 8.06$ \\
\hline Zone 4-B, Beijing, Beijing & 329.42 & $365.60 \mid 363.35$ & $36.18 \mid 33.93$ & $10.98 \mid 10.30$ \\
\hline Zone 4-H, Chamdo, Xizang & 338.10 & $378.72 \mid 374.97$ & $40.62 \mid 36.87$ & $12.01 \mid 10.91$ \\
\hline Zone 5-A, Shenyang, Liaoning & 490.19 & $585.48 \mid 582.63$ & $95.29 \mid 92.44$ & $19.44 \mid 18.86$ \\
\hline Zone 5-B, Lanzhou, Gansu & 340.39 & $388.16 \mid 385.41$ & $47.77 \mid 45.02$ & $14.03 \mid 13.23$ \\
\hline Zone 5-H, Lhasa, Xizang & 313.71 & $344.94 \mid 341.49$ & $31.23 \mid 27.78$ & $9.96 \mid 8.86$ \\
\hline Zone 6-A, Changchun, Jilin & 690.03 & $810.44 \mid 807.32$ & $120.41 \mid 117.29$ & $17.45 \mid 17.00$ \\
\hline Zone 6-B, Ordos, Nei Menggu & 487.07 & $555.10 \mid 551.82$ & $68.03 \mid 64.75$ & $13.97 \mid 13.29$ \\
\hline Zone 6-H, Xi'ning, Qinghai & 485.99 & $542.56 \mid 538.84$ & $56.57 \mid 52.85$ & $11.64 \mid 10.87$ \\
\hline Zone 7, Harbin, Heilongjiang & 756.78 & $887.51 \mid 884.37$ & $130.73 \mid 127.59$ & $17.27 \mid 16.86$ \\
\hline Zone 7-H, Delinghá, Qinghai & 572.99 & $641.86 \mid 637.96$ & $68.87 \mid 64.97$ & $12.02 \mid 11.34$ \\
\hline Zone 8, Tahé, Heilongjiang & 1091.27 & $1319.64 \mid 1315.84$ & $228.37 \mid 224.57$ & $20.93 \mid 20.58$ \\
\hline Zone 8-H, Yushu, Qinghai & 561.96 & $625.34 \mid 620.63$ & $63.38 \mid 58.67$ & $11.28 \mid 10.44$ \\
\hline
\end{tabular}

The gap between pre- and post-C19 trend "lines" becomes wider toward colder CZ (zones 6 to 8 ). This translates the impact of the guidelines, increasing the usable energy consumption from Zone 3-A-Shanghai to Zone 8-H-Yushu on average between 12.46\%, or $67.94 \mathrm{kWh} / \mathrm{m}^{2} \mathrm{yr}$ (post-C19 78\%), and $11.70 \%$, or $-57.29 \mathrm{kWh} / \mathrm{m}^{2} \mathrm{yr}$ (post-C19 84\%). For southern locations, the "very hot" and "hot-humid" climates of Haikou and Guangzhou (Zone 1-A and 2-A) see a drop in energy consumption, consuming less at rates from 16.12\% (post-C19 78\%) to $15.25 \%$ (post-C19 84\%), and 14.82\% (post-C19 78\%) to $14.27 \%$ (post-C19 $84 \%$ ), respectively, when compared to the pre-C19 scenario.

Conversely, a standard office building located in Kunming (zone 3-C, "warm-humid highland") displays the lowest variation between scenarios, consuming, on average, an extra $1.75 \%$ (post-C19 78\%) and 0.55\% (post-C19 84\%). A building located in the highlands (Chamdo, Lhasa, Xi'ning, Delinghá, and Yushu) increases its energy consumption between $8.86 \%$ and $12.02 \%$. Despite being in different CZ, these results align with the "average" increasing value.

The post-C19 78\% outcomes display higher values in the savings of southern locations and northern overconsumption when compared to post-C19 $84 \%$ for all CZ.

The flotation of absolute values between pre- and post-C19 can be grouped by the following order (see Scheme 1):

- Orange dashed line- "very hot" and "hot" climates from Zone 1-A to 2-A: average reduction amount between $14.97 \mathrm{kWh} / \mathrm{m}^{2} \mathrm{yr}$ (post-C19 78\%) and $14.28 \mathrm{kWh} / \mathrm{m}^{2} \mathrm{yr}$ (post-C19 84\%); 
- $\quad$ Red dashed line- “warm" to "mixed humid" climates from Zone 3-A to 4-A: average increase amount between $10.79 \mathrm{kWh} / \mathrm{m}^{2} \mathrm{yr}$ (post-C19 78\%) and $9.20 \mathrm{kWh} / \mathrm{m}^{2} \mathrm{yr}$ (postC19 84\%);

- Green dashed line-_"mixed-dry" to "cool" climates from Zone 4-A to 5-H: average increase value amount $45.48 \mathrm{kWh} / \mathrm{m}^{2} \mathrm{yr}$ (post-C19 78\%) and $42.64 \mathrm{kWh} / \mathrm{m}^{2} \mathrm{yr}$ (postC19 84\%);

- Blue dashed line-_"cold" to "subarctic" climates from Zone 6-A to 8-H: average increase amount between $105.19 \mathrm{kWh} / \mathrm{m}^{2} \mathrm{yr}$ (post-C19 78\%) and $101.53 \mathrm{kWh} / \mathrm{m}^{2} \mathrm{yr}$ (post-C19 84\%).

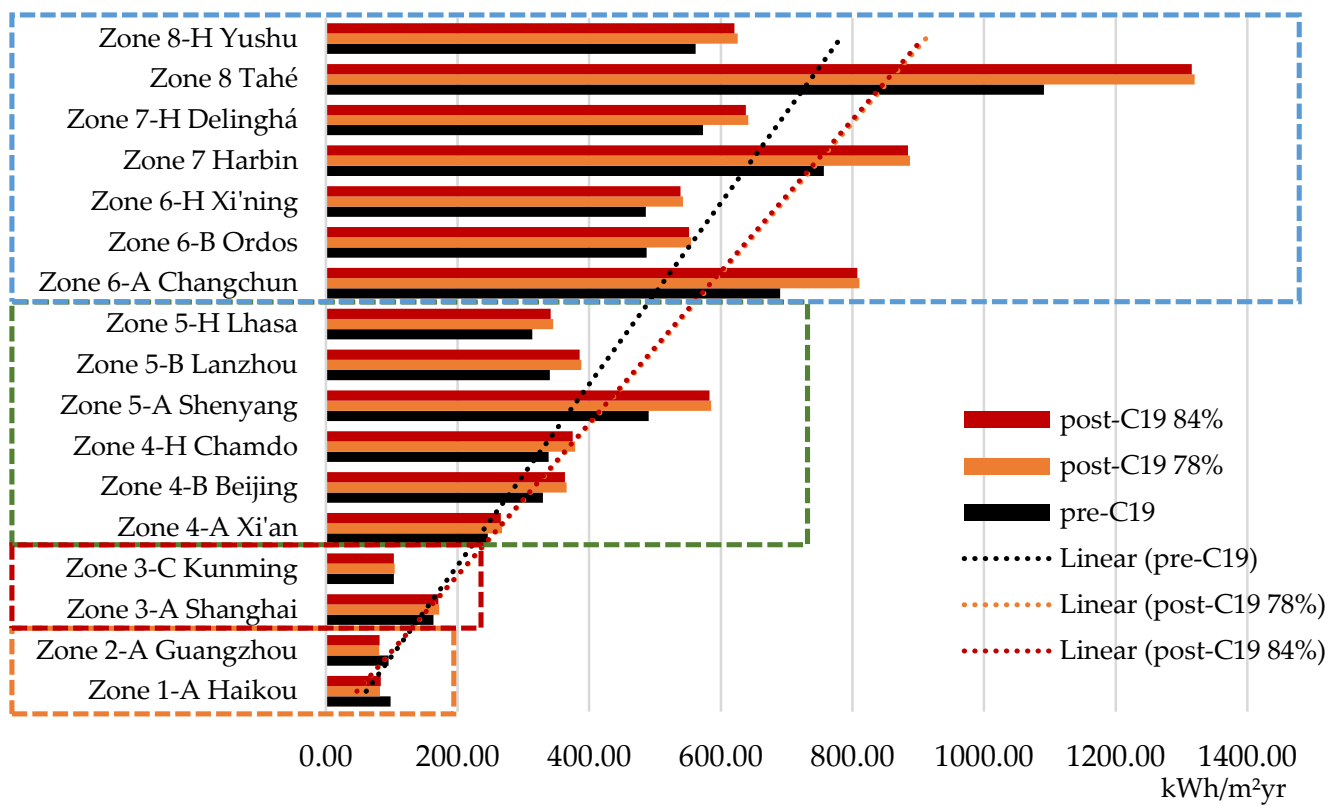

Scheme 1. Usable energy consumption per location in pre- and post-C19 scenarios.

As the climate becomes colder and the latitude increases, the gap in absolute values for both scenarios is more significant. To exemplify this, a building located in Tahé (Zone 8 "subarctic") displays the highest value, consuming an extra $228.37 \mathrm{kWh} / \mathrm{m}^{2} \mathrm{yr}$ (post-C19 $78 \%$ ) and $224.57 \mathrm{kWh} / \mathrm{m}^{2} \mathrm{yr}$ (post-C19 84\%) of energy followed by Harbin and Changchun (Zone 7 "very-cold" and 6-A "cold-humid", respectively). However, the same building located in Shanghai or Kunming (Zone 3-A, 3-C "warm-humid-highland") shows the lowest figure, consuming, at most, $8.79 \mathrm{kWh} / \mathrm{m}^{2} \mathrm{yr}$ and $1.80 \mathrm{kWh} / \mathrm{m}^{2} \mathrm{yr}$ more, respectively (see Table 10 above).

The "cooling" and "heating" EUI differ according to the location climatic features (see Table 11 and Scheme 2 below). In the post-C19 scenarios, locations with "very hot" to "hot-humid" climates, such as Haikou and Guangzhou (Zone 1-A and 2-A), reach an average "cooling" EUI of $17.57 \%$ of the total EUI with non-expressive heating demand values ( $\leq 2 \%$ of the EUI). On the contrary, from "warm" to "subarctic" climates (Zone 3-A to 8-H), the "heating" EUI becomes gradually significant, being on average $76.64 \%$ of the total EUI and reaching $87.77 \%$ on Tahé (Zone 8 "subarctic") (see Scheme 2 below). In these locations, the "cooling" EUI weight is marginal (0.65\% on average). 
Table 11. Cooling and heating EUI per location in pre- and post-C19 scenarios.

\begin{tabular}{|c|c|c|c|c|c|c|}
\hline \multirow{2}{*}{ CZ, City, Province } & \multicolumn{2}{|c|}{$\begin{array}{c}\text { Cooling } \\
\left(\mathrm{kWh} / \mathrm{m}^{2} \mathrm{yr}\right)\end{array}$} & \multicolumn{2}{|c|}{$\begin{array}{c}\text { Heating } \\
\left(\mathrm{kWh} / \mathrm{m}^{2} \mathrm{yr}\right)\end{array}$} & \multicolumn{2}{|c|}{$\begin{array}{c}\text { Variation Difference } \\
(\%)\end{array}$} \\
\hline & Pre-C19 & $\begin{array}{l}\text { Post-C19 } \\
78 \% \mid 84 \%\end{array}$ & Pre-C19 & $\begin{array}{l}\text { Post-C19 } \\
78 \% \mid 84 \%\end{array}$ & $\begin{array}{l}\text { Cooling } \\
78 \% \mid 84 \%\end{array}$ & $\begin{array}{l}\text { Heating } \\
78 \% \mid 84 \%\end{array}$ \\
\hline Zone 1-A, Haikou, Hainan & 20.36 & $15.34 \mid 15.93$ & 0.00 & $0.00 \mid 00$ & $-24.66 \mid-21.76$ & $0.00 \mid 0.00$ \\
\hline Zone 2-A, Guangzhou, Guangdong & 16.76 & $12.57 \mid 13.05$ & 1.21 & $1.27 \mid 1.15$ & $-25.00 \mid-22.14$ & $4.96 \mid-4.96$ \\
\hline Zone 3-A, Shanghai, Shanghai & 8.38 & $5.90 \mid 6.18$ & 78.52 & $96.50 \mid 94.65$ & $-29.59 \mid-26.25$ & $22.90 \mid 20.54$ \\
\hline Zone 3-C, Kunming, Yunnan & 1.52 & $0.58 \mid 0.66$ & 28.47 & $38.92 \mid 37.64$ & $-61.84 \mid-56.58$ & $36.71 \mid 32.21$ \\
\hline Zone 4-A, Xi'an, Shaanxi & 8.32 & $6.10 \mid 6.36$ & 156.52 & $186.33 \mid 184.18$ & $-26.68 \mid-23.56$ & $19.05 \mid 16.67$ \\
\hline Zone 4-B, Beijing, Beijing & 7.80 & $5.40 \mid 5.66$ & 235.73 & $277.96 \mid 275.58$ & $-30.77 \mid-27.44$ & $17.91 \mid 16.90$ \\
\hline Zone 4-H, Chamdo, Xizang & 0.04 & $0.01 \mid 0.01$ & 254.27 & $297.83 \mid 294.32$ & $-75.00 \mid-75.00$ & $17.13 \mid 15.75$ \\
\hline Zone 5-A, Shenyang, Liaoning & 5.26 & $3.38 \mid 3.58$ & 391.62 & $484.74 \mid 481.86$ & $-35.74 \mid-31.94$ & $23.78 \mid 23.04$ \\
\hline Zone 5-B, Lanzhou, Gansu & 3.13 & $1.44 \mid 1.60$ & 252.38 & $303.53 \mid 300.79$ & $-53.99 \mid-48.88$ & $20.27 \mid 19.18$ \\
\hline Zone 5-H, Lhasa, Xizang & 0.07 & $0.02 \mid 0.02$ & 231.13 & $266.19 \mid 262.91$ & $-71.43 \mid-71.43$ & $15.17 \mid 13.75$ \\
\hline Zone 6-A, Changchun, Jilin & 2.84 & $1.37 \mid 1.51$ & 583.78 & $697.08 \mid 694.05$ & $-51.76 \mid-46.83$ & $19.41 \mid 18.89$ \\
\hline Zone 6-B, Ordos, Nei Menggu & 1.56 & $0.62 \mid 0.70$ & 392.96 & $460.93 \mid 457.80$ & $-60.26 \mid-55.13$ & $17.30 \mid 16.50$ \\
\hline Zone 6-H, Xi'ning, Qinghai & 0.07 & $0.01 \mid 0.02$ & 393.07 & $451.62 \mid 448.13$ & $-85.71 \mid-71.43$ & $14.90 \mid 14.01$ \\
\hline Zone 7, Harbin, Heilongjiang & 3.16 & $1.54 \mid 1.69$ & 646.59 & $768.00 \mid 764.95$ & $-51.27 \mid-46.52$ & $18.78 \mid 18.31$ \\
\hline Zone 7-H, Delinghá, Qinghai & 0.04 & $0.01 \mid 0.01$ & 474.53 & $542.55 \mid 538.88$ & $-75.00 \mid-75.00$ & $14.33 \mid 13.56$ \\
\hline Zone 8 Tahé, Heilongjiang & 0.81 & $0.26 \mid 0.30$ & 968.39 & $1171.56 \mid 1167.96$ & $-67.90 \mid-62.96$ & $20.98 \mid 20.61$ \\
\hline Zone 8-H, Yushu, Qinghai & 0.00 & $0.00 \mid 0.00$ & 465.47 & $528.72 \mid 524.27$ & $0.00 \mid 0.00$ & $13.59 \mid 12.63$ \\
\hline
\end{tabular}

The post-pandemic scenarios induce an average "cooling" EUI energy reduction between $48.62 \%$ or $1.50 \mathrm{kWh} / \mathrm{m}^{2} \mathrm{yr}$ (post-C19 $78 \%$ ) and $44.87 \%$ or $1.34 \mathrm{kWh} / \mathrm{m}^{2} \mathrm{yr}$ (postC19 84\%), considering all locations. Haikou and Guangzhou (Zones 1-A and 2-A) display the highest impact on absolute values, consuming, respectively, $15.34-15.93 \mathrm{kWh} / \mathrm{m}^{2} \mathrm{yr}$ and $12.57-13.05 \mathrm{kWh} / \mathrm{m}^{2} \mathrm{yr}$ less of energy. Meanwhile, Yushu (Zone 8-H) does not require cooling loads, and the highlands (Zone 4-H, 5-H, 6-H, 7-H) display the lowest "cooling" EUI, consuming less than $0.02 \mathrm{kWh} / \mathrm{m}^{2} \mathrm{yr}$ despite the average $75.00 \%$ variation decrease. Similarly, in "mixed" to "subarctic" climates (Zone 4-A, 4-B, 5-A, 5-B, 6-A, 6-B, 7, and 8), besides the percentual variation drop (less $45.10 \%$ on average), the absolute value lowers when compared to locations from "very hot" to "warmer", such as Zones 1-A and 2-A (average of $1.52 \mathrm{kWh} / \mathrm{m}^{2} \mathrm{yr}$ vs. $4.34 \mathrm{kWh} / \mathrm{m}^{2} \mathrm{yr}$ ) (see Table 11).

The Zone 1-A Haikou does require "heating" EUI loads; however, the same parameter increases in Zone 2-A Guangzhou on post-C19 78\% by $4.96 \%$ and the opposite trend on post-C19 $84 \%$ by the exact figure. In the remaining locations, the research team observed a steady increase in "heating" EUI, on average, of $19.48 \%$ or $67.94 \mathrm{kWh} / \mathrm{m}^{2} \mathrm{yr}$ (post-C19 $78 \%$ ), and $18.24 \%$ or $64.97 \mathrm{kWh} / \mathrm{m}^{2} \mathrm{yr}$ (post-C19 84\%) (see Scheme 2 and Table 11 above).

Overall, from Xian (Zone 4-A "mixed-humid") into colder locations, a progressive increase in the difference between "heating" EUI absolute values pre- and post-C19 scenarios is seen (except Lanzhou (Zone 5-B "cool-dry") and the "highlands" locations) (see Scheme 2), hence the extra energy consumed. To exemplify this, a building located in Tahé (Zone 8 "subarctic") exhibits the highest difference, meaning an additional consumption of $199.57 \mathrm{kWh} / \mathrm{m}^{2} \mathrm{yr}$ (post-C19 78\%) to $203.17 \mathrm{kWh} / \mathrm{m}^{2} \mathrm{yr}$ (post-C19 84\%). However, for Shanghai (Zone 3-A "warm-humid"), the same difference drops to an extra value of $16.13 \mathrm{kWh} / \mathrm{m}^{2} \mathrm{yr}$ (post-C19 78\%) to $17.98 \mathrm{kWh} / \mathrm{m}^{2} \mathrm{yr}$ (post-C19 84\%).

Considering EUI fans, the buildings located in Zone 1-A Haikou and 2-A Guangzhou have a reduced average of $8.21 \%$. The remaining locations registered a "fans" EUI increase average between $28.57 \%$ (post-C19 78\%) and 27.99\% (post-C19 84\%). Overall, the research team identifies a common trend: fans EUI tend to increase with post-C19 measures. Nonetheless, this behavior tends to increase the percentage difference in colder climates or higher latitudes (except the "highlands" locations) (see Table A1). 
Regarding the EUI "lighting", the average decreases to $47.62 \%\left(8.88 \mathrm{kWh} / \mathrm{m}^{2} \mathrm{yr}\right)$ with minor deviations under post-C19 scenarios considering all locations (see Table A2). The plug equipment, pumps, and "SWH" EUI did not change in the post-C19 scenarios.

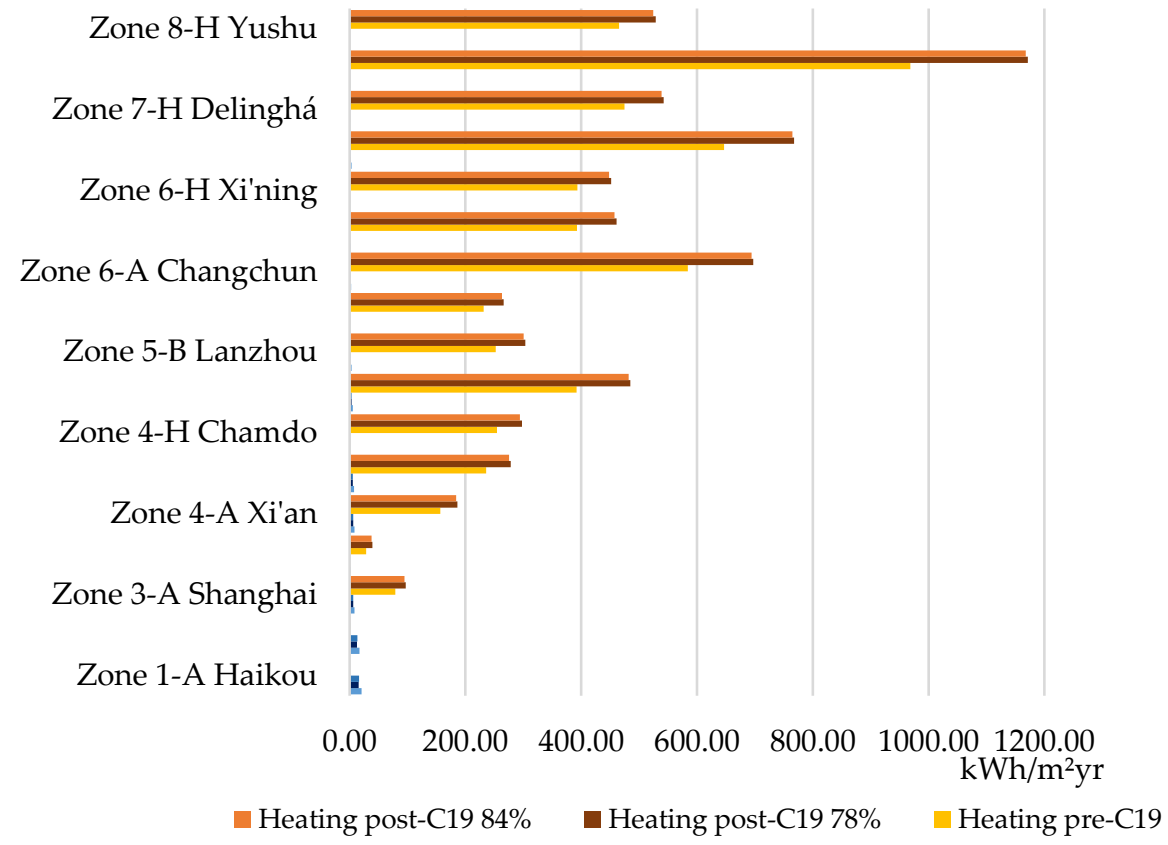

Scheme 2. Cooling and heating EUI per location in pre- and post-C19 scenarios.

\subsection{2. $\mathrm{CO}_{2}$ Emissions}

The research team observes a correlation between the amount of usable energy consumed by the building and the $\mathrm{CO}_{2} \mathrm{e}$ in post-C19 scenarios (see Scheme 2 above and Scheme 3 below).

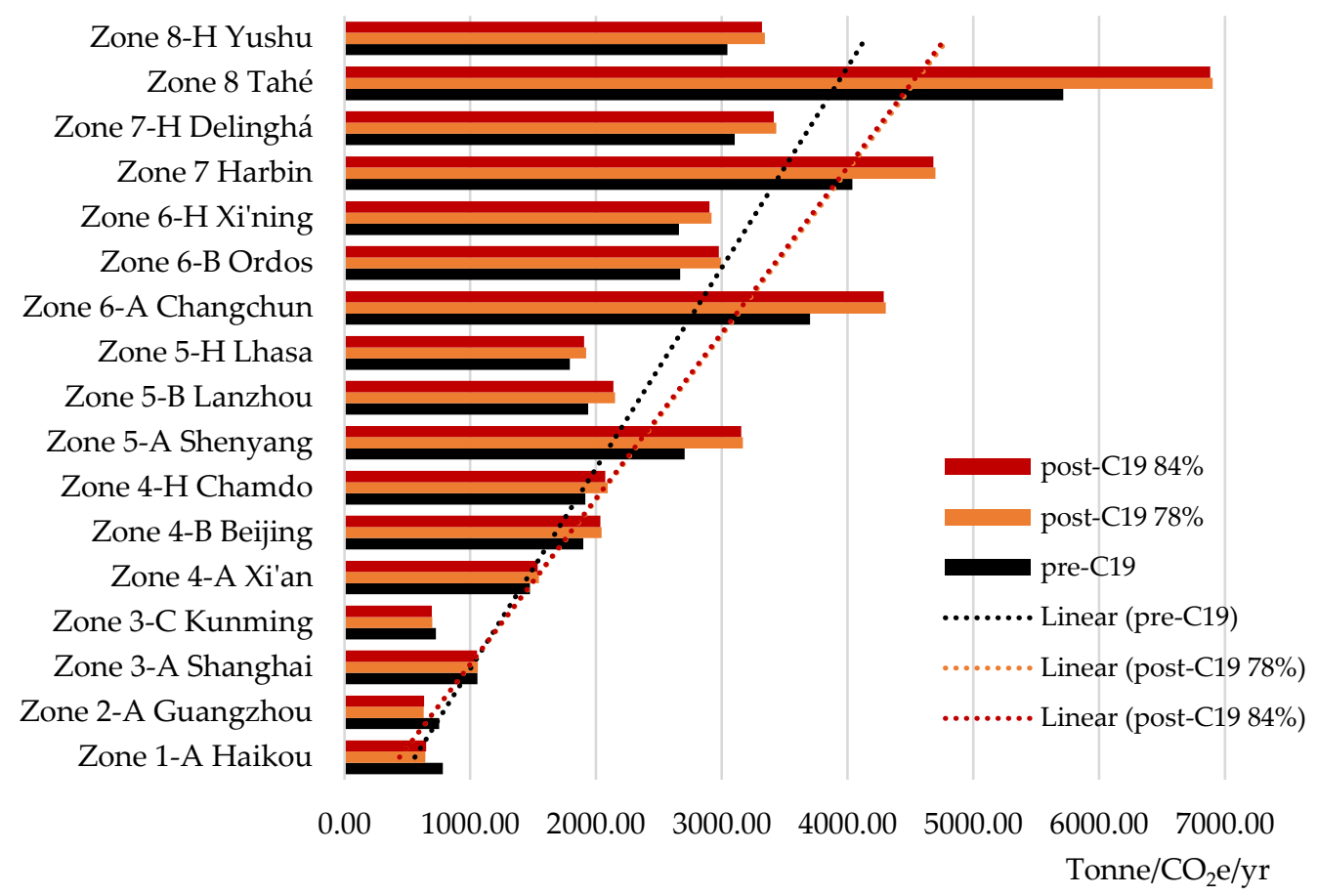

Scheme 3. $\mathrm{CO}_{2}$ e comparison per location in pre- and post-C19 scenarios. 
The "linear" trend shows an overall increase in $\mathrm{CO}_{2} \mathrm{e}$ with post-C19 scenarios in all locations except Zone 1-A Haikou to 3-C Kunming, with higher impact toward colder regions (see Scheme 3, linear lines gap). The outcomes show a steady increase in $\mathrm{CO}_{2} \mathrm{e}$ from Zone 3-C Kunming to 8-H Yushu, on average, by $11.76 \%$ or 374.04 tonne $/ \mathrm{CO}_{2} \mathrm{e} / \mathrm{yr}$ (post-C19 78\%), to $11.13 \%$ or 357.76 tonne/ $\mathrm{CO}_{2} \mathrm{e} / \mathrm{yr}$ (post-C19 84\%).

On the contrary, in the "very hot-humid" to "warm" climates of Zone 1-A to 3-C, there is a $\mathrm{CO}_{2}$ e reduction range around 9\%, reaching $17.73 \%$ (post-C19 78\%) and 16.86\% (post-C19 84\%) in Zone 1-A Haikou. The lowest variations occur in the "mixed" climates of Zone 3-C to 4-B with an average $\mathrm{CO}_{2} \mathrm{e}$ increased value between $2.28 \%$ (post-C19 78\%) and $1.62 \%$ (post-C19 84\%), while the highest is observed in the "subarctic" Zone 8 Tahé (see Table 12 below).

Table 12. $\mathrm{CO}_{2}$ emissions per location in pre- and post-C19 scenarios.

\begin{tabular}{|c|c|c|c|c|}
\hline \multirow[b]{2}{*}{ CZ, City, Province } & \multicolumn{2}{|c|}{$\mathrm{CO}_{2}$ Emissions (Tonne/ $\mathrm{CO}_{2} \mathrm{e} / \mathrm{yr}$ ) } & \multicolumn{2}{|c|}{ Variation Difference } \\
\hline & Pre-C19 & $\begin{array}{l}\text { Post-C19 } \\
78 \% \mid 84 \%\end{array}$ & $\begin{array}{c}\text { Absolute Value } \\
78 \% \text { | } 84 \%\end{array}$ & $\begin{array}{c}\text { Percentual (\%) } \\
78 \% \mid 84 \%\end{array}$ \\
\hline Zone 1-A, Haikou, Hainan & 781.80 & $643.20 \mid 650.00$ & $-138.60 \mid-131.8$ & $-17.73 \mid-16.86$ \\
\hline Zone 2-A, Guangzhou, Guangdong & 752.90 & $628.10 \mid 632.80$ & $-124.80 \mid-120.10$ & $-16.58 \mid-15.95$ \\
\hline Zone 3-A, Shanghai, Shanghai & 1057.50 & $1060.70 \mid 1053.90$ & $3.20 \mid-3.60$ & $0.30 \mid-0.34$ \\
\hline Zone 3-C, Kunming, Yunnan & 725.70 & $698.50 \mid 692.70$ & $-27.20 \mid-33.00$ & $-3.75 \mid-4.55$ \\
\hline Zone 4-A, Xi'an, Shaanxi & 1474.20 & $1544.80 \mid 1535.80$ & $70.60 \mid 61.60$ & $4.79 \mid 4.18$ \\
\hline Zone 4-B, Beijing, Beijing & 1897.10 & $2044.30 \mid 2033.80$ & $147.20 \mid 136.70$ & $7.76 \mid 7.21$ \\
\hline Zone 4-H, Chamdo, Xizang & 1913.90 & $2092.90 \mid 2073.80$ & $179.00 \mid 159.90$ & $9.35 \mid 8.35$ \\
\hline Zone 5-A, Shenyang, Liaoning & 2704.90 & $3167.70 \mid 3153.90$ & $462.80 \mid 449.00$ & $17.11 \mid 16.60$ \\
\hline Zone 5-B, Lanzhou, Gansu & 1938.60 & $2151.10 \mid 2137.70$ & $212.50 \mid 199.10$ & $10.96 \mid 10.27$ \\
\hline Zone 5-H, Lhasa, Xizang & 1790.50 & $1920.80 \mid 1903.50$ & $130.30 \mid 113.00$ & $7.28 \mid 6.31$ \\
\hline Zone 6-A, Changchun, Jilin & 3700.10 & $4301.70 \mid 4286.10$ & $601.60 \mid 586.00$ & $16.26 \mid 15.84$ \\
\hline Zone 6-B, Ordos, Nei Menggu & 2668.90 & $2991.70 \mid 2975.10$ & $322.80 \mid 306.20$ & $12.09 \mid 11.47$ \\
\hline Zone 6-H, Xi'ning, Qinghai & 2659.70 & $2918.80 \mid 2900.90$ & $259.10 \mid 241.20$ & $9.74 \mid 9.07$ \\
\hline Zone 7, Harbin, Heilongjiang & 4039.10 & $4698.30 \mid 4682.70$ & $659.20 \mid 643.60$ & $16.32 \mid 15.93$ \\
\hline Zone 7-H, Delinghá, Qinghai & 3102.90 & $3432.20 \mid 3412.40$ & $329.30 \mid 309.50$ & $10.61 \mid 9.97$ \\
\hline Zone 8, Tahé, Heilongiiang & 5714.90 & $6902.70 \mid 6883.60$ & $1187.80 \mid 1168.70$ & $20.78 \mid 20.45$ \\
\hline Zone 8-H, Yushu, Qinghai & 3042.50 & $3342.80 \mid 3318.19$ & $300.30 \mid 276.40$ & $9.87 \mid 9.08$ \\
\hline
\end{tabular}

Despite the different climate types in the "highlands", these locations show similar higher values, ranging from 7.28\% (post-C19 78\%) to 6.21\% (post-C19 84\%) in Zone 5-H Lhasa to 10.61\% (post-C19 78\%) and 9.97\% (post-C19 84\%) in Zone 7-H Delinghá.

When it comes to absolute values, a building located in the cold regions of Harbin (Zone 7 "very-cold") and Tahé (Zone 8 "subarctic") displays the highest potential to increase $\mathrm{CO}_{2} \mathrm{e}-$ more 659.2 tonne $/ \mathrm{CO}_{2} \mathrm{e} / \mathrm{yr}$ (post-C19 78\%) and 643.6 tonne $/ \mathrm{CO}_{2} \mathrm{e} / \mathrm{yr}$ (post-C19 $84 \%$ ), to 1187.8 tonne $/ \mathrm{CO}_{2} \mathrm{e} / \mathrm{yr}$ (post-C19 78\%) and 1168.70 tonne $/ \mathrm{CO}_{2} \mathrm{e} / \mathrm{yr}$ (post-C19 $84 \%$ ), respectively. The "very hot" to "hot" climates of Haikou and Guangzhou (Zone 1-A, 2-A) show the highest decrease under post-C19 scenarios (see Table 12).

\subsubsection{Energy Costs}

The average prices for natural gas and electricity in China depend on the oversees provinces (electrical industrial power rates prices for $10 \mathrm{kv}$ per Chinese province according to Zhang [81] (Sec. "China's electricity pricing by region”); natural gas prices per Chinese province according to Paltsev and Zhang [82] (p. 11). Based on the studied locations, the electricity price of the $\mathrm{kWh}$, on average, costs $65.28 \%$ more than natural gas.

The research team concluded a correlation between the total energy consumed, $\mathrm{CO}_{2} \mathrm{e}$, and cost behavior (see Schemes 1 and 3 above and Scheme 4 below). The overall annual expense increases in both post-C19 scenarios with an inflection point in Zone 3-C Kunming. For more information see Appendix B, Table A5. 


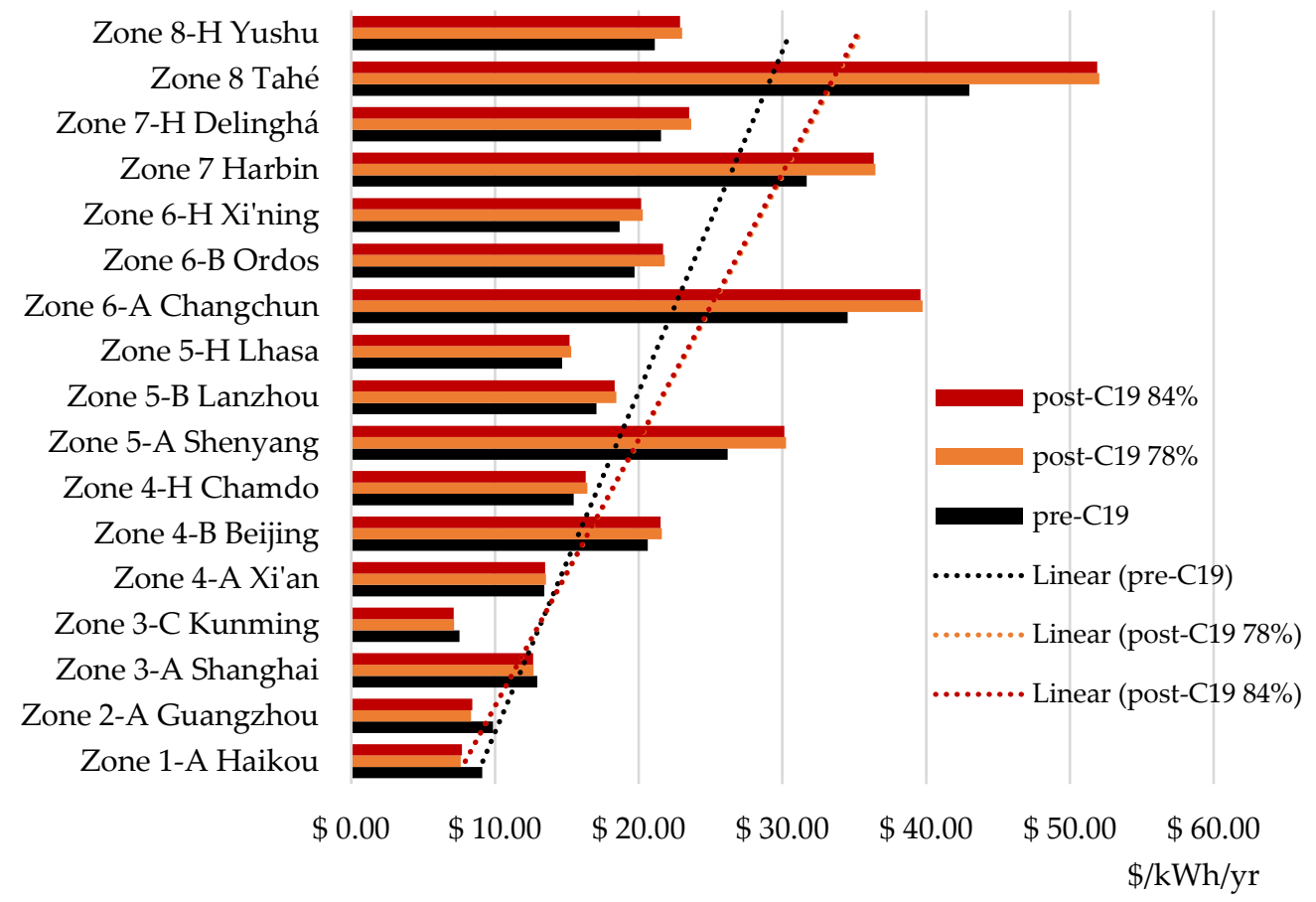

Scheme 4. Energy costs (USD) per location in pre- and post-C19 scenarios.

There is a steady increasing trend in the operation costs of buildings (from the "mixed" Zone 4-A Xi'an to the "subarctic highland" Zone 8-H Yushu (on average, 9.89\% in post-C19 $78 \%$, and $9.37 \%$ in post-C19 84\%), averaging an additional USD $2.68 \mathrm{kWh} / \mathrm{yr}$ (post-C19 78\%) and USD $2.57 \mathrm{kWh} / \mathrm{yr}$ (post-C19 84\%) (see Scheme 4 above, linear trend lines). A building located in Zone 8 Tahé sees its annual energy costs rise between $21.03 \%$ or USD $9.04 \mathrm{kWh} / \mathrm{yr}$ (post-C19 78\%), and 20.72\% or USD $8.91 \mathrm{kWh} / \mathrm{yr}$ (post-C19 84\%), when compared with the pre-C19 scenario; this is followed by Zone 7 Harbin and Zone 6-A Changchun. The lowest variation occurs in Zone 4-A Xi'an (average extra cost of $0.06 \mathrm{kWh} / \mathrm{yr}$ ) and Zone 5-H Lhasa (average extra cost of USD $0.56 \mathrm{kWh} / \mathrm{yr}$ ) in the post-C19 84\% scenario.

In warmer climates, from Zone 1-A Haikou to 3-C Kunming, it is possible to cut costs by $16.66 \%$, or USD $1.52 \mathrm{kWh} / \mathrm{yr}$ (post-C19 78\%) and 15.76\%, or USD $1.44 \mathrm{kWh} / \mathrm{yr}$ (post-C19 84\%). On average, in warmer to hot climates, the costs reduce by $9.77 \%$ or USD 0.92 (post-C19 78\%), and $9.64 \%$ or USD $0.91 \mathrm{kWh} / \mathrm{yr}$ (post-C19 84\%).

\subsection{Findings and Comments}

The previous section comprises the following key findings:

- A correlation between the amount of usable energy consumed by the building emitting $\mathrm{CO}_{2}$ and costs behavior in post-C19 scenarios;

- An overall increase in buildings' usable energy consumption in 15 of the 17 simulated locations, for latitudes above $24^{\circ} \mathrm{N}$ ("warm" to "subarctic" climates) at an average rate of $12.46 \%$ (post-C19 78\%) and $11.70 \%$ (post-C19 84\%) in post-C19 scenarios;

- The usable energy consumption of lower latitudes under $24^{\circ} \mathrm{N}$ ("hot" to "very hot" climates) is cut by, on average, between $15.47 \%$ (post-C19 78\%) and 14.76\% (post-C19 $84 \%)$;

- "Cooling" and "heating" play a decisive role due to their EUI weight. In particular, the last one displays with an average EUI weight of $76.64 \%$, peaking at $87.77 \%$ on Tahé (Zone 8 "subarctic");

- The acclimatization, mainly the "heating" field, has a considerable impact on the building's overall performance (energy consumption, $\mathrm{CO}_{2} \mathrm{e}$, and costs) in post-C19 scenarios; 
- The "lighting" and "fans" EUI consumption are marginal compared to other assessed parameters;

- Remote work policies also impact a building's energy performance, assuming the extra space for establishing safe distancing between workers and visitors, and;

- The lower the occupation figure, the higher the energy consumption in cold climates (harmful) and the lower in hot to warm ones (beneficial).

\section{Discussion}

The research addresses the impact of COVID-19 guidelines on office buildings' energy performances in the post-pandemic era across China's territory. The authors analyzed the main guidelines published and focused on the Chinese entities CAR, CCTG, PMPH, and CDCP. After identifying the most targeted parameters (ventilation and social distancing), the Feng et al. [56] Chinese office building prototype model was assessed under three scenarios: pre-C19 baseline and post-C19 with $78 \%$ and $84 \%$ occupation [41]. Resorting to a BES methodology, the research measured and evaluated the EUI, $\mathrm{CO}_{2} \mathrm{e}$, and energy operating costs of a BEM located in $8 \mathrm{CZ}$ and 17 subzones following Bai et al.'s [48] CZ classification. In post-C19 scenarios, the outcomes show an overall increasing tendency in the studied energy-related fields as we move toward colder climates ("warm" to "subarctic") and energy savings in "hot" to "very hot" locations. The acclimatization, mainly the "heating" field, has a considerable impact on the overall performance due to its average $76.64 \%$ EUI weight (from "warm" to "subarctic") and the tendency to aggravate in colder climates. Due to the remote work policies, occupation cuttings are beneficial in warmer climates and harmful in cold ones. Moreover, the outcomes show that the lower the occupation value, the higher the impact. Recommendations related to filtration upgrades, such as MERV 8/M5 to 14/F8 [8,22] and UVGI installment [13,21], prove to be non-relevant, in absolute numbers, for the building performance despite their EUI variations. The results can be explained by measures such as the open-window policy, the increase in outdoor air-rates per person, pre- and post-occupancy air-flush, DCV disabling, and air recirculation reduction that tend to increase "fans" and "heating" EUI [28] due to the increment of energy lost due to "ventilation". Simultaneously, increasing the AT from $5{ }^{\circ} \mathrm{C}$ to $16^{\circ} \mathrm{C}$ during non-working hours with less occupancy ( $16 \%$ to $22 \%$ cut) contributes to an overall energy increase (mainly heating). These adjustments are particularly harmful to the building performance in colder climates and higher latitudes due to the "heating" EUI weight. This means that any recommendation that affects this field plays a decisive role in energy savings or expenditure. On the contrary, with less internal heating gains, natural ventilation strategies in place (leading to passive cooling), DCV disabling, and higher airflow rates, the "cooling" EUI drops in "hot" to "very hot" locations.

The research confirms the literature forecast that COVID-19 guidelines directly impact the energy consumption in an office building during annual operation. Nonetheless, despite the lack of quantitative figures, the literature points toward an overall increase in energy consumption $[16,21-24,29]$. This study partially corroborates the prior authors but only in 15 locations, from Zone 3-A Shanghai to Zone 8-H Yushu ("warm" to "subarctic" climates). In a country already facing climate change consequences [64], the guideline recommendations go against future expectations by increasing the $\mathrm{CO}_{2} \mathrm{e}$ and energy-related costs in 13 locations (Zone 4-A Xi'an to Zone 8-H Yushu) in post-C19 scenarios. To a certain extent, these outcomes align with literature expectations that advocate for an escalation in HVAC systems operation costs $[16,21,36]$, although these are not observable in warmer regions. Cortiços and Duarte [32] achieved similar results in the USA, realizing that energy demand does not show a homogenous behavior when comparing pre- and post-COVID-19 scenarios in different locations. However, the USA analysis shows higher figures, with the usable energy consumption rising, on average, by $21.72 \%$ in cold climates versus the $12.46 \% / 11.70 \%$ achieved in the current research on Chinese territory. Nonetheless, for "warm" to "very hot" climates, China delivers accountable savings with 16.12\%/15.25\% against the $11.92 \%$ in the USA. A plausible cause for the discrepancies, aside from geographic reasons, relates 
to the simulated office building prototype's features and indoor occupancy (50\% cut in the USA vs. $16 \%$ and $22 \%$ in our study). (Note that the USA research did not consider the telework forecasts but rather the COVID-19 recommendations.) Once more, and in line with our findings, the acclimatization EUI reflects, particularly for the "heating" parameter, an energy performance negative impact in cold climate locations. Similarly, Feng et al. [27] also refer to the fact that "cooling", "heating", and "fans" correspond to a weight EUI of $45.79 \%$, although this is limited to Beijing, Shanghai, and Guangzhou, cities that correspond to a climate classification of "mixed", "warm", and "hot-humid" in the current research, respectively. Other authors found the same overall increasing consumption tendency, such as Ascione et al. [28], Faulkner et al. [37], and Zheng et al. [20]. The last author concluded that prioritizing health over comfort or efficiency led to an energy consumption increase of $128 \%$ on a Chinese public building during the pandemic, which is over $100 \%$ higher than the highest value in our study (Zone 8 Tahé in Heilongjiang province). The assessed building type, location, and constructive features can explain the discrepancy in performance. By the same token, Kang et al.'s [33] study in South Korea during the pandemic concluded that the office building electricity rose (+)1.5\% from January to March 2020. This value is significantly lower than the current study outcomes but confirms the same upward tendency. However, according to this study, the year ended with an average of less, (-)1.36\%, due to lockdown enforcement (level 2) and shutting down the electronic equipment. Natural gas faced even more significant cuts, achieving a yearly average of $(-) 7.31 \%$ for reducing heating and hot water consumption, showing a contrasting tendency against the overconsumption claim. It is essential to acknowledge that energy consumption dropped during lockdowns and not when the economy reopened, a scenario similar to the post-C19 simulated in the current research. To support this claim, Si et al. [31] state that the power and gas sectors were some of the most affected by the COVID-19 pandemic, leading to negative supply over demand.

In the same way, Wang et al. [35], in 2021, found that electricity consumption dropped in China by (-)29\%, from January to August 2020, compared with the 2015 to 2019 period. With the reopening of the economy, the numbers flipped from savings to overconsumption. In line with our study, and showing a decreasing tendency in energy consumption, is the Gui et al. [34] research that states an energy consumption cut of around $24.88 \mathrm{kWh} / \mathrm{m}^{2}$ on HVAC systems during the academic year at five campuses at Griffith University, Southeast Queensland, Australia. The results are due to the lockdowns and Queensland's "humid subtropical" climate classification (Köppen-Geiger Climate Classification subtype "Cfa"Humid Subtropical Climate), showing an energy-saving trend in line with our study for "very hot" to "hot-humid" climates (Zone 1-A Haikou and 2-A Guangzhou).

Until now, publications were lacking that addressed the impact of telework or hybrid workplace predictions on energy consumption; therefore, the authors open the discussion to fill this gap. Mokhtari and Jahangir [38] presents a solid example run in a Tehran University that addresses the impact of occupant distribution under air exchange rate, class duration, and working-hours presets to achieve a balance between health and EE. Despite the differences (in location, building type, function, systems, and schedules), there is a similar acknowledgment in our research that indoor occupation has an impact by decreasing the infection odds and saving energy.

Finally, and in line with Awada et al. [26], the research team foresees that COVID-19 mitigation guidelines will not only push for indoor health and safety but also for new design, layouts, schedules, and systems (HVAC) in building operation and management.

\subsection{Contribution to Knowledge}

The authors recognize that COVID-19 guidelines mainly follow the settings of nursing homes and knowledge published by SBS authors, which from 1988 (120) to 2020 (558) increased production by $465 \%$ (according to Scopus). The guidelines underline the concerns of contemporary societies in achieving a healthier and safer environment in the workplace (e.g., indoor smoking bans) and, from an employer point of view, seeking higher produc- 
tivity and lower absenteeism [83]. They also recognize the Chinese research institutions' (e.g., CAR) efforts to design COVID-19 HVAC/AHU guidelines to tackle the EE and $\mathrm{CO}_{2} \mathrm{e}$ following international commitments, such as the Paris Accord, while improving indoor air quality. The research identifies an overall EUI's overconsumption trend, following other authors' recent studies [16,21-24,29], despite two southern locations revealing opposite outcomes. At last, higher ventilation rates remove the necessity of cooling loads in hot climates and improve air quality for users under post-C19 scenarios.

\subsection{Study Limitations}

The authors acknowledge the following limitations:

- Official guidelines to standard office buildings that set 0.4 window-to-wall ratios in every CZ [56];

- Non-official CZ in favor of a scientific update considering the climate changes;

- $\quad$ The sparse number of cities for each CZ;

- Limitations of the EE software (Cove.tool) that call for further calculations, such as fan airflow pressure and UV light consumption (manual input);

- The generalization of the standard Chinese office building following the official guidelines;

- $\quad$ The lack of involved costs to update the HVAC/AHU, BACS, installation of UVGI devices, sensors, and change the filters, and;

- Besides the sources referred to in the Literature section $[41,43,47]$, there is a lack of novel studies/reports forecasting China's telework weight tendency in the near future.

\section{Conclusions}

The research team took the effort to verify the disruption produced by the COVID-19 mitigation guidelines and telework prediction on Chinese office buildings in the coming future. The study followed a vastly used methodology framed by BES plus BEM and run under-recognized LEED software. It concluded, on the one hand, the results by the growth in EUI by $11.70 \%$ and $12.46 \%, \mathrm{CO}_{2}$ e by $11.13 \%$ and $11.76 \%$, and costs by $9.37 \%$ and $9.89 \%$, upon $78 \%$ and $84 \%$ occupation rate, respectively, for buildings located in "warm/mixed" to "subarctic" climates, which is more visible in colder regions with high heating demands. On the other hand, the figures for "very hot" to "hot/warm" climates are lower for EUI by $14.76 \%$ and $15.47 \%, \mathrm{CO}_{2}$ e by $9 \%$ (in both scenarios), and costs by $9.64 \%$ and $9.77 \%$, upon $78 \%$ and $84 \%$ occupation rate respectively, respectively. The study proves the reliability of simple models to predict the impact of new policies upon the studied energy parameters.

Today's policy designs struggle to address climate change as well as new social and working models, as the first imposes "new" CZ adjustments while the second imposes new ways of life toward health, safety, and changing working habits. The current indoor air guidelines need desegregation to address the "new" CZ as well as the social and working patterns to balance energy shortage, rising costs, and $\mathrm{CO}_{2} \mathrm{e}$. The path is open to introduce new technologies, such as real-time assessment based on envelope sensors and thermal cameras managed by self-learning HVAC/AHU systems. Together with artificial intelligence technology, these systems will manage and adjust in real-time the best indoor conditions [20] to tackle environmental disruptions and alert maintenance needs.

Author Contributions: C.C.D. oversaw conceptualization, methodology, software, validation, formal analysis, investigation, data curation, writing - original draft preparation, writing-review and editing, and visualization. N.D.C. oversaw conceptualization, validation, formal analysis, investigation, resources, data curation, writing — original draft preparation, writing - review and editing, project administration, funding acquisition, and supervision. All authors have read and agreed to the published version of the manuscript.

Funding: This research was funded by FCT—Fundação para a Ciência e Tecnologia, I.P., under the Strategic Project with the reference UIBD/04008/2020.

Institutional Review Board Statement: Not applicable. 
Data Availability Statement: Not applicable.

Acknowledgments: The authors acknowledge the support given by CIAUD—Research Centre for Architecture, Urbanism and Design, Lisbon School of Architecture, University of Lisbon, as well as the Cove.tool team for providing an educational version of the software and their ready assistance to help us pursue our research goals.

Conflicts of Interest: The authors declare no conflict of interest.

\section{Appendix A}

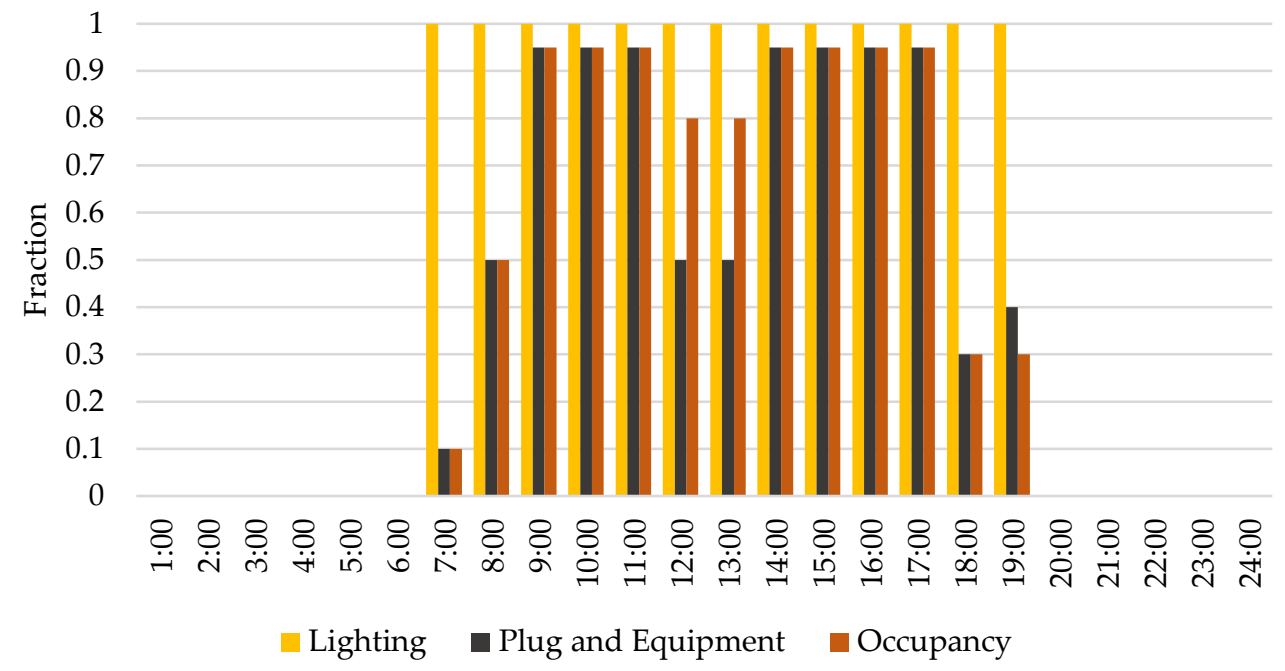

Scheme A1. Standard office building model schedules on weekdays by Feng et al. [49] (pp. 4-125, Figure 4).

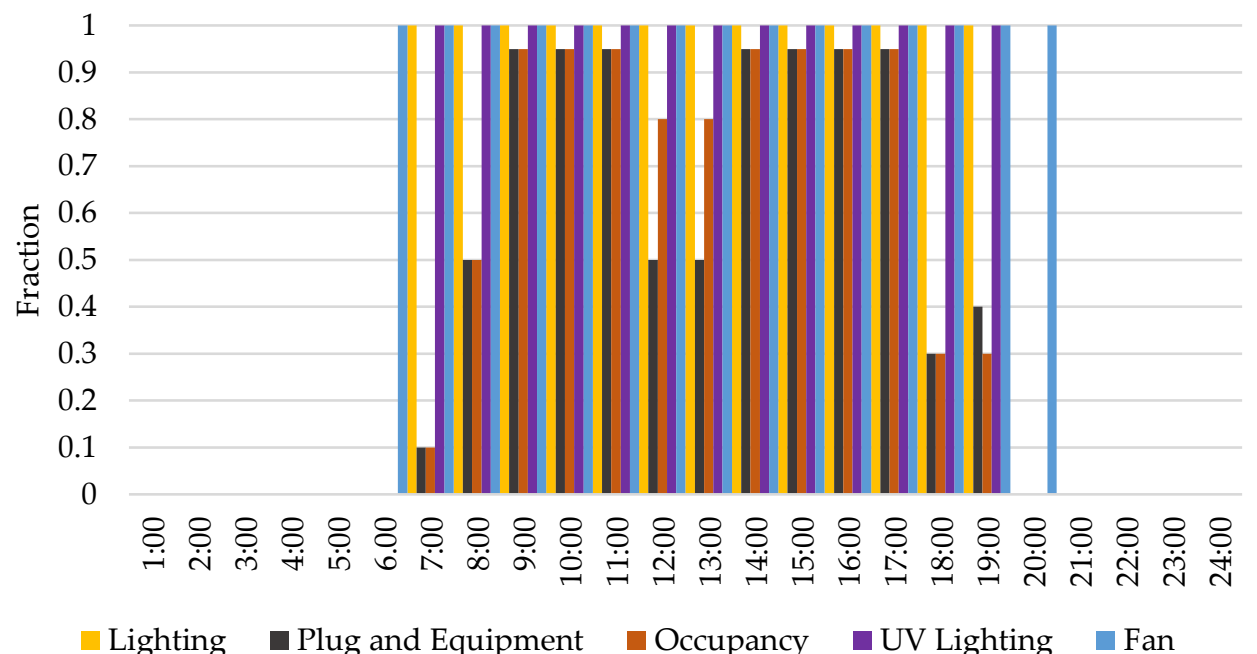

Scheme A2. Building model schedules all year on weekdays in post-C19 scenarios. Designed by the research team. 
Table A1. Fans EUI per location in pre- and post-C19 scenarios.

\begin{tabular}{|c|c|c|c|c|c|}
\hline \multirow{2}{*}{ CZ, City, Province } & \multicolumn{3}{|c|}{ Fans } & \multicolumn{2}{|c|}{ Variation Difference (\%) } \\
\hline & Pre-C19 & Post-C19 78\% & Post-C19 84\% & Post-C19 78\% & Post-C19 84\% \\
\hline 1-A, Haikou, Hainan & 16.71 & 14.94 & 15.20 & $-10.59 \%$ & $-9.04 \%$ \\
\hline 2-A, Guangzhou, Guangdong & 15.73 & 14.59 & 14.75 & $-7.25 \%$ & $-6.23 \%$ \\
\hline 3-A, Shanghai, Shanghai & 15.07 & 16.99 & 16.97 & $+12.74 \%$ & $+12.61 \%$ \\
\hline 3-C, Kunming, Yunnan & 11.87 & 13.12 & 13.09 & $+10.53 \%$ & $+10.28 \%$ \\
\hline 4-A, Xi'an, Shaanxi & 19.82 & 23.03 & 22.95 & $+16.20 \%$ & $+15.79 \%$ \\
\hline 4-B, Beijing, Beijing & 24.45 & 29.47 & 29.34 & $+20.53 \%$ & $+20.00 \%$ \\
\hline 4-H, Chamdo, Xizang & 22.84 & 28.73 & 28.49 & $+25.79 \%$ & $+24.74 \%$ \\
\hline 5-A, Shenyang, Liaoning & 31.43 & 44.24 & 44.07 & $+40.76 \%$ & $+40.22 \%$ \\
\hline 5-B, Lanzhou, Gansu & 23.56 & 30.80 & 30.63 & $+30.73 \%$ & $+30.01 \%$ \\
\hline 5-H, Lhasa, Xizang & 21.94 & 26.79 & 26.62 & $+22.11 \%$ & $+21.33 \%$ \\
\hline 6-A, Changchun, Jilin & 42.04 & 59.52 & 59.29 & $+41.58 \%$ & $+41.03 \%$ \\
\hline 6-B, Ordos, Nei Menggu & 31.48 & 41.41 & 41.18 & $+31.54 \%$ & $+30.81 \%$ \\
\hline 6-H, Xi'ning, Qinghai & 32.11 & 40.49 & 40.25 & $+26.10 \%$ & $+25.35 \%$ \\
\hline 7, Harbin, Heilongjiang & 45.57 & 64.97 & 64.73 & $+42.57 \%$ & $+42.05 \%$ \\
\hline 7-H, Delinghá, Qinghai & 37.19 & 47.09 & 46.86 & $+26.62 \%$ & $+26.00 \%$ \\
\hline 8, Tahé, Heilongjiang & 60.72 & 94.84 & 94.60 & $+56.19 \%$ & $+55.80 \%$ \\
\hline 8-H, Yushu, Qinghai & 35.82 & 44.64 & 44.38 & $+24.62 \%$ & $+23.90 \%$ \\
\hline
\end{tabular}

Table A2. Lighting EUI per location in pre- and post-C19 scenarios.

\begin{tabular}{cccccc}
\hline \multirow{2}{*}{ CZ, City, Province } & \multicolumn{3}{c}{ Lighting } & \multicolumn{2}{c}{ Variation Difference (\%) } \\
\cline { 2 - 6 } & Pre-C19 & Post-C19 78\% & Post-C19 84\% & Post-C19 78\% & Post-C19 84\% \\
\hline 1-A, Haikou, Hainan & 18.60 & 9.56 & 9.56 & $-48.60 \%$ & $-48.60 \%$ \\
2-A, Guangzhou, Guangdong & 18.90 & 10.07 & 10.07 & $-46.72 \%$ & $-46.72 \%$ \\
3-A, Shanghai, Shanghai & 18.94 & 10.31 & 10.31 & $-45.56 \%$ & $-45.56 \%$ \\
3-C, Kunming, Yunnan & 18.53 & 9.57 & 9.57 & $-48.35 \%$ & $-48.35 \%$ \\
4-A, Xi'an, Shaanxi & 18.62 & 9.61 & 9.61 & $-48.39 \%$ & $-48.39 \%$ \\
4-B, Beijing, Beijing & 18.90 & 10.23 & 10.23 & $-45.87 \%$ & $-45.87 \%$ \\
4-H, Chamdo, Xizang & 18.41 & 9.61 & 9.61 & $-47.80 \%$ & $-47.80 \%$ \\
5-A, Shenyang, Liaoning & 19.34 & 10.58 & 10.58 & $-45.29 \%$ & $-45.29 \%$ \\
5-B, Lanzhou, Gansu & 18.78 & 9.85 & 9.85 & $-47.55 \%$ & $-47.55 \%$ \\
5-H, Lhasa, Xizang & 18.03 & 9.40 & 9.40 & $-47.86 \%$ & $-47.86 \%$ \\
6-A, Changchun, Jilin & 18.83 & 9.93 & 9.93 & $-47.27 \%$ & $-47.27 \%$ \\
6-B, Ordos, Nei Menggu & 18.53 & 9.60 & 9.60 & $-48.19 \%$ & $-48.19 \%$ \\
6-H, Xi'ning, Qinghai & 18.20 & 7.90 & 7.90 & $-56.59 \%$ & $-56.59 \%$ \\
7, Harbin, Heilongjiang & 18.92 & 10.46 & 10.46 & $-44.71 \%$ & $-44.71 \%$ \\
7-H, Delinghá, Qinghai & 18.69 & 9.67 & 9.67 & $-48.26 \%$ & $-48.26 \%$ \\
8, Tahé, Heilongjiang & 18.81 & 10.44 & 10.44 & $-44.50 \%$ & $-44.50 \%$ \\
8-H, Yushu, Qinghai & 18.13 & 9.44 & 9.44 & $-47.93 \%$ & $-47.93 \%$ \\
\hline
\end{tabular}

\section{Appendix B}

Appendix B.1. Cove.tool's Assessments

Reports Pre- and Post-C19 Scenarios

This document contains the reports generated by Cove.tool software concerning the BEM energy analysis on pre- and post-C19 scenarios. 
Baseline Energy $\odot$

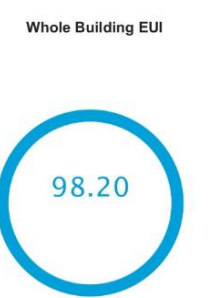

Office

$$
98.2 \mathrm{kWh} / \mathrm{m}^{2} / \mathrm{yr}
$$

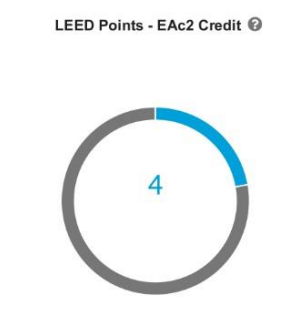

Electricity

\#59708.01/yr 2030

$¥ 32377.59 /$ yr $\quad$ Baseline

$$
\text { Emissions }
$$

You Save

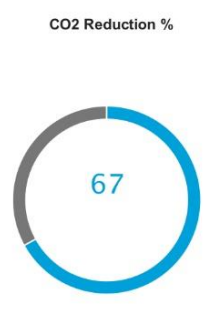

2372.3

Tonne/CO2e/yr

Tonne/CO2e/yr

(อ)

Figure A1. Zone 1-A Haikou, Hainan (pre-COVID-19 scenario).

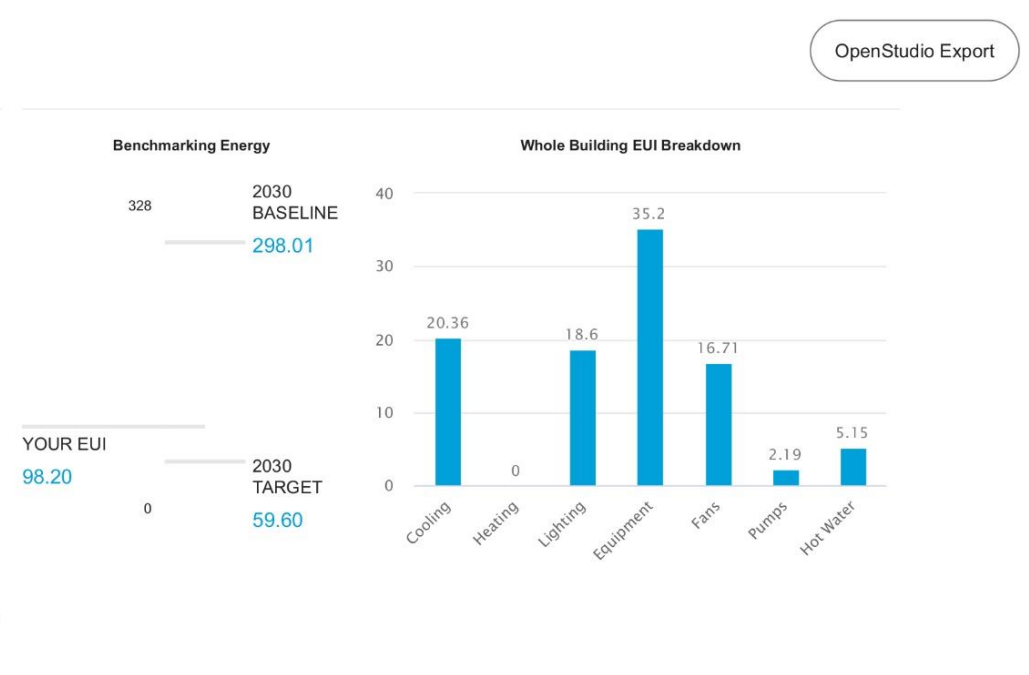

\section{Baseline Energye}

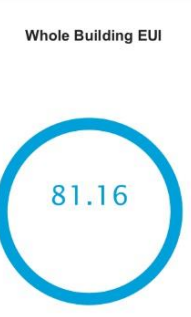

Office
LEED Points - EAc2 Credit @

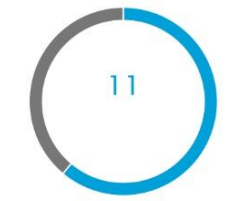

Electricity $¥ 1274042.31 / \mathrm{yr} \quad 2030$ Natural Gas $¥ 32374.1 / \mathrm{yr}$ CO2 Reduction \%

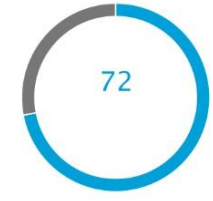

2361.7 Tonne/CO2e/yr 643.2 Tonne/CO2e/yr 258 Trucks of lee/yr

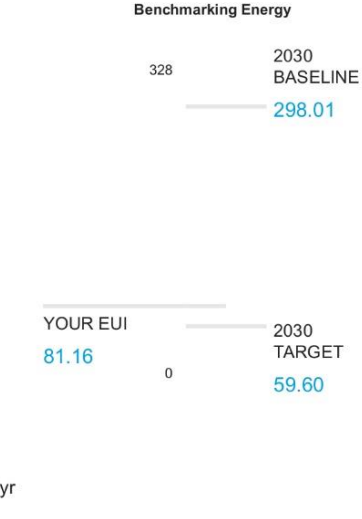

Openstudio Export

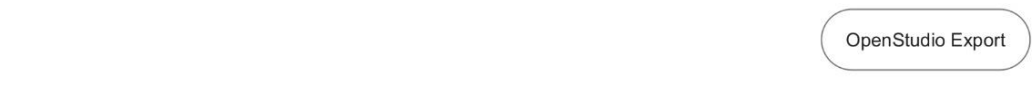

nario). 
Baseline Energy $\odot$

LEED Points - EAc2 Credit @

CO2 Reduction \%

Benchmarking Energy

le Building EUI Breakdown

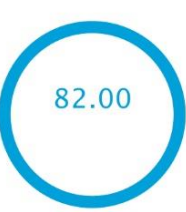

Office

$82 \mathrm{kWh} / \mathrm{m}^{2} / \mathrm{yr}$

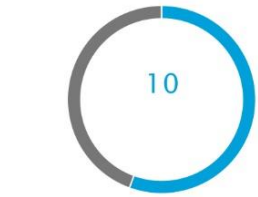

Electricity
Natural Gas

$¥ 1288199.19$ Mr 2030 Natural Gas $¥ 32373.94 \mathrm{yr}$

Baseline

2362.3

Emissions 650 Tonne/Cozelyr

257 Trucks of

Figure A3. Zone 1-A Haikou, Hainan (post-COVID-19 84\% scenario)

Baseline Energye

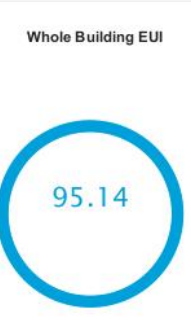

Office
$95.14 \mathrm{kWh} / \mathrm{m}^{2} / \mathrm{yr}$

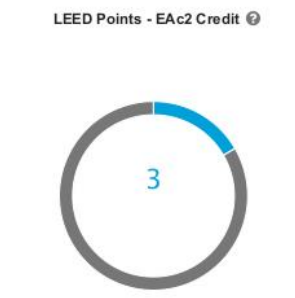

Electricity $¥ 1488044.33 / y r \quad 2030$ Natural Gas $¥ 39982.62 / \mathrm{yr} \quad$ Baseline Emissions

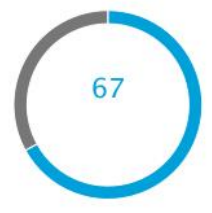

2292.8

Tonne/CO2e/yr

Tonne/CO2e/yr

(2)

OpenStudio Export
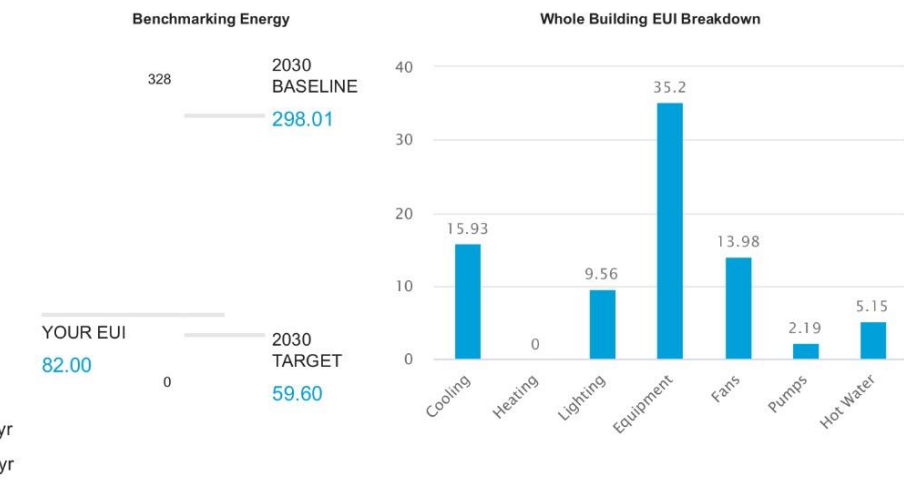
Baseline Energy $\odot$

Whole Building EUI

LEED Points - EAC2 Credit \&

C02 Reduction \%

Benchmarking Energy

ole Building EUI Breakdown

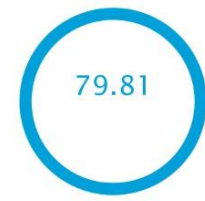

Office

$79.81 \mathrm{kWh} / \mathrm{m}^{2} / \mathrm{yr}$

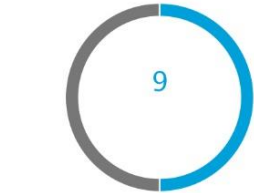

Electricity

$¥ 1230117.61 / y r \quad 2030$

$¥ 40352.23 / \mathrm{yr}$

Baseline

Emissions 628.1

248 Trucks of Ice/y

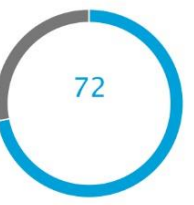

280

Tonne/CO2e/yr

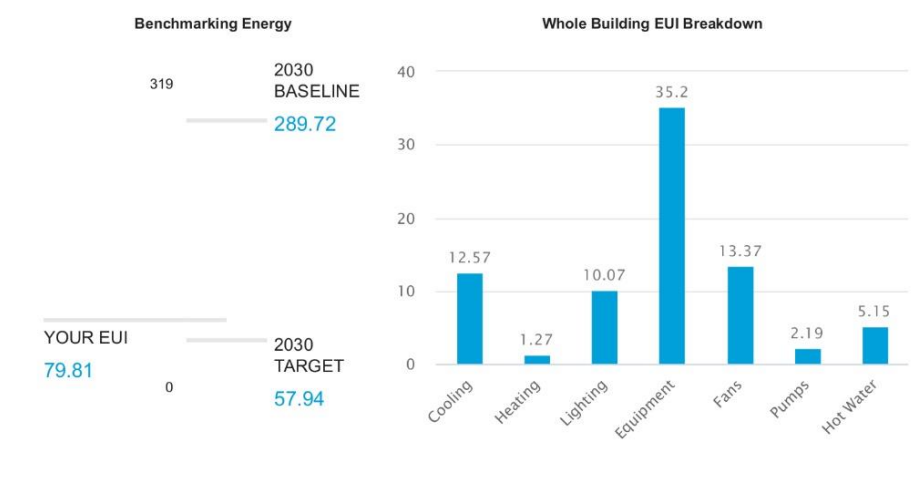

Figure A5. Zone 2-A Guangzhou, Guangdong (post-COVID-19 78\% scenario)

\section{Baseline Energye}

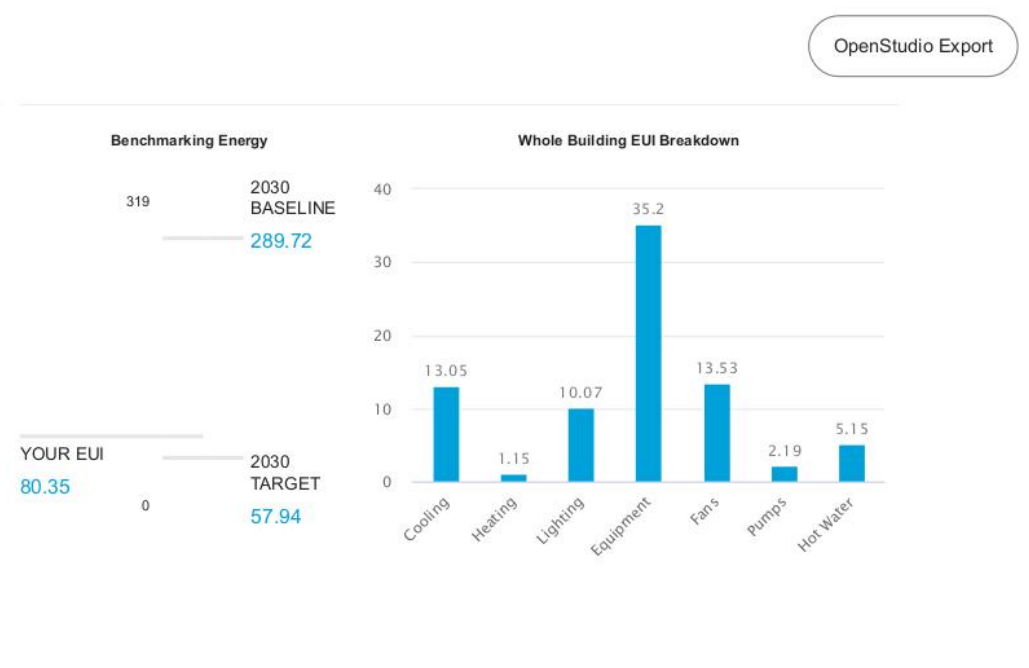

Figure A6. Zone 2-A Guangzhou, Guangdong (post-COVID-19 84\% scenario). 
Baseline Energy $\odot$

OpenStudio Export

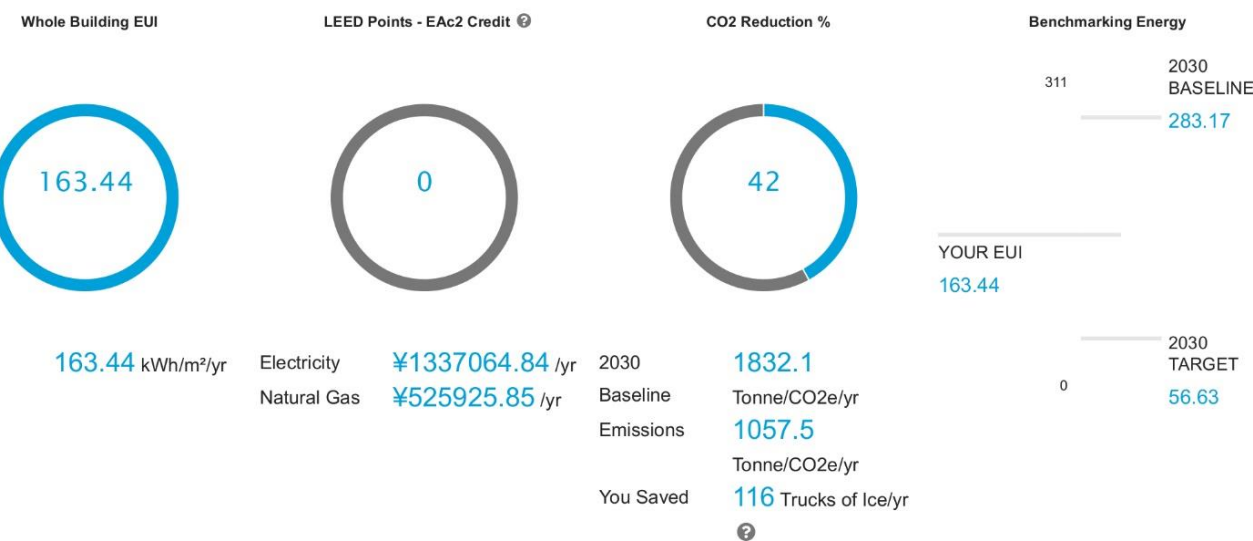

Figure A7. Zone 3-A Shanghai, Shanghai (pre-COVID-19 scenario).

Baseline Energy ${ }^{\circ}$
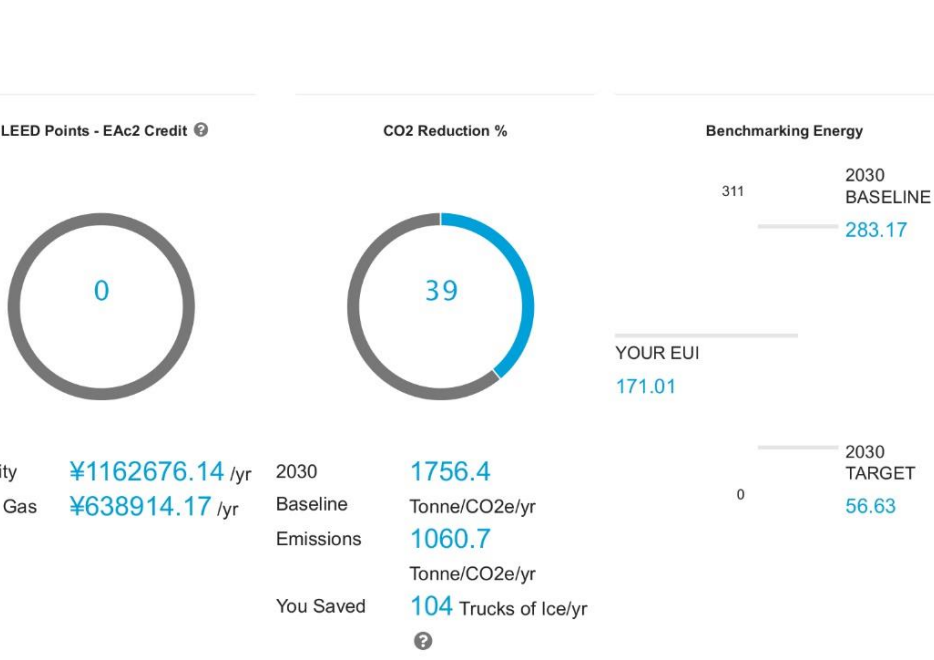

$\begin{array}{lll}\text { Electricity } & ¥ 1162676.14 / y r & 2030 \\ \text { Natural Gas } & ¥ 638914.17 / y r & \text { Baseline }\end{array}$

You Saved 104 Trucks of lceir

Figure A8. Zone 3-A Shanghai, Shanghai (post-COVID-19 78\% scenario). 
Baseline Energy ${ }^{\circledR}$

LEED Points - EAC2 Credit 8

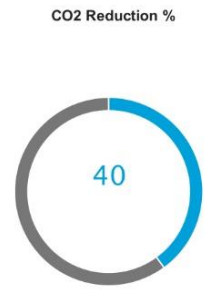

OpenStudio Export

Whole Building E

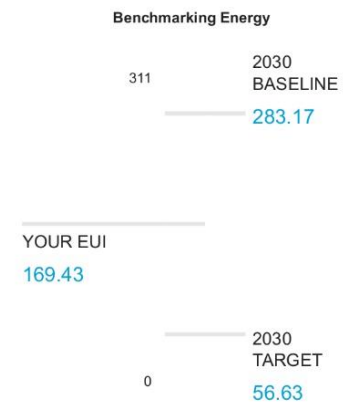

Whole Building EUI Breakdown
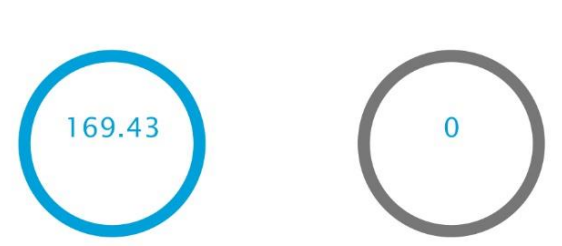

$169.43 \mathrm{kWh} / \mathrm{m}^{2} / \mathrm{s}$

\section{Electricity}

Baseline
Emissions

Tonne/CO2e/s

You Saved 106 Trucks of Ice/yr

Figure A9. Zone 3-A Shanghai, Shanghai (post-COVID-19 84\% scenario).

Baseline Energy $\odot$

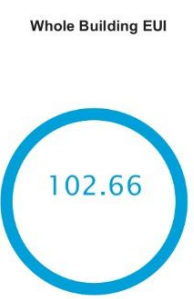

Office

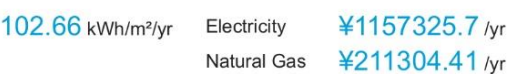
Natural Gas $¥ 211304.41$ yr

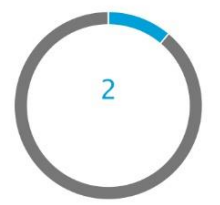

Baseline

Emissions

161 Trucks of Ice/yr
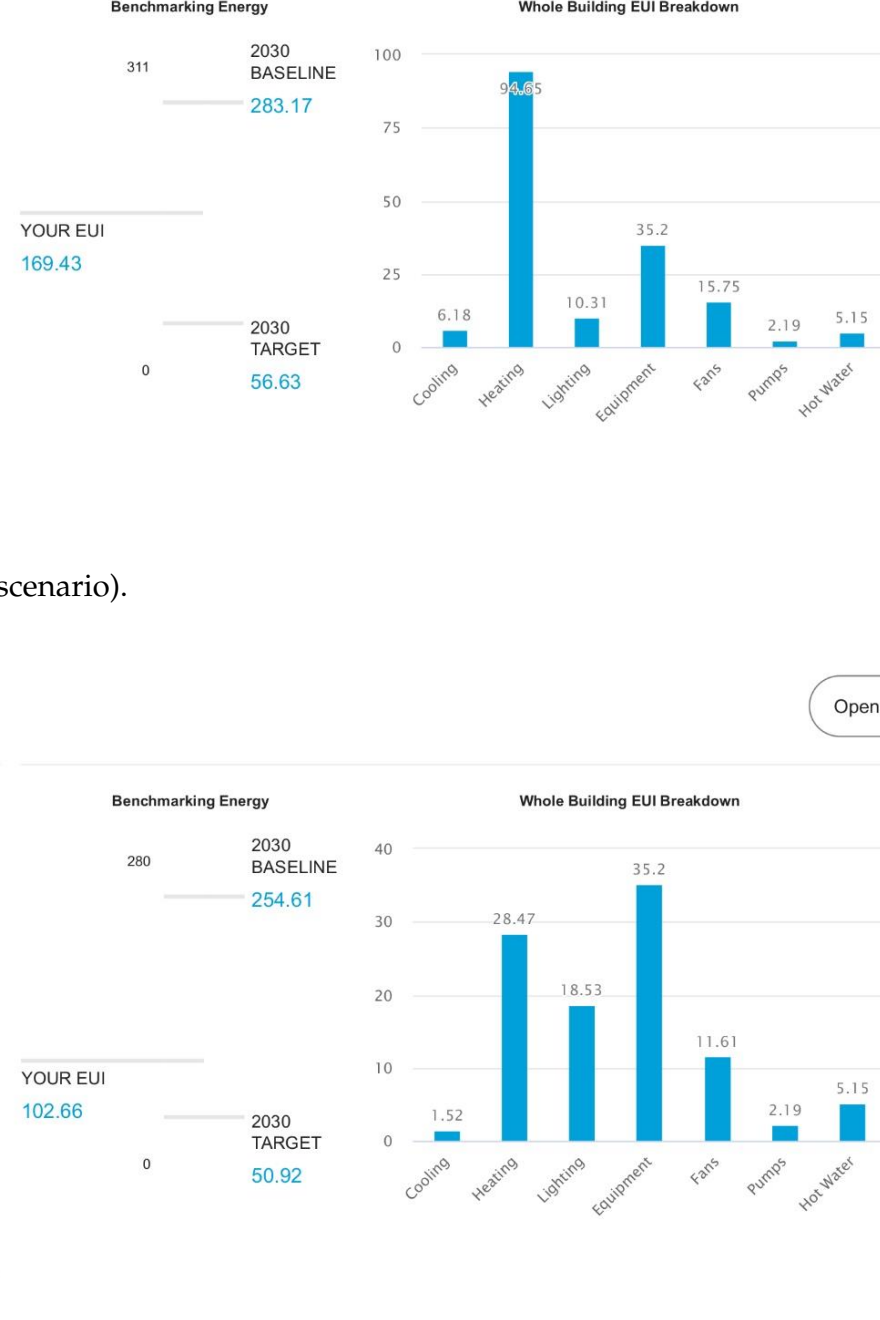

Figure A10. Zone 3-C Kunming, Yunnan (pre-COVID-19 scenario). 
Baseline Energy $\odot$

CO2 Reduction \%

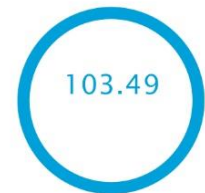

Office
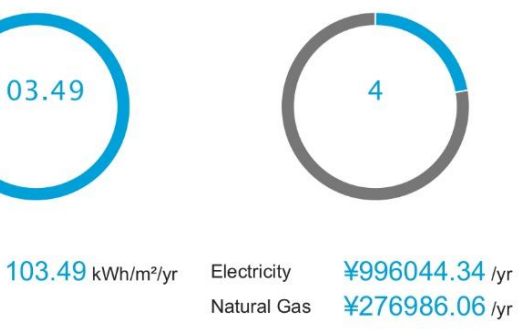

Natural Gas $\quad ¥ 276986.06$

Emissions Tonne/CO2e/y

You Saved 153 Trucks of lceir

Figure A11. Zone 3-C Kunming, Yunnan (post-COVID-19 78\% scenario).

Baseline Energy e

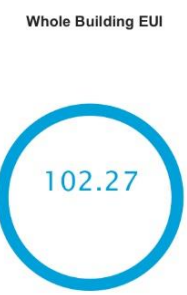

Office
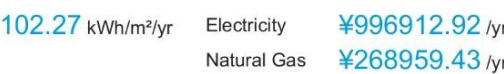

$$
\text { Natural Gas } ¥ 268959.43 / y
$$

Baseline

$$
\text { Tonne/CO2e/yr }
$$

(อ)

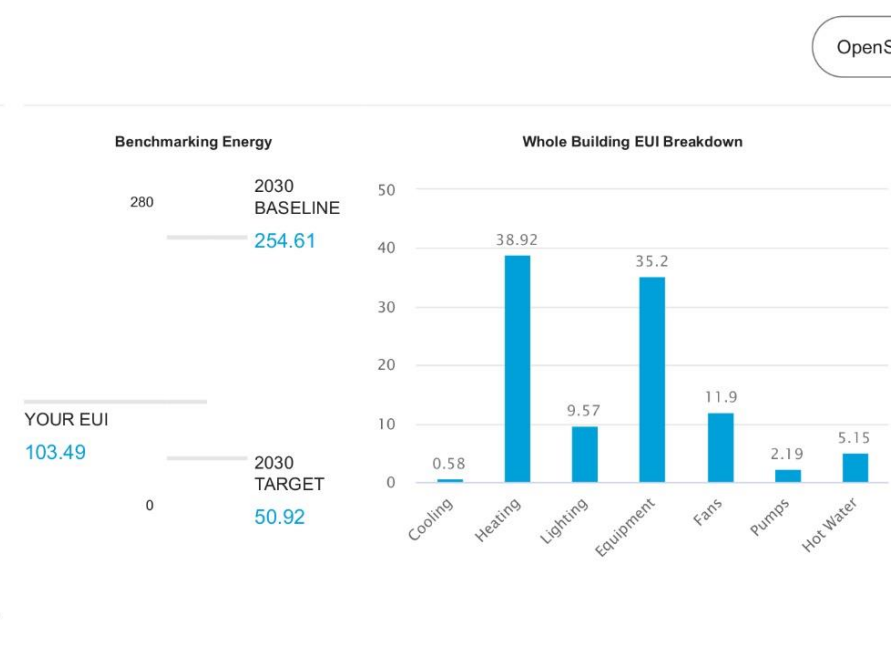

OpenStudio Export

Tonne/cose/4r

0

\section{9}

2 Reduction \%

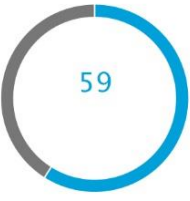

YOUR EUI

102.2

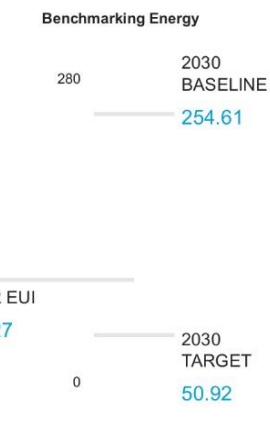

50.92

OpenStudio Export

Figure A12. Zone 3-C Kunming, Yunnan (post-COVID-19 84\% scenario). 
Baseline Energy ${ }^{8}$

LEED Points - EAC2 Credit @
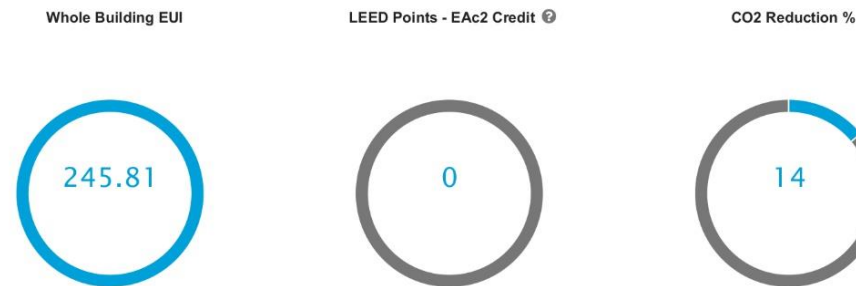

Office

$245.81 \mathrm{kWh} / \mathrm{m}^{2} / \mathrm{r}$ $\begin{array}{lll}\text { Electricity } & ¥ 1410386.98 / y r & 2030 \\ \text { Natural Gas } & ¥ 1016181.23 / y r & \text { Basel }\end{array}$ Emissions You Saved

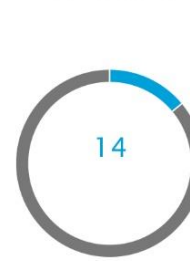

1720.5 Tonne/CO2e/yr 1474.2

$$
37 \text { Trucks of lce }
$$$$
37 \text { Trucks of lce/yr }
$$$$
\text { อ }
$$

Figure A13. Zone 4-A Xi'an, Shaanxi (pre-COVID-19 scenario).

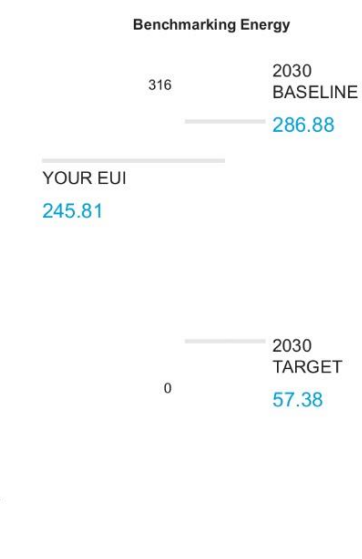

OpenStudio Export

200

200
Baseline Energy $\odot$

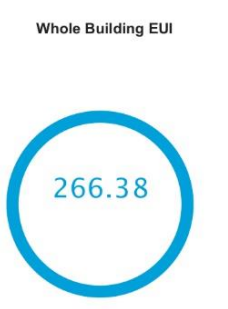

Office

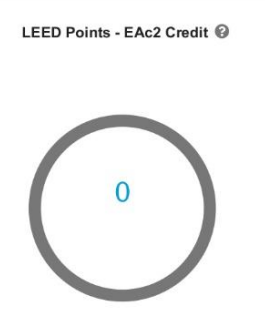

Electricity
Natural Gas

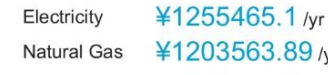

Emissions

(อ)

Tonne/Co2e/yr

Tonne/CO2e/sr

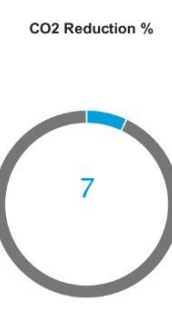

663.6

8 Trucks of Ice/y

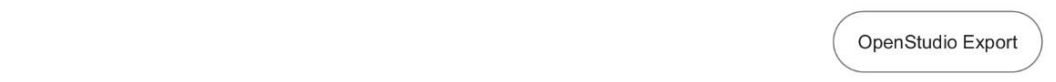

Figure A14. Zone 4-A Xi'an, Shaanxi (post-COVID-19 78\% scenario). 
Baseline Energy $\odot$

Whole Building Eu

LEED Points - EAC2 Credit @

$\cos$ Reduction \%

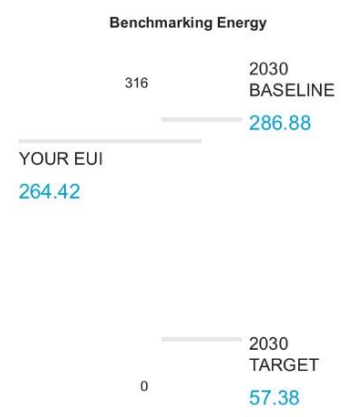

Whole Building EUI Breakdown

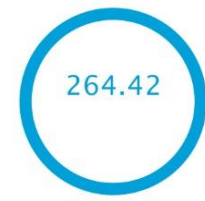

Office

$264.42 \mathrm{kWh} / \mathrm{m}^{2} / \mathrm{yr}$

$¥ 1190084.15 / y r \quad$ Baseline

Emissions $\quad 1535.8$

$\begin{array}{ll}\text { You Saved } & 20 \text { Trucks of Ice//yr }\end{array}$

(2)

Figure A15. Zone 4-A Xi'an, Shaanxi (post-COVID-19 84\% scenario).

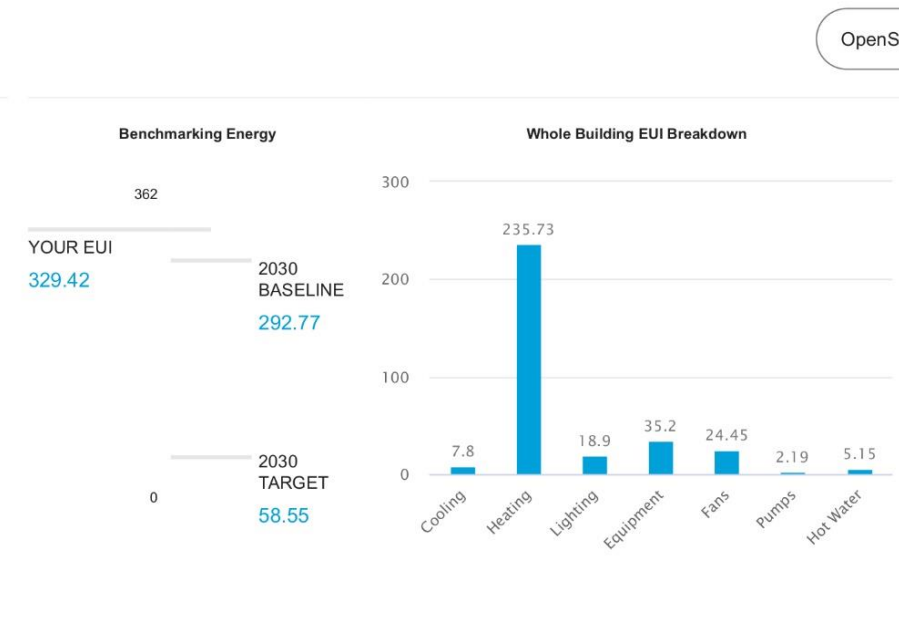

Figure A16. Zone 4-B Beijing, Beijing (pre-COVID-19 scenario) 
Baseline Energy $\odot$

LEED Points - EAc2 Credit @
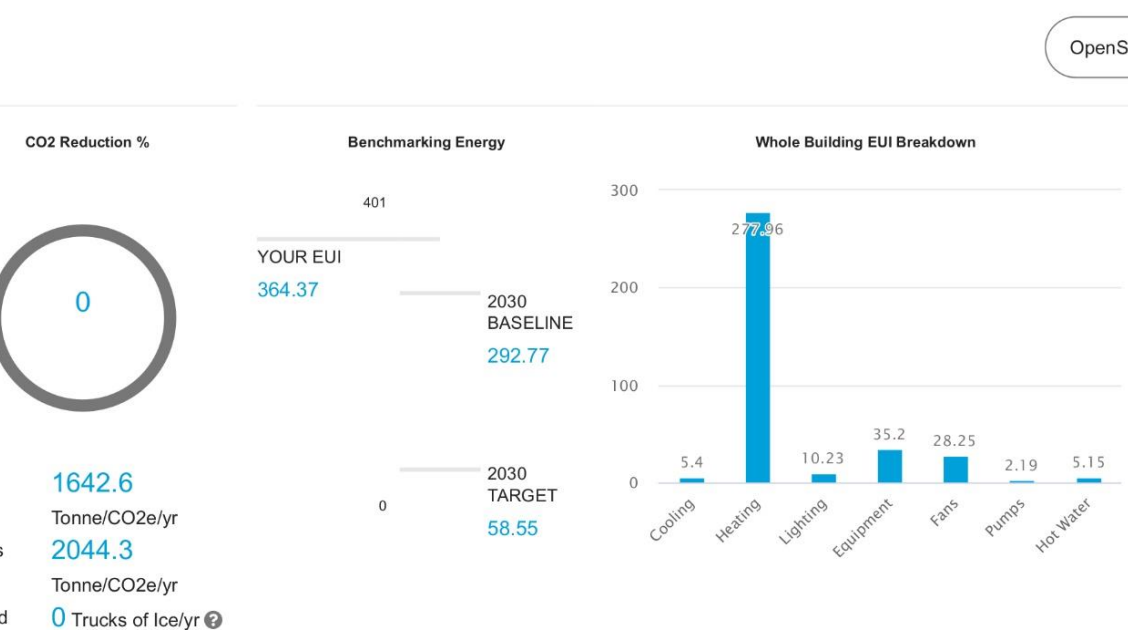

Office

$$
\begin{array}{lllll}
364.37 \mathrm{kWh} / \mathrm{m}^{2} / \mathrm{yr} & \text { Electricity } & ¥ 1362103.64 / \mathrm{yr} & \text { 2030 } & 1642.6 \\
& \text { Natural Gas } & ¥ 1779511.95 / \mathrm{yr} & \text { Baseline } & \text { Tonne/CO2e/yr } \\
& & & \text { Emissions } & 2044.3 \\
& & & \text { Tonne/CO2e/yr } \\
& & & &
\end{array}
$$

Figure A17. Zone 4-B Beijing, Beijing (post-COVID-19 78\% scenario)

Baseline Energy $\odot$

$$
\text { Openstudio Export }
$$

LEED Points - EAc2 Credit $\odot$

CO2 Reduction \%

Benchmarking Energy
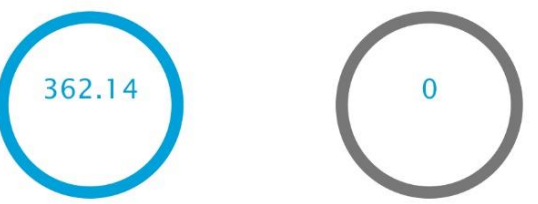

Electricity Natural Gas $¥ 1764585.9 / \mathrm{yr} \quad$ Baseline

Emissions 2033.8

You Saved Tonne/CO2e/yr

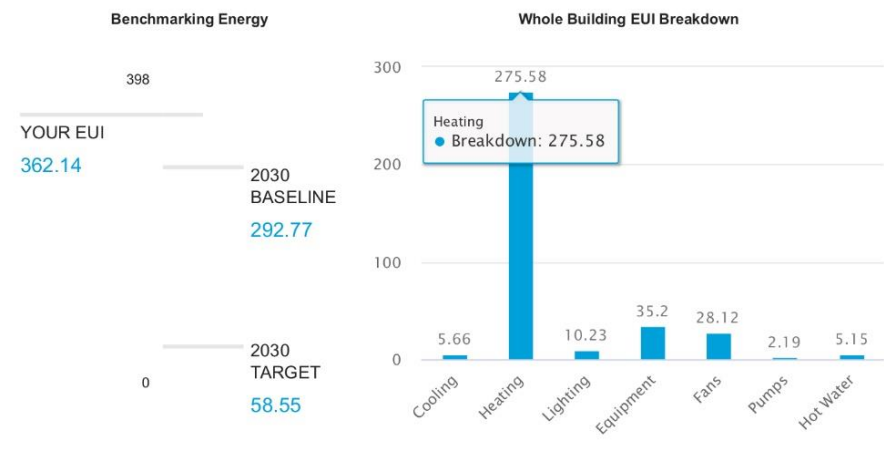

Figure A18. Zone 4-B Beijing, Beijing (post-COVID-19 84\% scenario) 
Baseline Energy ${ }^{\odot}$

LEED Points - EAc2 Credit @

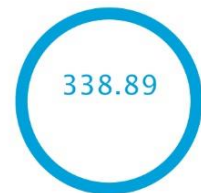

Office

$$
\begin{array}{lllll}
338.89 \mathrm{kWh} / \mathrm{m}^{2} / \mathrm{yr} & \text { Electricity } & ¥ 1331965.74 / \mathrm{yr} & 2030 & 1636.2 \\
& \text { Natural Gas } & ¥ 1630612.68 / \mathrm{yr} & \text { Baseline } & \text { Tonne/CO2e//yr } \\
& & \text { Emissions } & 1913.9 \\
& & & \text { Tonne/CO2e/yr } \\
& & \text { You Saved } & 0 \text { Trucks of lce//yr B }
\end{array}
$$

$\cos$ Reduction \%

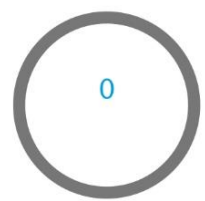

Figure A19. Zone 4-H Chamdo, Xizang (pre-COVID-19 scenario).

Baseline Energy ${ }^{\circ}$

Whole Building EUI

LEED Points - EAc2 Credit (8)

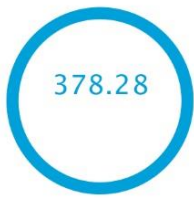

Office

$$
\begin{array}{lllll}
378.28 \mathrm{kWh} / \mathrm{m}^{2} / \mathrm{yr} & \text { Electricity } & ¥ 1262156.32 / \mathrm{yr} & 2030 & 1602.9 \\
& \text { Natural Gas } & ¥ 1904410.47 / \mathrm{yr} & \text { Baseline } & \text { Tonne/CO2e/yr } \\
& & & \text { Emissions } & 2092.9 \\
& & & \text { Toun Saved } & 0 \text { Truckse of Ice/yr }
\end{array}
$$

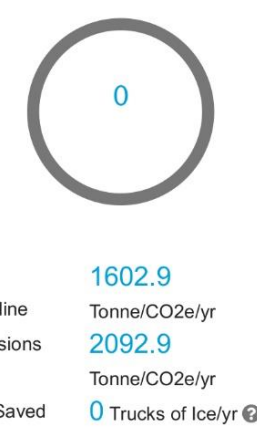

OpenStudio Export Whole Building EUI Broakdown

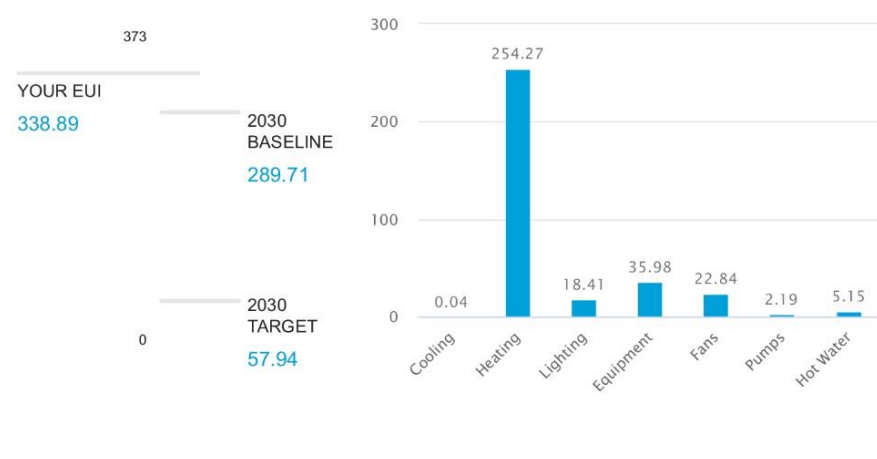

Figure A20. Zone 4-H Chamdo, Xizang (post-COVID-19 78\% scenario) 
Baseline Energy $\odot$

LEED Points - EAc2 Credit @

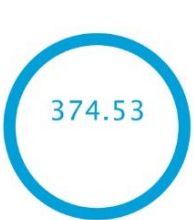

Office

$374.53 \mathrm{kWh} / \mathrm{m}^{2} / \mathrm{r}$

$\begin{array}{ll}¥ 1258233.4 / y r & 2030 \\ ¥ 1882320.77 / y r & B a s e l i n e\end{array}$

Emissions

Tonne/CO2e/yr

You Saved 0 Trucks of Icelyr

Figure A21. Zone 4-H Chamdo, Xizang (post-COVID-19 84\% scenario).

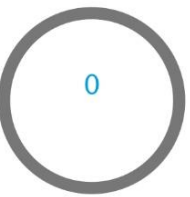

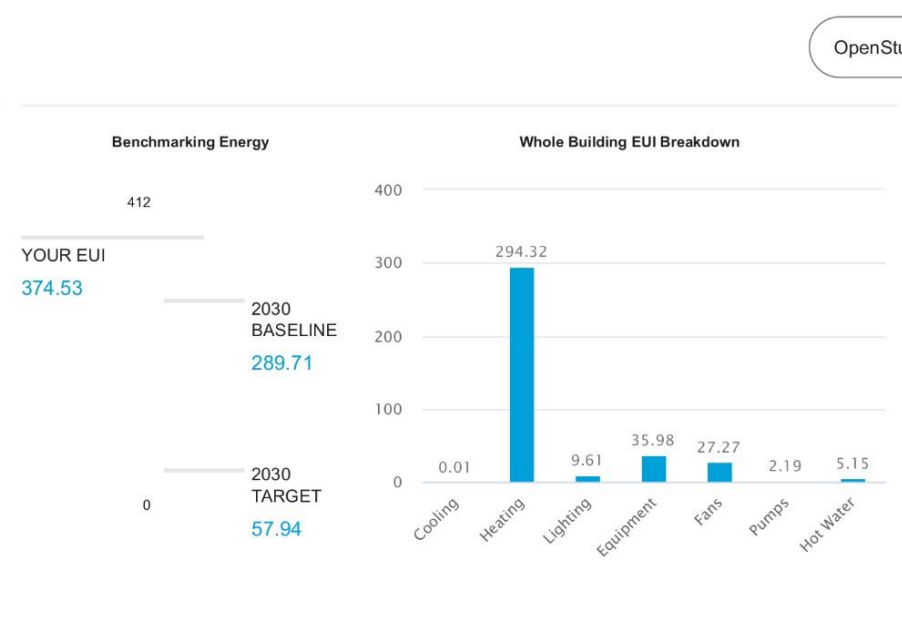

OpenStudio Export

2 Reduction \%

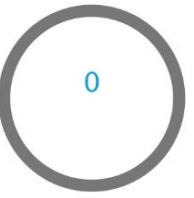

Electricity

$¥ 2493968.01 / y r \quad$ Baseline

1950

Tonne/CO2e/yr

2704.9

Tonne/CO2e/yr

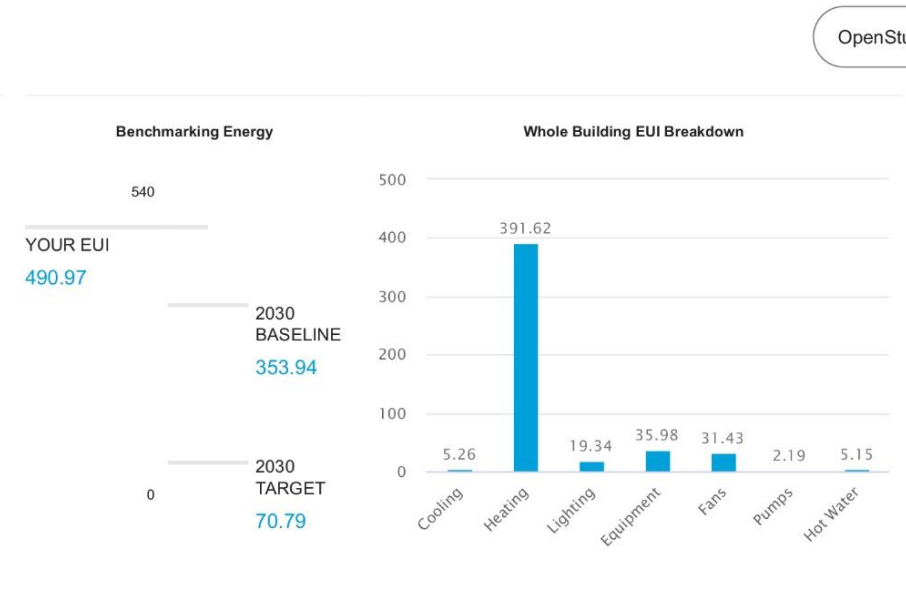

Figure A22. Zone 5-A Shenyang, Liaoning (pre-COVID-19 scenario). 
Baseline Energy $\odot$

LEED Points - EAC2 Credit @

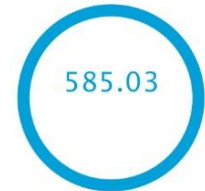

Office

$$
\begin{array}{lllll}
585.03 \mathrm{kWh} / \mathrm{m}^{2} / \mathrm{yr} & \text { Electricity } & ¥ 1594824.96 / \mathrm{yr} & \text { 2030 } & 1916.4 \\
& \text { Natural Gas } & ¥ 3079236.13 / \mathrm{yr} & \text { Baseline } & \text { Tonne/CO2e/yr } \\
& & & \text { Emissions } & 3167.7 \\
& & & \text { Tonne/CO2e/yr } \\
& & & & 0 \text { Trucks of Ice/yry }
\end{array}
$$

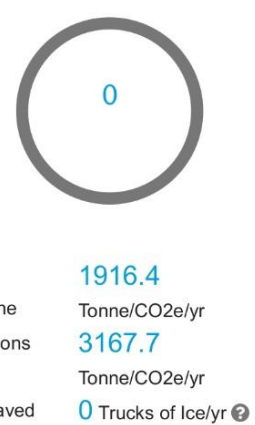

Figure A23. Zone 5-A Shenyang, Liaoning (post-COVID-19 78\% scenario).

Baseline Energy॰

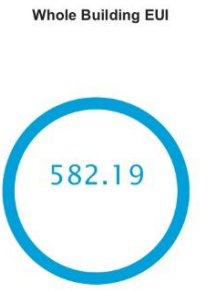

LEED Points - EAC2 Credit @

CO2 Reduction \%

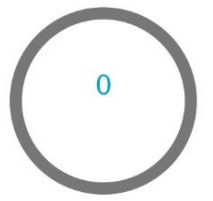

$582.19 \mathrm{kWh} / \mathrm{m}^{2} / \mathrm{s}$

Electricity $¥ 1595383.83 / y r \quad 2030$ Natural Gas $¥ 3061132.05 / y r$ Baseline

Emissions

Toun Saved

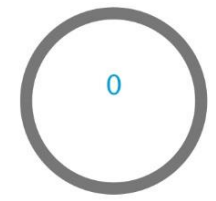

1917.4

Tonne/CO2e/yr Tonne/cor

You Saved $\quad 0$ Trucks of Ice/yr
Benchmarking Energy

644

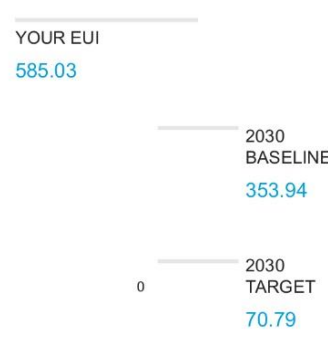

OpenStudio Export

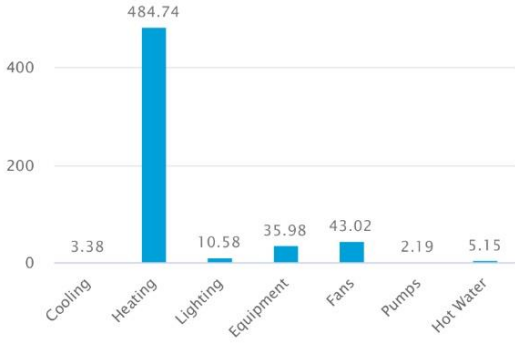


Baseline Energy $\odot$

LEED Points - EAC2 Credit @

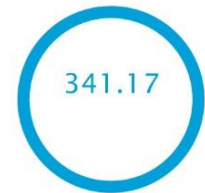

Office

$$
\begin{array}{lllll}
341.17 \mathrm{kWh} / \mathrm{m}^{2} / \mathrm{yr} & \text { Electricity } & ¥ 1401922.53 / \mathrm{yr} & 2030 & 1666 \\
& \text { Natural Gas } & ¥ 1618752.76 / \mathrm{yr} & \text { Baseline } & \text { Tonne/CO2e/yr } \\
& & & \text { Emissions } & 1938.6 \\
& & & \text { Tonne/CO2e/yr } \\
& & & \text { You Saved } & \text { 0 Trucks of lce/yr }
\end{array}
$$

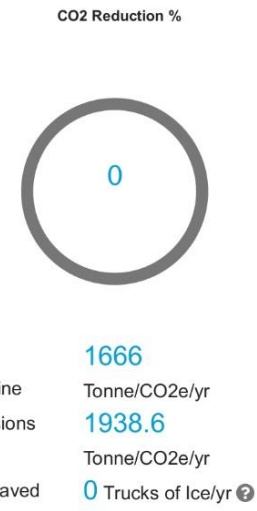

Figure A25. Zone 5-B Lanzhou, Gansu (pre-COVID-19 scenario).

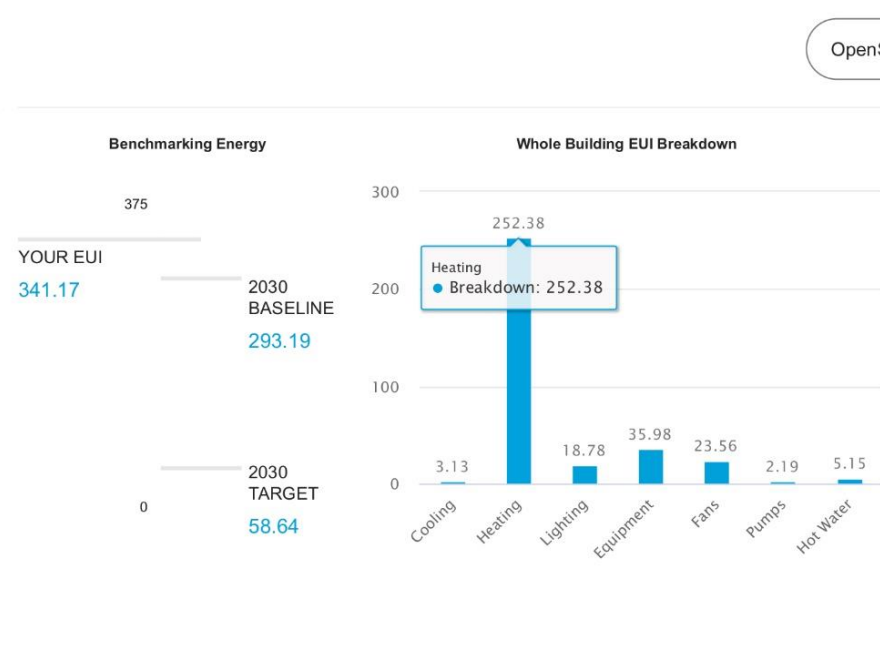

OpenStudio Export
Baseline Energy $\odot$

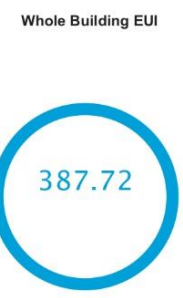

$387.72 \mathrm{kWh} / \mathrm{m}^{2} / \mathrm{s}$

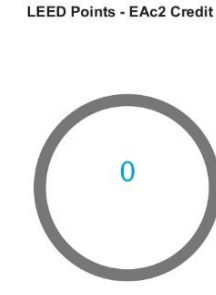

Electricity

$¥ 1940248.94 / \mathrm{yr}$ Baseline

Emissions

You Saved Tonne/CO2elyr
CO2 Reduction \%

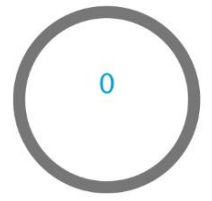

1626.

Tonne/CO2e/yr

2151.1

0 Trucks of Ice/yr @

Figure A26. Zone 5-B Lanzhou, Gansu (post-COVID-19 78\% scenario). 
Baseline Energy $\odot$

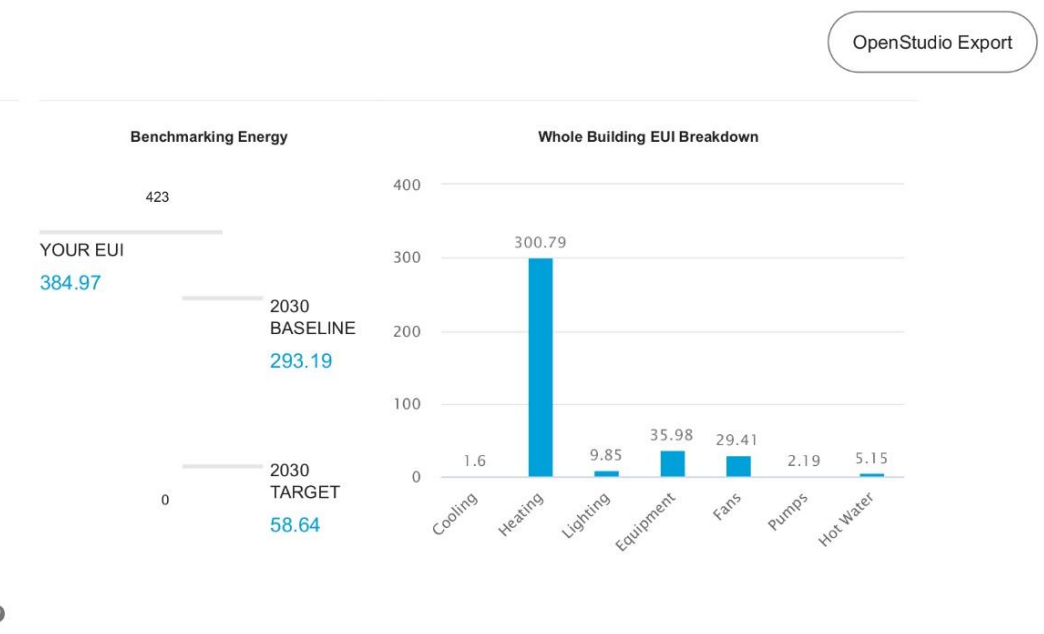

Figure A27. Zone 5-B Lanzhou, Gansu (post-COVID-19 84\% scenario).

Baseline Energy $\odot$

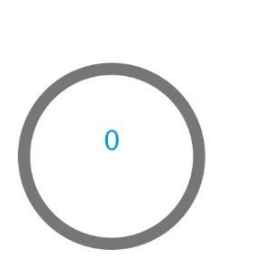

co2 Reduction \%

Electricity $¥ 1324559.99 / y r \quad 2030$

$$
\begin{array}{lll}
\text { Natural Gas } ¥ 1923048.98 / y r & \text { Baseline } & \text { Tonne/CO2e/yr } \\
& \text { Emissions } & 2137.7 \\
& \text { You Saved } & \text { Tonne/CO2e/yr } \\
& & \text { Trucks of Ice/yr }
\end{array}
$$
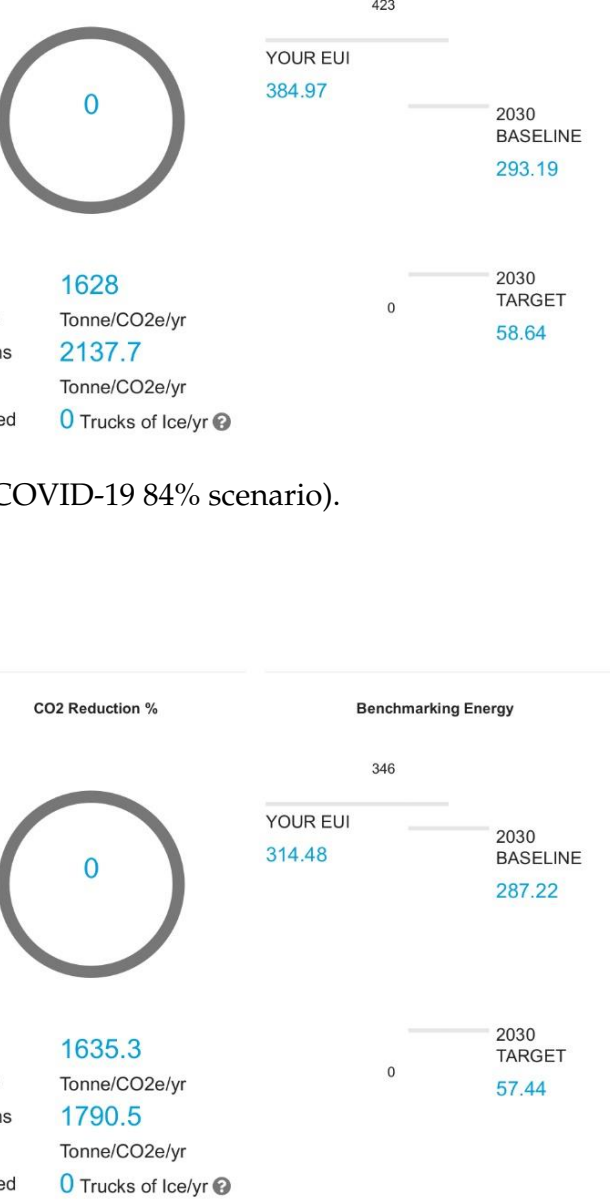

OpenStudio Export

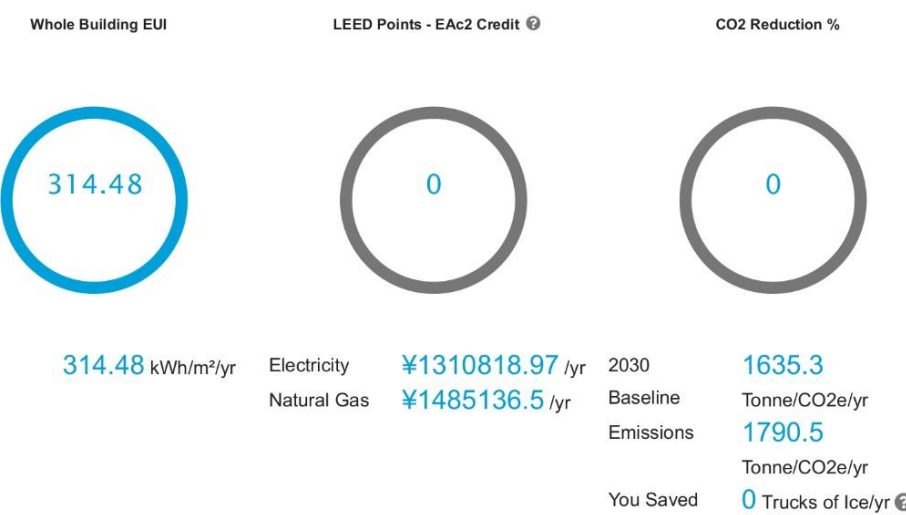

Figure A28. Zone 5-H Lhasa, Xizang (pre-COVID-19 scenario). 
Baseline Energy ${ }^{\circ}$

LEED Points - EAC2 Credit @

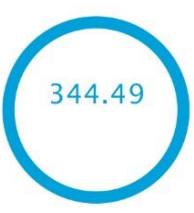

Office

$$
\begin{array}{lllll}
344.49 \mathrm{kWh} / \mathrm{m}^{2} / \mathrm{yr} & \text { Electricity } & ¥ 1226220.38 / \mathrm{yr} & \text { 2030 } & 1601.5 \\
& \text { Natural Gas } & ¥ 1705523.14 / \mathrm{yr} & \text { Baseline } & \text { Tonne/CO2e/yr } \\
& & & \text { Emissions } & 1920.8 \\
& & & \text { You Saved } & \text { T Trucke } / \text { CO2e/yr of Ice/yr }
\end{array}
$$

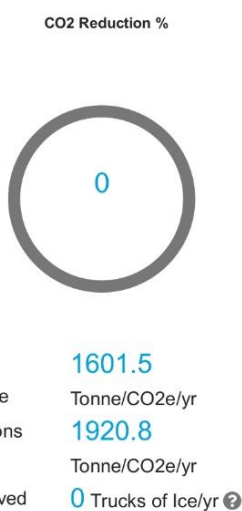

OpenStudio Export

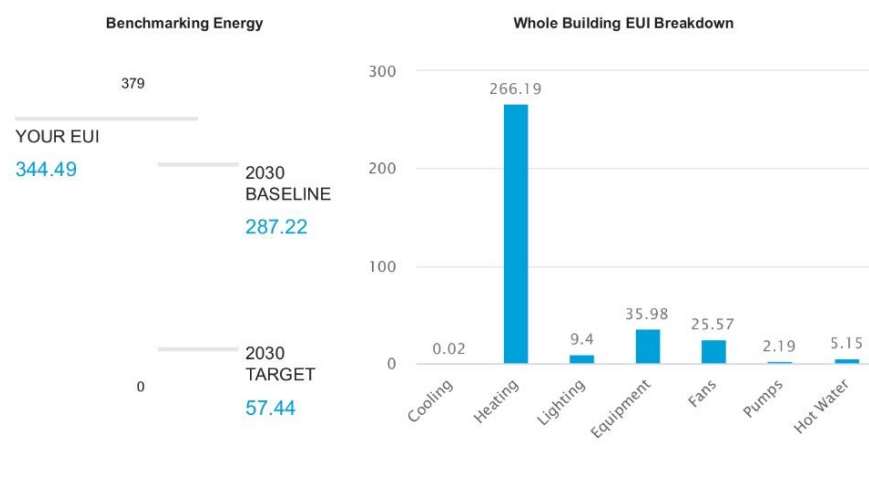

Figure A29. Zone 5-H Lhasa, Xizang (post-COVID-19 78\% scenario)

Baseline Energye

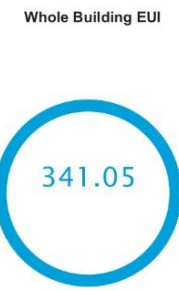

$341.05 \mathrm{kWh} / \mathrm{m}^{2} / \mathrm{yr}$

$$
\begin{array}{llll}
\text { Electricity } & ¥ 1223443.07 / y r & 2030 & 1603 \\
\text { Natural Gas } & ¥ 1684899.86 / y r & \text { Baseline } & \text { Tonne/CO2e/yr } \\
& & \text { Emissions } & 1903.5 \\
& & \text { You Saved } & \text { Tonne/CO2e/yr } \\
& & &
\end{array}
$$

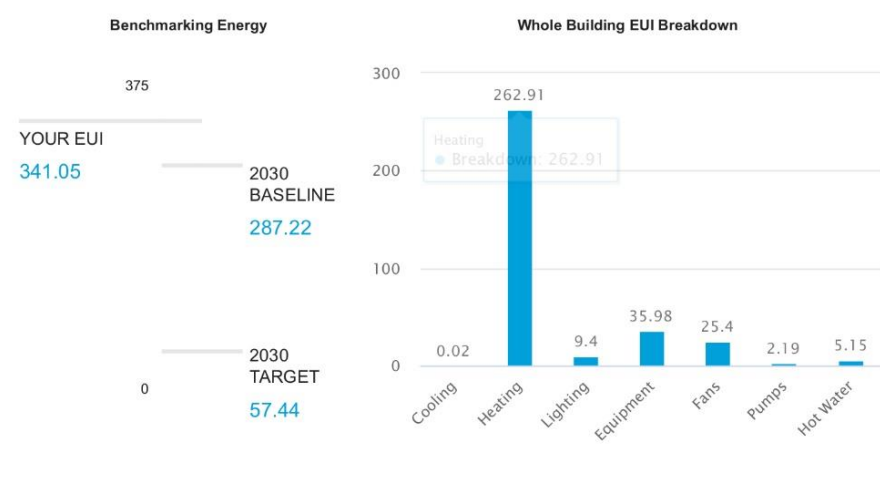

Figure A30. Zone 5-H Lhasa, Xizang (post-COVID-19 84\% scenario). 
Baseline Energy $\odot$

LEED Points - EAC2 Credit @

CO2 Reduction $\%$

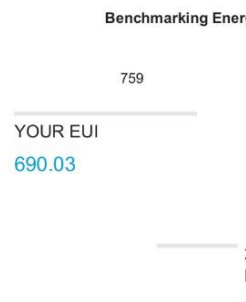

$$
\begin{array}{lllll}
690.03 \mathrm{kWh} / \mathrm{m}^{2} / \mathrm{yr} & \text { Electricity } & ¥ 1694573.7 / \mathrm{yr} & 2030 & 1944.2 \\
& \text { Natural Gas } & ¥ 3701806.65 / \mathrm{yr} & \text { Baseline } & \text { Tonne/CO2e/yr } \\
& & & \text { Emissions } & 3700.1 \\
& & & & \text { Tonne/CO2e/yr }
\end{array}
$$

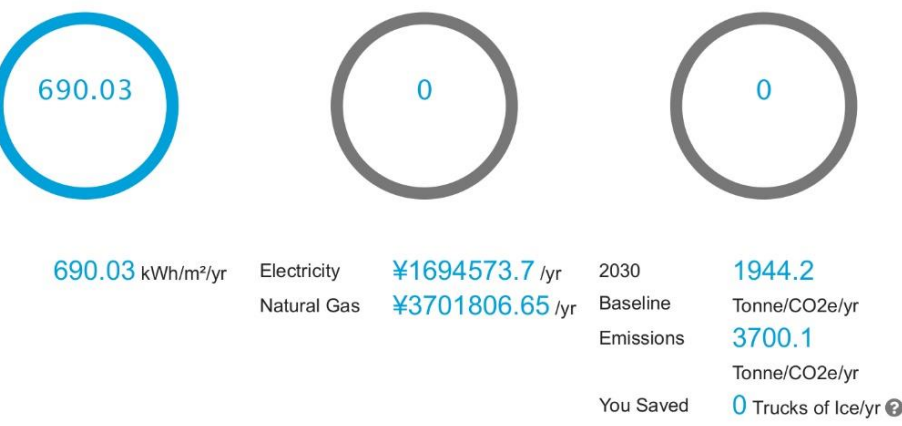

Figure A31. Zone 6-A Changchun, Jilin (pre-COVID-19 scenario).

Baseline Energy $\odot$

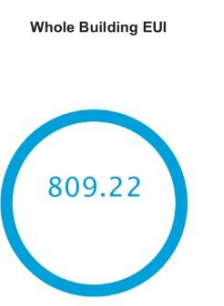

LEED Points - EAc2 Credit $\odot$

CO2 Reduction \%
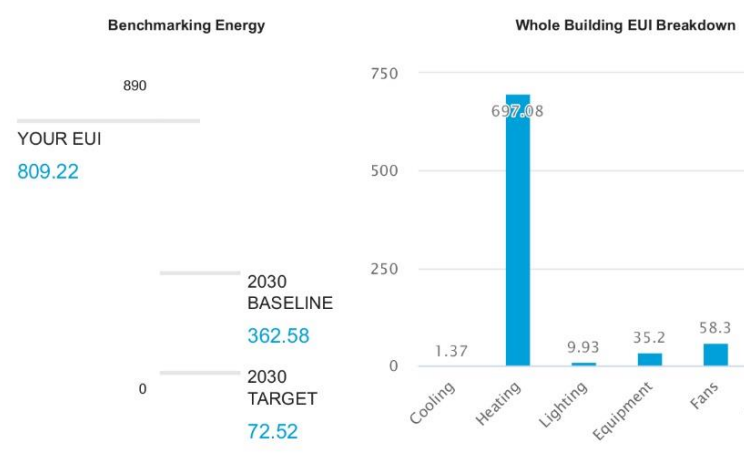

$$
\begin{array}{lllll}
809.22 \mathrm{kWh} / \mathrm{m}^{2} / \mathrm{yr} & \text { Electricity } & ¥ 1793264.92 / \mathrm{yr} & \text { 2030 } & 1927.4 \\
& \text { Natural Gas } & ¥ 4413949.38 / \mathrm{yr} & \text { Baseline } & \text { Tonne/CO2e/yr } \\
& & & \text { Emissions } & 4301.7 \\
& & \text { You Saved } & \text { Tonne/CO2e/yr } & \text { Trucks of lce/yr }
\end{array}
$$

750

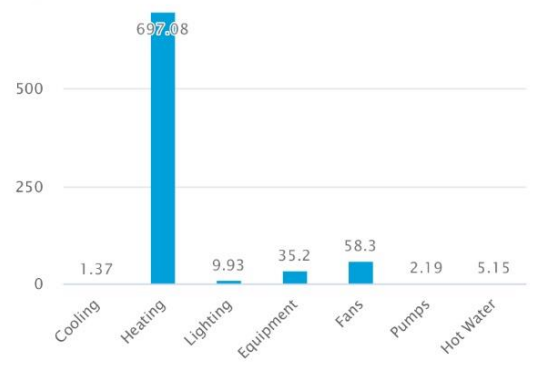

Figure A32. Zone 6-A Changchun, Jilin (post-COVID-19 78\% scenario) 
Baseline Energy $\odot$

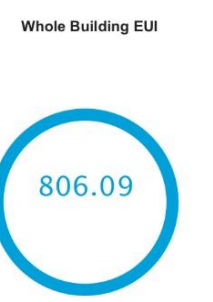

LEED Points - EAc2 Credit $\odot$
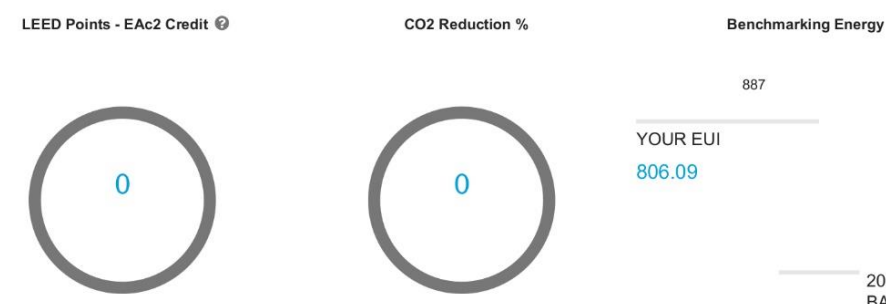

Office

$806.09 \mathrm{kWh} / \mathrm{m}^{2} / \mathrm{yr}$

$$
\begin{array}{llll}
\text { Electricity } & ¥ 1791592.1 / y r & 2030 & 1927.9 \\
\text { Natural Gas } & ¥ 4394889.19 / y r & \text { Baseline } & \text { Tonne/CO2e/yr } \\
& & \text { Emissions } & 4286.1 \\
& & \text { Tonne/CO2e/yr } \\
& & \text { You Saved } & 0 \text { Trucks of Ice/yr B }
\end{array}
$$
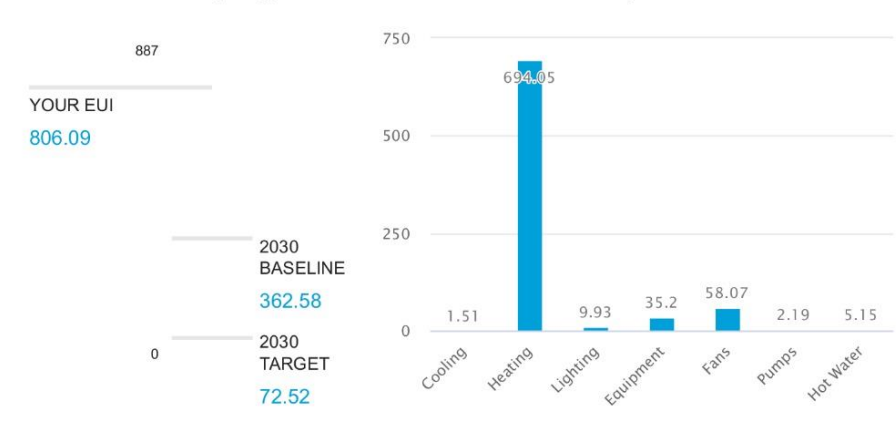

Figure A33. Zone 6-A Changchun, Jilin (post-COVID-19 84\% scenario).

Baseline Energy $\odot$

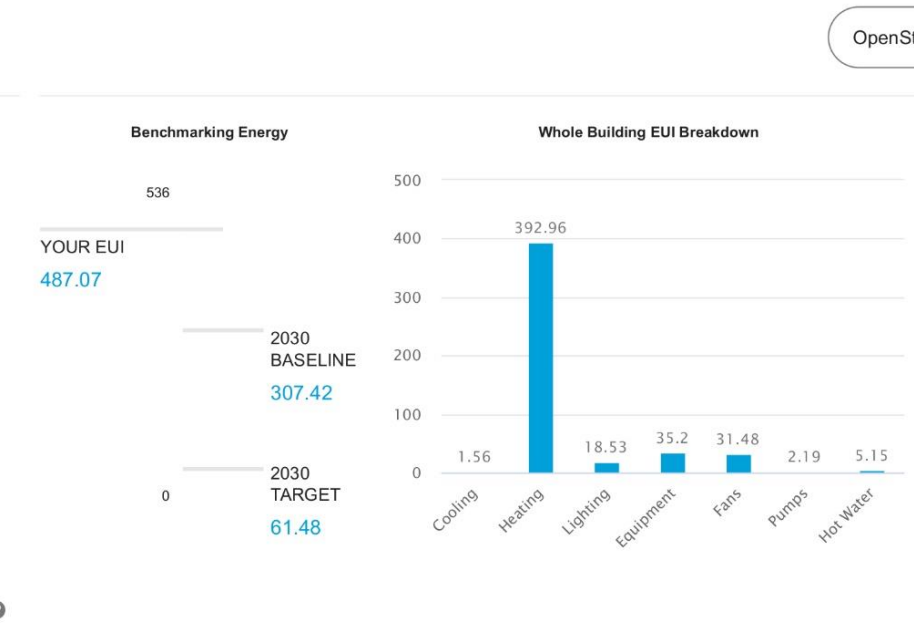

Figure A34. Zone 6-B Ordos, Nei Menggu (pre-COVID-19 scenario). 
Baseline Energy $\odot$

LEED Points - EAC2 Credit @

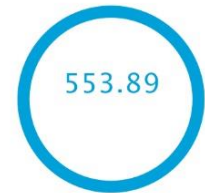

Office

$$
\begin{array}{lllll}
553.89 \mathrm{kWh} / \mathrm{m}^{2} / \mathrm{yr} & \text { Electricity } & ¥ 1471763.23 / \mathrm{yr} & 2030 & 1660.4 \\
& \text { Natural Gas } & ¥ 2929622.01 / \mathrm{yr} & \text { Baseline } & \text { Tonne/CO2e/yr } \\
& & & \text { Emissions } & 2991.7 \\
& & \text { You Saved } & \text { Tonne/CO2e/yr } & 0 \text { Trucks of Icelyr @ }
\end{array}
$$

OpenStudio Export

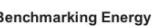

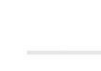
BASELINE 307.42

TARGET 61.48

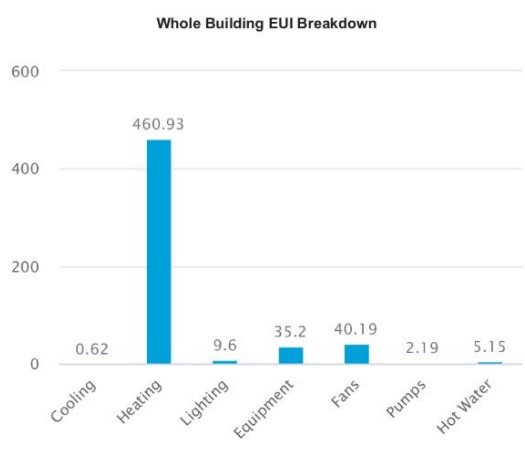

Figure A35. Zone 6-B Ordos, Nei Menggu (post-COVID-19 78\% scenario).

Baseline Energy $\odot$
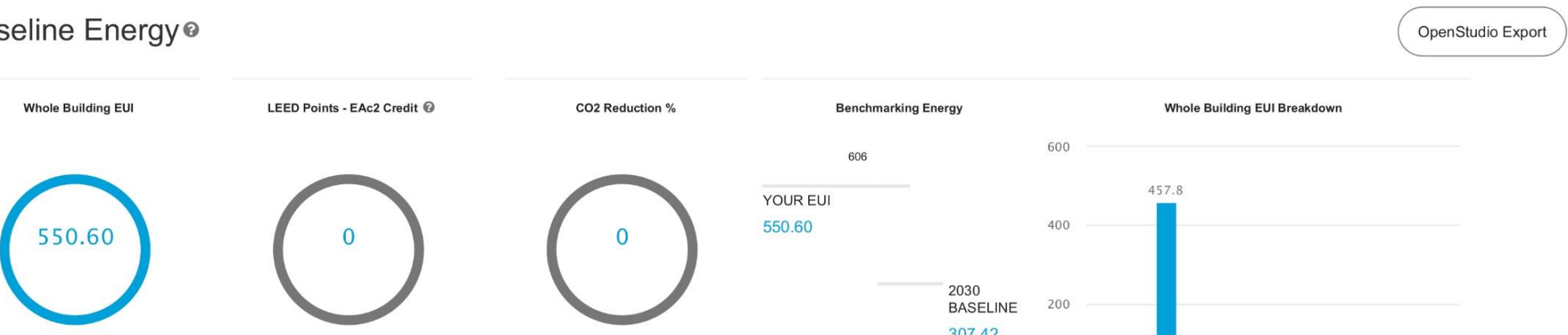

LEED Points - EAc2 Credit @

Co2 Reduction \%

Benchmarking Energy

606
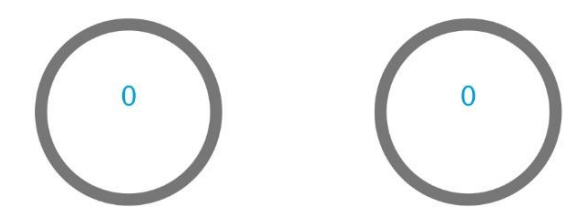

$550.6 \mathrm{kWh} / \mathrm{m}^{2} \mathrm{yr}$

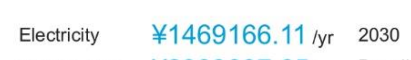

Natural Gas $¥ 2909897.65 / \mathrm{yr}$ Baseline

1661.1

Tonne/CO2e/yr

Emissions 2975.1

You Saved 0 Trucks of Ice/yr

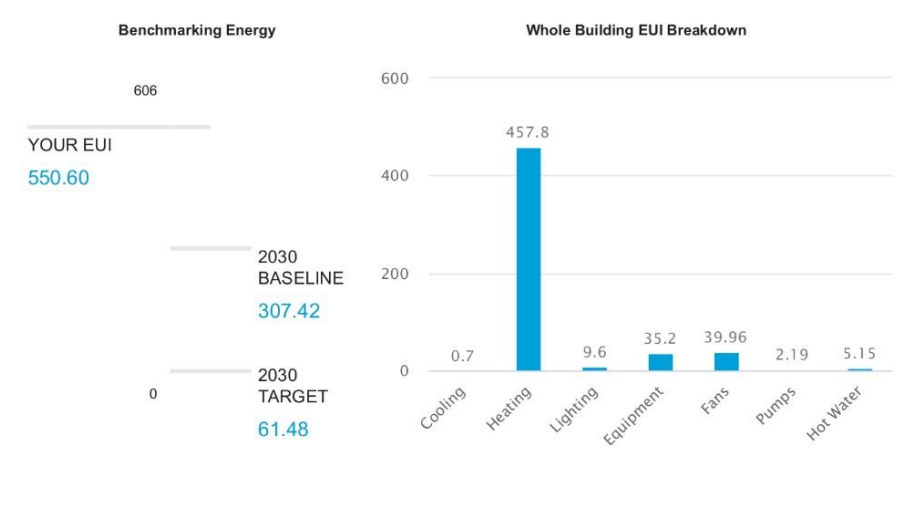

Figure A36. Zone 6-B Ordos, Nei Menggu (post-COVID-19 84\% scenario). 
Baseline Energy $\odot$

Whole Building EUI $\quad$ LEED Points - EAC2 Cred

CO2 Reduction \%
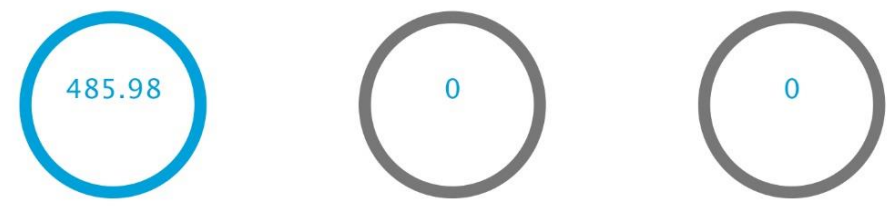

Office

$$
\begin{aligned}
& 485.98 \mathrm{kWh} / \mathrm{m}^{2} / \mathrm{yr} \quad \text { Electricity } \quad ¥ 1471118.61 / \mathrm{yr} \quad 2030 \\
& \text { Natural Gas } ¥ 2503031.46 / y r \quad \text { Baseline } \\
& 1636.3 \\
& \text { Tonne/CO2e/yr } \\
& \text { Emissions } 2659.7 \\
& \text { You Saved } 0 \text { Trecolyr }
\end{aligned}
$$
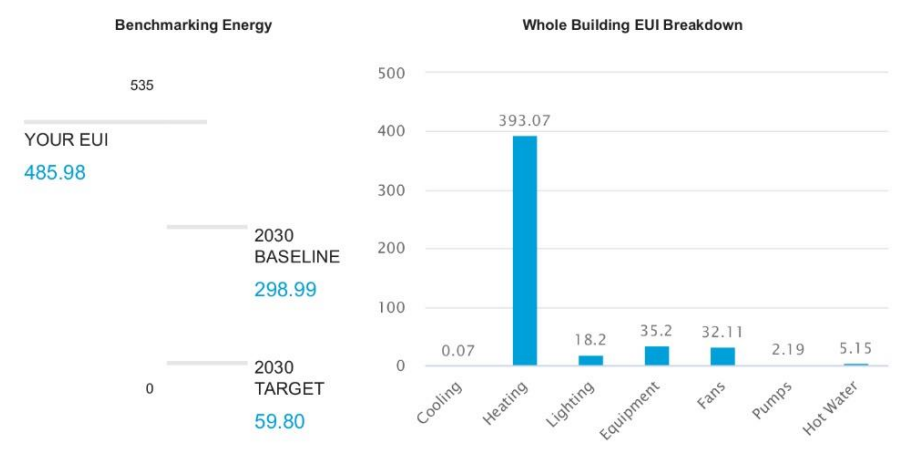

Figure A37. Zone 6-H Xi'ning, Qinghai (pre-COVID-19 scenario)

Baseline Energy $\odot$

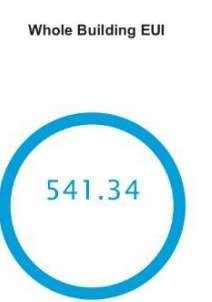

Office

$$
\begin{array}{lllll}
541.34 \mathrm{kWh} / \mathrm{m}^{2} / \mathrm{yr} & \text { Electricity } & ¥ 1417572.43 / \mathrm{yr} & \text { 2030 } & 1612.7 \\
& \text { Natural Gas } & ¥ 2871044.57 \mathrm{yr} & \text { Baseline } & \text { Tonne/CO2e/yr } \\
& & & \text { Emissions } & 2919.8 \\
& & & \text { Tonne/CO2e/yr } \\
& & & \text { You Saved } & \text { O Trucks of Ice/yr @ }
\end{array}
$$

Figure A38. Zone 6-H Xi'ning, Qinghai (post-COVID-19 78\% scenario). 
Baseline Energy $\odot$
LEED Points - EAC2 Credit \&

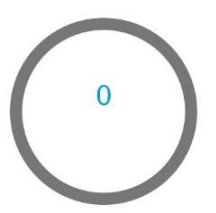

$537.62 \mathrm{kWh} / \mathrm{m}^{2} / \mathrm{yr}$

$$
\begin{array}{llll}
\text { Electricity } & ¥ 1413683.74 / \mathrm{yr} & 2030 & 1613.3 \\
\text { Natural Gas } & ¥ 2849147.4 / \mathrm{yr} & \text { Baseline } & \text { Tonne/CO2e/yr } \\
& & \text { Emissions } & 2900.9 \\
& & & \text { Tonne/CO2e/yr }
\end{array}
$$

OpenStudio Export
Benchmarking Energy

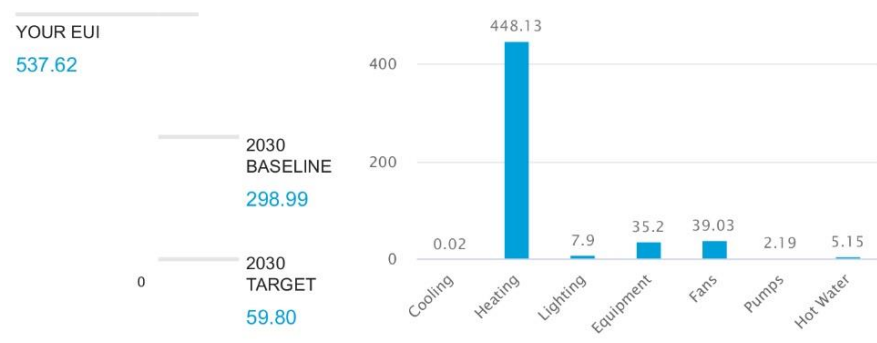

Figure A39. Zone 6-H Xi'ning, Qinghai (post-COVID-19 84\% scenario)
Baseline Energye

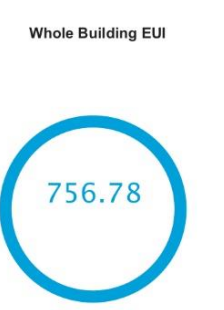

Office
LEED Points - EAc2 Credit @

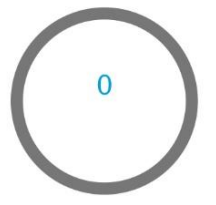

Electricity

$¥ 4096590.76 / y r$ Baseline

Emissions
You Saved 0 Trucks of Ice/yr
CO2 Reduction \%

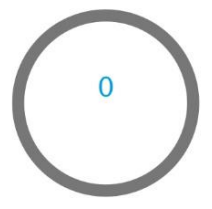

1971.5

Tonne/CO2e/yr

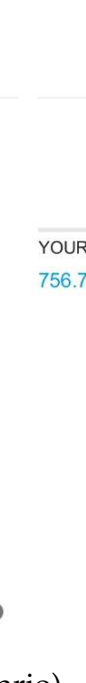

Benchmarking Energy

832

YOUR EUI

756.78

2030
BASELINE

369.38

2030
TARGET
73.88

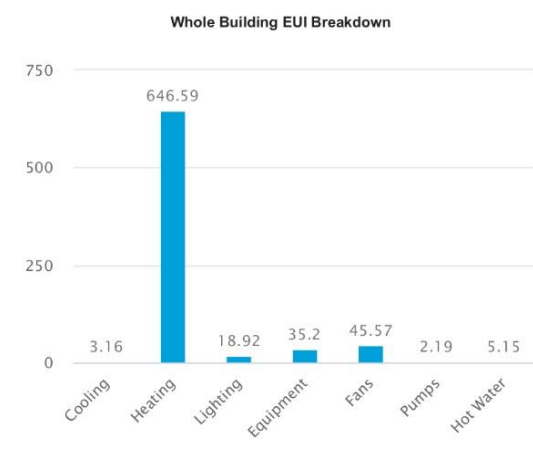

Figure A40. Zone 7 Harbin, Heilongjiang (pre-COVID-19 scenario). 
Baseline Energy $\odot$

Whole Building EU

LEED Points - EAC2 Credit @

co2 Reduction $\%$

Benchmarking Energy
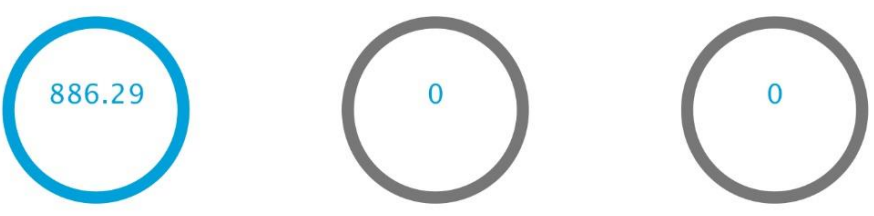

$886.29 \mathrm{kWh} / \mathrm{m}^{2} / \mathrm{s}$

$¥ 1896433.34 / y r \quad 2030$

1958.1

Natural Gas $¥ 4859711.72 / y r \quad$ Baseline $\quad$ Tonne/CO2e/yr

You Saved 0 Trucks of Icelyr
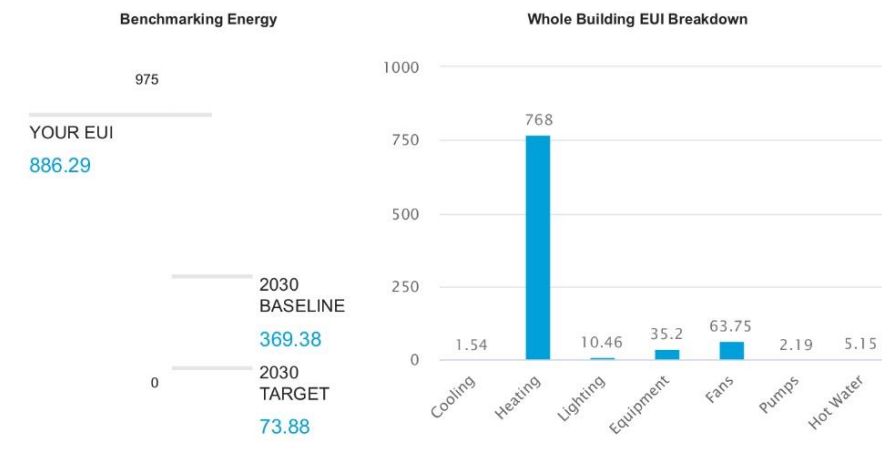

Figure A41. Zone 7 Harbin, Heilongjiang (post-COVID-19 78\% scenario).

Baseline Energy $\odot$

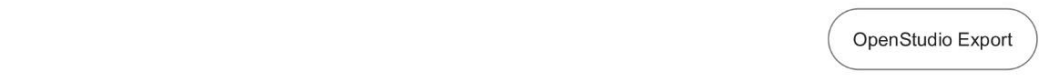

LEED Points - EAc2 Credit @

CO2 Reduction \%
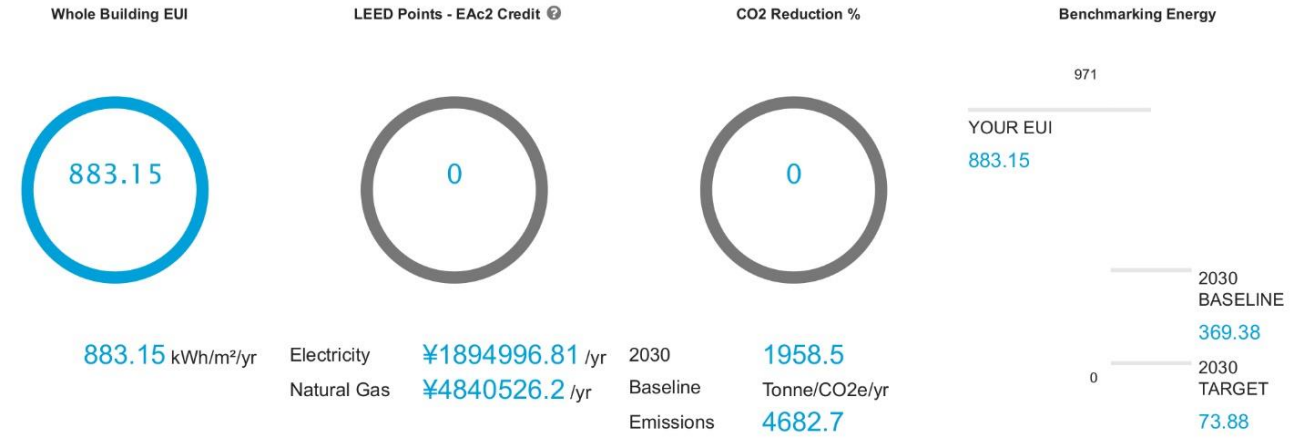

Electricity $¥ 1894996.81 / \mathrm{yr} \quad 2030$

1958.5

Baseline

Tonne/CO2e/y

You Saved 0 Trucks of Ieelyr

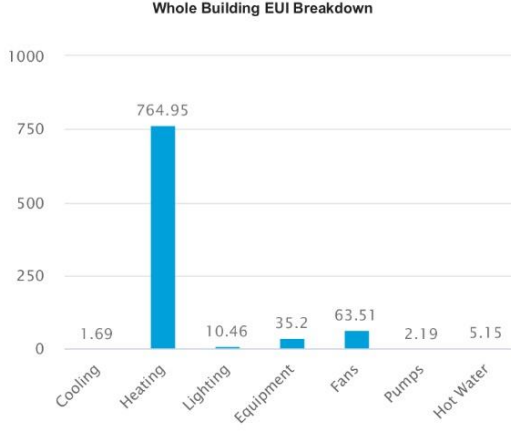

Figure A42. Zone 7 Harbin, Heilongiiang (post-COVID-19 84\% scenario). 


\section{Baseline Energy ${ }^{\circ}$}

Whole Building EUI

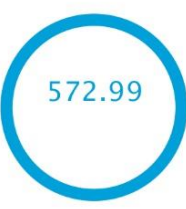

Office

$572.99 \mathrm{kWh} / \mathrm{m}^{2} / \mathrm{rr}$
LEED Points - EAC2 Credit @

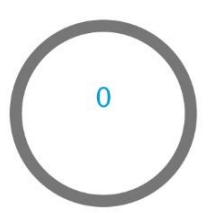

$¥ 1564043.21 / \mathrm{yr} \quad 2030$

$¥ 3015071.72 / y r \quad$ Baseline

Emission

You Save
CO2 Reduction \%

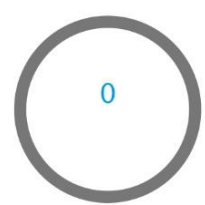

1911.4

Tonne/CO2e//

0 Trucks of Ice/yr

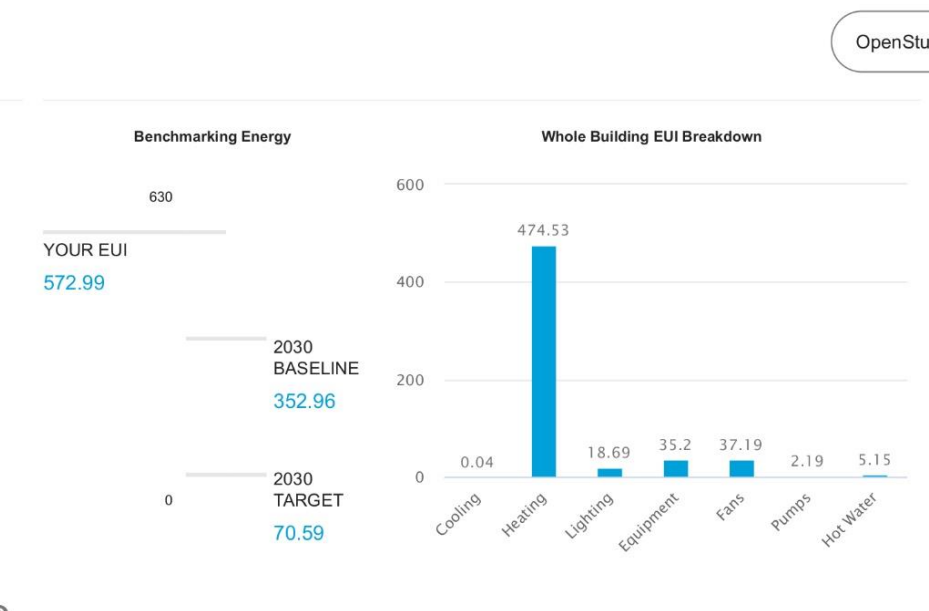

Figure A43. Zone 7-H Delinghá, Qinghai (pre-COVID-19 scenario).

Baseline Energy $\odot$

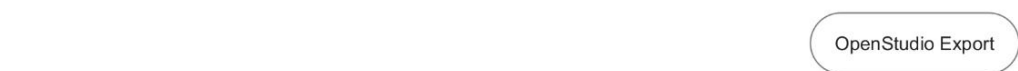

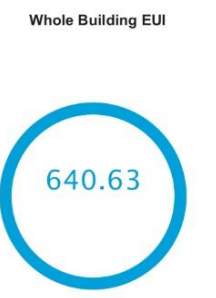

$640.63 \mathrm{kWh} / \mathrm{m}^{2} / \mathrm{s}$
LEED Points - EAc2 Crodit @

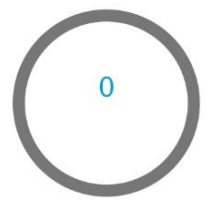

Electricity $¥ 3442594.25 / y r \quad$ Baseline

Emission

$\begin{array}{ll}\text { You Saved } & 0 \text { Trucks of Ice/yr } 8\end{array}$
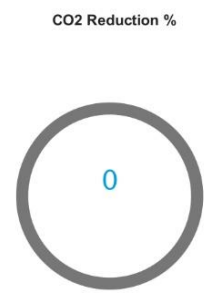

1891

Tonne/CO2e/yr
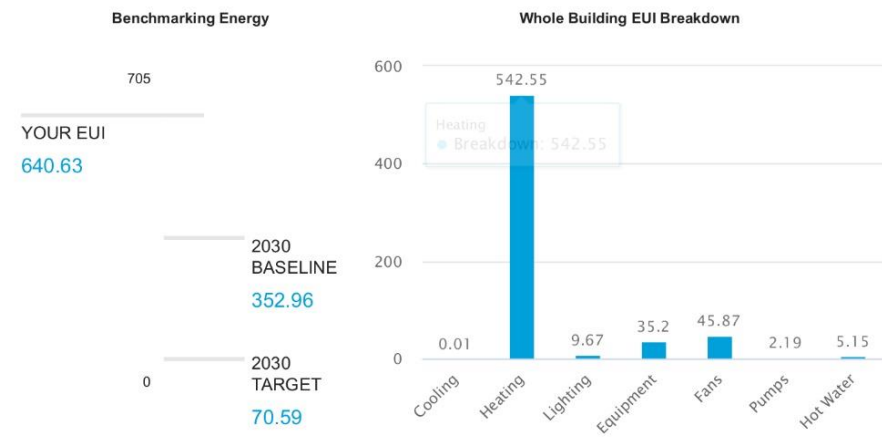

Figure A44. Zone 7-H Delinghá, Qinghai (post-COVID-19 78\% scenario). 
Baseline Energy $\odot$

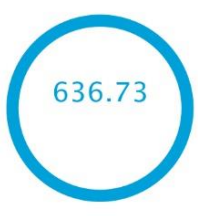

Office

$$
\begin{array}{lllll}
636.73 \mathrm{kWh} / \mathrm{m}^{2} / \mathrm{yr} & \text { Electricity } & ¥ 1553796.67 / \mathrm{yr} & \text { 2030 } & 1891.6 \\
& \text { Natural Gas } & ¥ 3419567.07 / \mathrm{yr} & \text { Baseline } & \text { Tonne/Co2e//yr } \\
& & & \text { Emissions } & 3412.4 \\
& & & \text { Tonne/CO2e/yr }
\end{array}
$$

Co2 Reduction \%

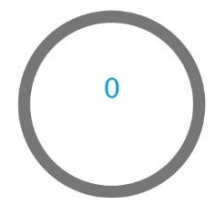

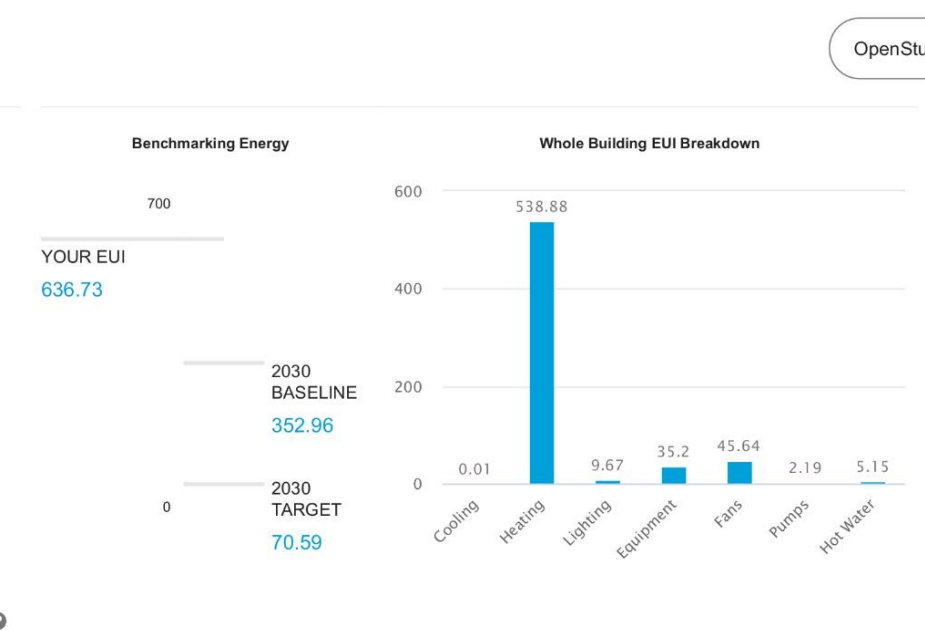

OpenStudio Export

Figure A45. Zone 7-H Delinghá, Qinghai (post-COVID-19 84\% scenario)

Baseline Energye

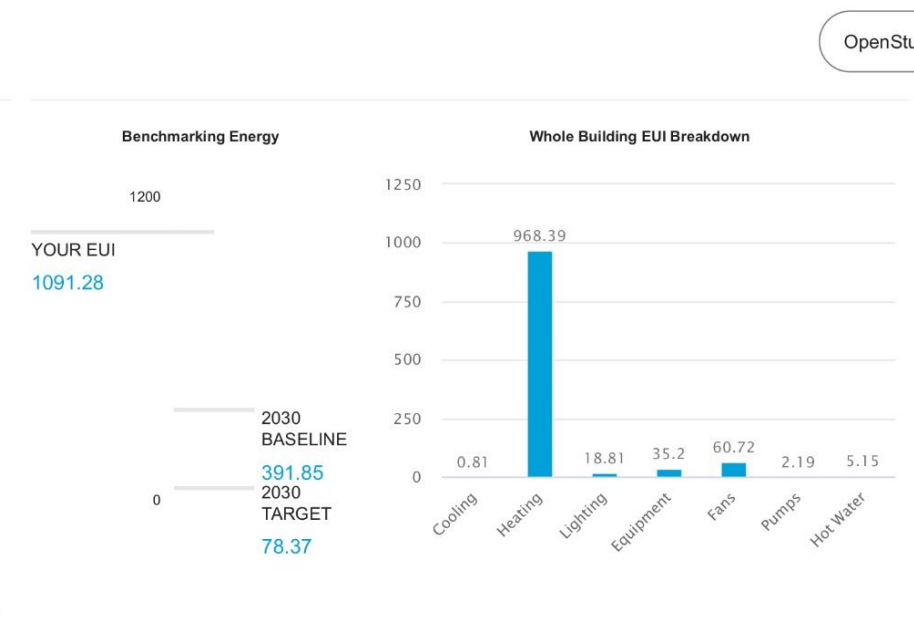

Figure A46. Zone 8 Tahé, Heilongjiang (pre-COVID-19 scenario). 
Baseline Energy ${ }^{8}$

LEED Points - EAc2 Credit

CO2 Reduction \%
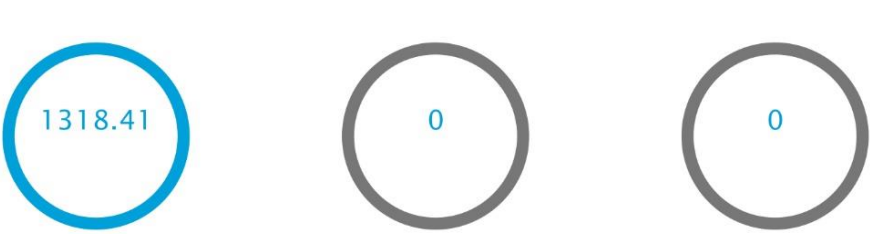

Office

$$
\begin{aligned}
& 1318.41 \\
& \text { Electricity } \\
& ¥ 2375120.58 / \mathrm{yr} \quad 2030 \\
& 2051.6 \\
& \mathrm{kWh} / \mathrm{m}^{2} / \mathrm{yr} \\
& \text { Natural Gas } ¥ 7396338.93 / y r \quad \text { Baseline } \\
& \begin{array}{l}
\text { Tonne/CO2e/yr } \\
69027
\end{array} \\
& \text { Tonne/CO2e/yr }
\end{aligned}
$$

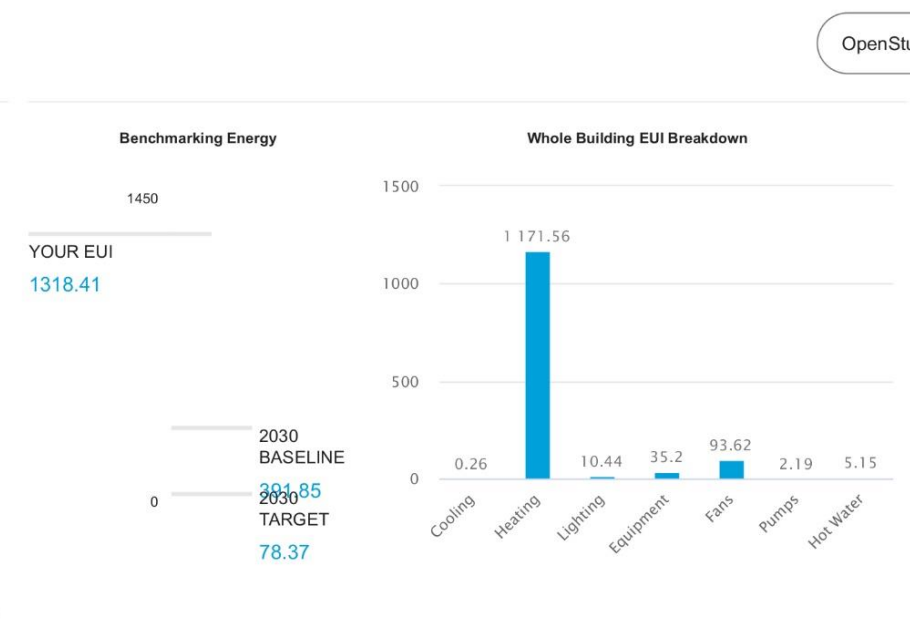

Figure A47. Zone 8 Tahé, Heilongjiang (post-COVID-19 78\% scenario).

Baseline Energy ${ }^{\odot}$

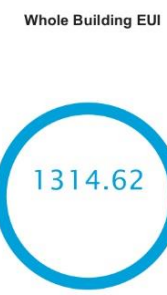

Office

$$
\begin{array}{lllll}
1314.62 & \text { Electricity } & ¥ 2371940.61 / \mathrm{yr} & \text { 2030 } & 2051.8 \\
\mathrm{kWh} / \mathrm{m}^{2} / \mathrm{yr} & \text { Natural Gas } & ¥ 7373725.51 / \mathrm{yr} & \text { Baseline } & \text { Tonne/CO2e/yr } \\
& & & \text { Emissions } & 6883.6 \\
& & & \text { Tonne/CO2e/yr } \\
& & & \text { You Saved } & 0 \text { Trucks of Ice/yr } \text { O }
\end{array}
$$

Figure A48. Zone 8 Tahé, Heilongjiang (post-COVID-19 84\% scenario).

DenStudio Export 


\section{Baseline Energy 8}

Whole Building EUI

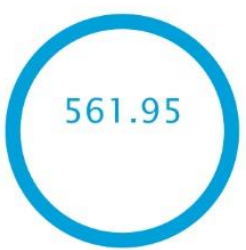

Office $561.95 \mathrm{kWh} / \mathrm{m}^{2} / \mathrm{yr}$
LEED Points - EAc2 Credit 0

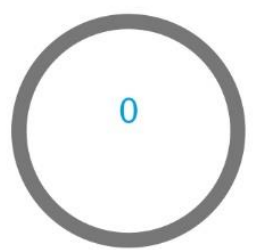

$\begin{array}{lll}\text { Electricity } & ¥ 1530892.96 / \mathrm{yr} & 2030 \\ \text { Natural Gas } & ¥ 2958116.89 / \mathrm{yr} & \text { Baseline }\end{array}$
Emissions

CO2 Reduction \%

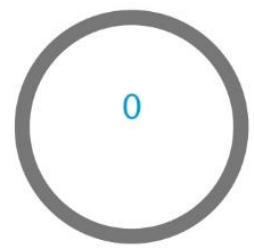

1921.1

Tonne/CO2e/y

3042.5

Tonne/CO2e/yr

You Saved 0 Trucks of Icelyr 8

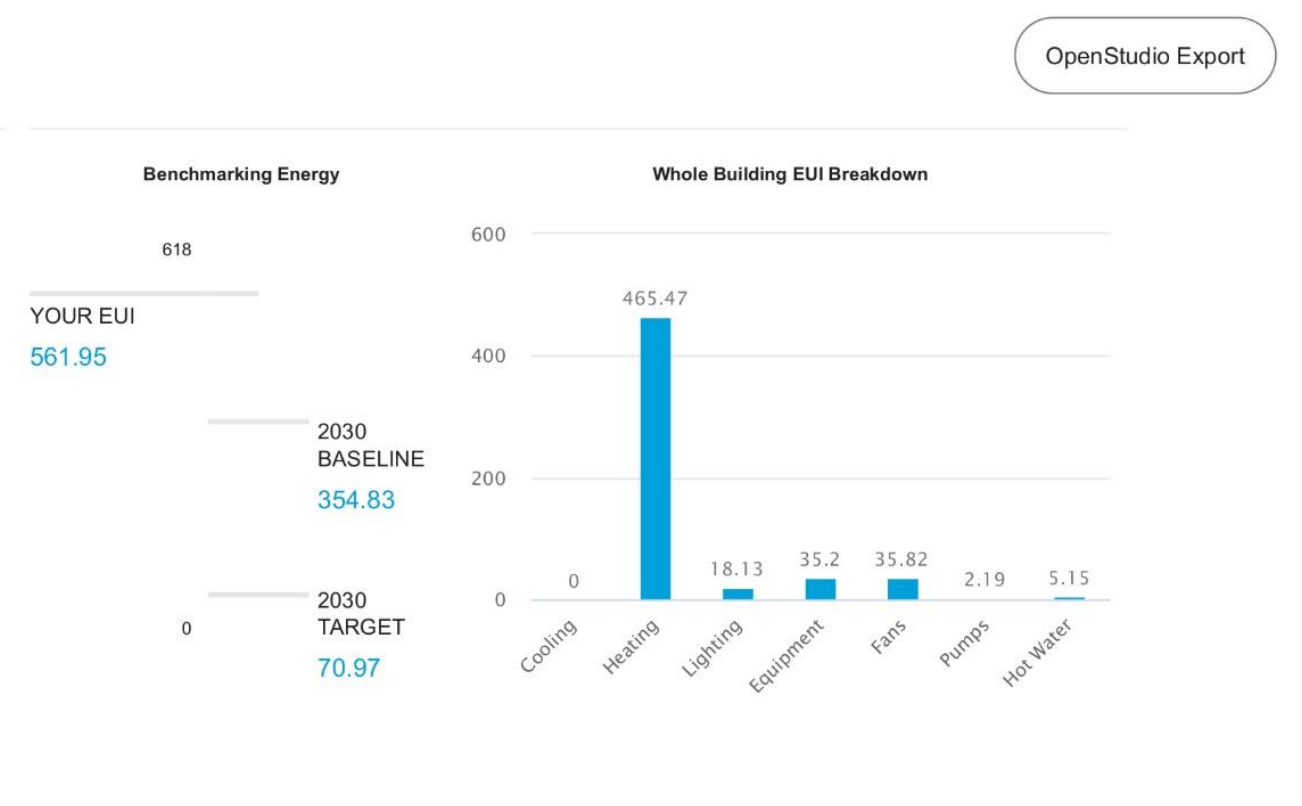

Figure A49. Zone 8-H Yushu, Qinghai (pre-COVID-19 scenario) 


\section{Baseline Energy ${ }^{8}$}

LEED Points - EAc2 Credit $\odot$

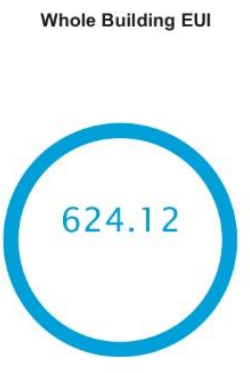

Office

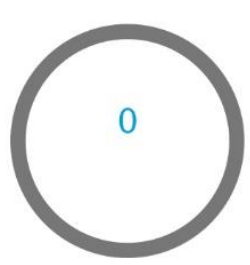

$\begin{array}{lll}\text { Electricity } & ¥ 1512713.53 / \mathrm{yr} & 2030 \\ \text { Natural Gas } & ¥ 3355704.52 / \mathrm{yr} & \text { Baseline } \\ & & \text { Emissions }\end{array}$

You Saved
CO2 Reduction $\%$

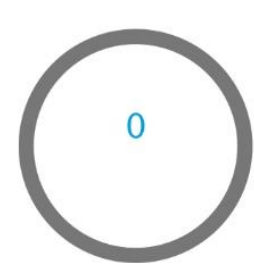

1900.5

Tonne/CO2e/yr

3342.8

Tonne/CO2e/yr

0 Trucks of Ice/yr

Figure A50. Zone 8-H Yushu, Qinghai (post-COVID-19 78\% scenario).

OpenStudio Export

Benchmarking Energy

YOUR EU

624.12

2030

BASELINE

2030

70.97
Whole Building EUI Breakdown

400

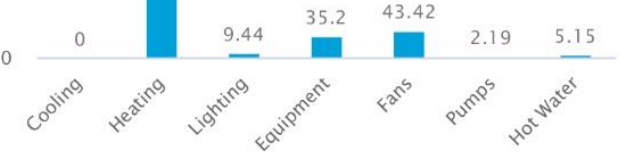




\section{Baseline Energy ${ }^{\bullet}$}

LEED Points - EAc2 Credit 9

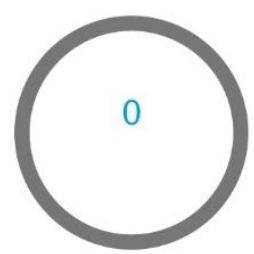

Electricity $¥ 1508206.67 / \mathrm{yr} \quad 2030$ Natural Gas $\quad ¥ 3327692.86 / y r \quad$ Baseline

Emissions

You Saved

901.3

Tonne/CO2e/y

3318.9

Tonne/CO2e/yr

0 Trucks of Ice/yr e

Figure A51. Zone 8-H Yushu, Qinghai (post-COVID-19 84\% scenario).

OpenStudio Export

Benchmarking Energy

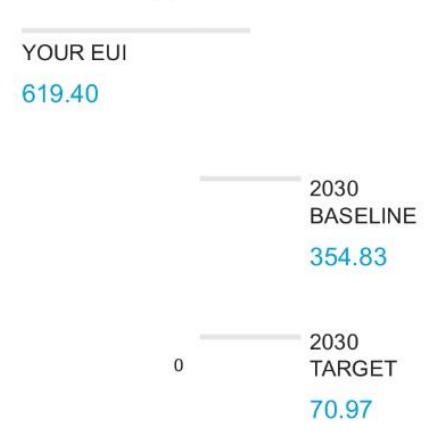

600

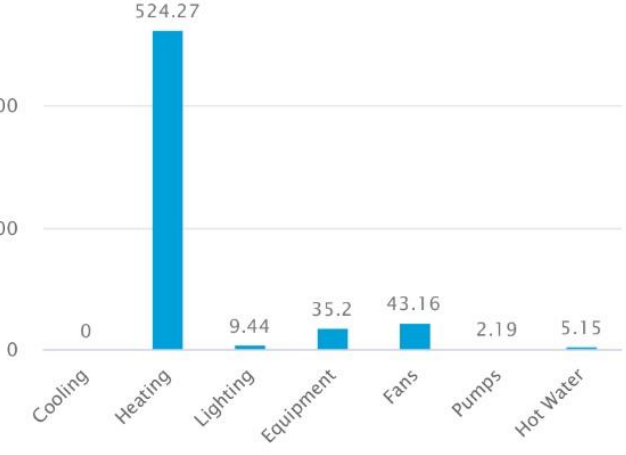

Whole Building EUI Breakdown
619.40

$619.4 \mathrm{kWh} / \mathrm{m}^{2} / \mathrm{yr}$ 
Appendix B.2. Results

Appendix B.2.1. Disaggregated EUI and Total Usable Energy Consumption

Table A3. Pre-and post-C19 scenario EUI results by location in $\mathrm{kWh} / \mathrm{m}^{2} \mathrm{yr}$.

\begin{tabular}{|c|c|c|c|c|c|c|c|c|c|c|c|c|c|c|c|c|c|c|c|c|c|c|c|c|}
\hline \multicolumn{3}{|c|}{ ASHRAE Climate Zone (29) } & \multirow{2}{*}{ City } & \multicolumn{3}{|c|}{ Cooling } & \multicolumn{3}{|c|}{ Heating } & \multicolumn{3}{|c|}{ Lighting } & \multicolumn{2}{|c|}{$\begin{array}{c}\text { Plugs and } \\
\text { Equipment }\end{array}$} & \multicolumn{3}{|c|}{ Fans } & \multicolumn{2}{|c|}{ Pumps } & \multicolumn{2}{|c|}{ swH } & \multicolumn{3}{|c|}{ Total } \\
\hline \multicolumn{2}{|c|}{$\begin{array}{l}\text { Zone, } \\
\text { Subzone }\end{array}$} & Classification & & $\begin{array}{l}\text { Pre- } \\
\mathrm{C} 19\end{array}$ & $\begin{array}{l}\text { Post- } \\
\text { C19 } \\
78 \%\end{array}$ & $\begin{array}{l}\text { Post- } \\
\text { C19 } \\
84 \%\end{array}$ & $\begin{array}{l}\text { Pre- } \\
\text { C19 }\end{array}$ & $\begin{array}{l}\text { Post- } \\
\text { C19 } \\
78 \%\end{array}$ & $\begin{array}{l}\text { Post- } \\
\text { C19 } \\
84 \%\end{array}$ & $\begin{array}{l}\text { Pre- } \\
\text { C19 }\end{array}$ & $\begin{array}{l}\text { Post- } \\
\text { C19 } \\
78 \%\end{array}$ & $\begin{array}{l}\text { Post- } \\
\text { C19 } \\
84 \%\end{array}$ & $\begin{array}{l}\text { Pre- } \\
\text { C19 }\end{array}$ & $\begin{array}{l}\text { Post- } \\
\text { C19 }\end{array}$ & $\begin{array}{l}\text { Pre- } \\
\text { C19 }\end{array}$ & $\begin{array}{c}\text { Post- } \\
\text { C19 } \\
78 \% \text { (a) }\end{array}$ & $\begin{array}{c}\text { Post- } \\
\text { C19 } \\
84 \% \text { (a) }\end{array}$ & $\begin{array}{l}\text { Pre- } \\
\mathrm{C} 19\end{array}$ & $\begin{array}{l}\text { Post- } \\
\text { C19 }\end{array}$ & $\begin{array}{l}\text { Pre- } \\
\text { C19 }\end{array}$ & $\begin{array}{l}\text { Post- } \\
\text { C19 }\end{array}$ & $\begin{array}{l}\text { Pre- } \\
\text { C19 }\end{array}$ & $\begin{array}{l}\text { Post- } \\
\text { C19 } \\
78 \%\end{array}$ & $\begin{array}{l}\text { Post- } \\
\text { C19 } \\
84 \%\end{array}$ \\
\hline 1 & A & very hot-humid & Haikou & 20.36 & 15.34 & 15.93 & 0.00 & 0.00 & 0.00 & 18.60 & 9.56 & 9.56 & 35.20 & 35.20 & 16.71 & 14.94 & 15.20 & 2.19 & 2.19 & 5.15 & 5.15 & 98.21 & 82.38 & 83.23 \\
\hline 2 & A & hot-humid & Guangzhou & 16.76 & 12.57 & 13.05 & 1.21 & 1.27 & 1.15 & 18.90 & 10.07 & 10.07 & 35.20 & 35.20 & 15.73 & 14.59 & 14.75 & 2.19 & 2.19 & 5.15 & 5.15 & 95.14 & 81.04 & 81.56 \\
\hline \multirow{2}{*}{3} & A & warm-humid & Shanghai & 8.38 & 5.90 & 6.18 & 78.52 & 96.50 & 94.65 & 18.94 & 10.31 & 10.31 & 35.20 & 35.20 & 15.07 & 16.99 & 16.97 & 2.19 & 2.19 & 5.15 & 5.15 & 163.45 & 172.24 & 170.65 \\
\hline & C & $\begin{array}{l}\text { warm-humid- } \\
\text { highland }\end{array}$ & Kunming & 1.52 & 0.58 & 0.66 & 28.47 & 38.92 & 37.64 & 18.53 & 9.57 & 9.57 & 35.20 & 35.20 & 11.87 & 13.12 & 13.09 & 2.19 & 2.19 & 5.15 & 5.15 & 102.93 & 104.73 & 103.50 \\
\hline \multirow{3}{*}{4} & A & mixed-humid & Xi'an & 8.32 & 6.10 & 6.36 & 156.52 & 186.33 & 184.18 & 18.62 & 9.61 & 9.61 & 35.20 & 35.20 & 19.82 & 23.03 & 22.95 & 2.19 & 2.19 & 5.15 & 5.15 & 245.82 & 267.61 & 265.64 \\
\hline & B & mixed-dry & Beijing & 7.80 & 5.40 & 5.66 & 235.73 & 277.96 & 275.58 & 18.90 & 10.23 & 10.23 & 35.20 & 35.20 & 24.45 & 29.47 & 29.34 & 2.19 & 2.19 & 5.15 & 5.15 & 329.42 & 365.60 & 363.35 \\
\hline & $\mathrm{H}$ & mixed-highland & Chamdo & 0.04 & 0.01 & 0.01 & 254.27 & 297.83 & 294.32 & 18.41 & 9.61 & 9.61 & 35.20 & 35.20 & 22.84 & 28.73 & 28.49 & 2.19 & 2.19 & 5.15 & 5.15 & 338.10 & 378.72 & 374.97 \\
\hline \multirow{3}{*}{5} & A & cool-humid & Shenyang & 5.26 & 3.38 & 3.58 & 391.62 & 484.74 & 481.86 & 19.34 & 10.58 & 10.58 & 35.20 & 35.20 & 31.43 & 44.24 & 44.07 & 2.19 & 2.19 & 5.15 & 5.15 & 490.19 & 585.48 & 582.63 \\
\hline & B & cool-dry & Lanzhou & 3.13 & 1.44 & 1.60 & 252.38 & 303.53 & 300.79 & 18.78 & 9.85 & 9.85 & 35.20 & 35.20 & 23.56 & 30.80 & 30.63 & 2.19 & 2.19 & 5.15 & 5.15 & 340.39 & 388.16 & 385.41 \\
\hline & $\mathrm{H}$ & cool-highland & Lhasa & 0.07 & 0.02 & 0.02 & 231.13 & 266.19 & 262.91 & 18.03 & 9.4 & 9.4 & 35.20 & 35.20 & 21.94 & 26.79 & 26.62 & 2.19 & 2.19 & 5.15 & 5.15 & 313.71 & 344.94 & 341.49 \\
\hline \multirow{3}{*}{6} & A & cold-humid & Changchun & 2.84 & 1.37 & 1.51 & 583.78 & 697.08 & 694.05 & 18.83 & 9.93 & 9.93 & 35.20 & 35.20 & 42.04 & 59.52 & 59.29 & 2.19 & 2.19 & 5.15 & 5.15 & 690.03 & 810.44 & 807.32 \\
\hline & B & cold-dry & Ordos & 1.56 & 0.62 & 0.7 & 392.96 & 460.93 & 457.8 & 18.53 & 9.6 & 9.6 & 35.20 & 35.20 & 31.48 & 41.41 & 41.18 & 2.19 & 2.19 & 5.15 & 5.15 & 487.07 & 555.10 & 551.82 \\
\hline & $\mathrm{H}$ & cold-highland & Xi'ning & 0.07 & 0.01 & 0.02 & 393.07 & 451.62 & 448.13 & 18.2 & 7.9 & 7.9 & 35.20 & 35.20 & 32.11 & 40.49 & 40.25 & 2.19 & 2.19 & 5.15 & 5.15 & 485.99 & 542.56 & 538.84 \\
\hline \multirow{2}{*}{7} & - & very cold & Harbin & 3.16 & 1.54 & 1.69 & 646.59 & 768 & 764.95 & 18.92 & 10.46 & 10.46 & 35.20 & 35.20 & 45.57 & 64.97 & 64.73 & 2.19 & 2.19 & 5.15 & 5.15 & 756.78 & 887.51 & 884.37 \\
\hline & $\mathrm{H}$ & very cold-highland & Delinghá & 0.04 & 0.01 & 0.01 & 474.53 & 542.55 & 538.88 & 18.69 & 9.67 & 9.67 & 35.20 & 35.20 & 37.19 & 47.09 & 46.86 & 2.19 & 2.19 & 5.15 & 5.15 & 572.99 & 641.86 & 637.96 \\
\hline \multirow{2}{*}{8} & - & subarctic & Tahé & 0.81 & 0.26 & 0.3 & 968.39 & 1171.56 & 1167.96 & 18.81 & 10.44 & 10.44 & 35.20 & 35.20 & 60.72 & 94.84 & 94.6 & 2.19 & 2.19 & 5.15 & 5.15 & 1091.27 & 1319.64 & 1315.84 \\
\hline & $\mathrm{H}$ & subarctic-highland & Yushu & 0 & 0 & 0 & 465.47 & 528.72 & 524.27 & 18.13 & 9.44 & 9.44 & 35.20 & 35.20 & 35.82 & 44.64 & 44.38 & 2.19 & 2.19 & 5.15 & 5.15 & 561.96 & 625.34 & 620.63 \\
\hline
\end{tabular}

(a) Additional energy consumption of $1.22 \mathrm{~kW} / \mathrm{m}^{2} \mathrm{yr}$ due to filter upgrade (MERV8 to 14) in post-C19. 
Table A4. Usable energy consumption per location $\left(\mathrm{kWh} / \mathrm{m}^{2} \mathrm{yr}\right)$ in pre- and post-C19 scenarios.

\begin{tabular}{|c|c|c|c|c|c|c|c|}
\hline \multirow{2}{*}{ Climate Zone, City } & \multicolumn{3}{|c|}{ Total $\left(\mathrm{kWh} / \mathrm{m}^{2} \mathrm{yr}\right)$} & \multicolumn{2}{|c|}{ Variation Difference (\%) } & \multicolumn{2}{|c|}{ Variation Difference $\left(\mathrm{kWh} / \mathrm{m}^{2} \mathrm{yr}\right)$} \\
\hline & Pre-C19 & Post-C19 78\% & Post-C19 84\% & Post-C19 78\% & Post-C19 84\% & Post-C19 78\% & Post-C19 84\% \\
\hline 1-A, Haikou & 98.21 & 82.38 & 83.23 & $-16.12 \%$ & $-15.25 \%$ & -15.83 & -14.98 \\
\hline 2-A, Guangzhou & 95.14 & 81.04 & 81.56 & $-14.82 \%$ & $-14.27 \%$ & -14.10 & -13.58 \\
\hline 3-A, Shanghai & 163.45 & 172.24 & 170.65 & $+5.38 \%$ & $+4.41 \%$ & +8.79 & +7.20 \\
\hline 3-C, Kunming & 102.93 & 104.73 & 103.50 & $+1.75 \%$ & $+0.55 \%$ & +1.80 & +0.57 \\
\hline 4-A, Xi'an & 245.82 & 267.61 & 265.64 & $+8.86 \%$ & $+8.06 \%$ & +21.79 & +19.82 \\
\hline 4-B, Beijing & 329.42 & 365.60 & 363.35 & $+10.98 \%$ & $+10.30 \%$ & +36.18 & +33.93 \\
\hline 4-H, Chamdo & 338.10 & 378.72 & 374.97 & $+12.01 \%$ & $+10.91 \%$ & +40.62 & +36.87 \\
\hline 5-B, Lanzhou & 340.39 & 388.16 & 385.41 & $+14.03 \%$ & $+13.23 \%$ & +47.77 & +45.02 \\
\hline 5-H, Lhasa & 313.71 & 344.94 & 341.49 & $+9.96 \%$ & $+8.86 \%$ & +31.23 & +27.78 \\
\hline 6-A, Changchun & 690.03 & 810.44 & 807.32 & $+17.45 \%$ & $+17.00 \%$ & +120.41 & +117.29 \\
\hline 6-B, Ordos & 487.07 & 555.10 & 551.82 & $+13.97 \%$ & $+13.29 \%$ & +68.03 & +64.75 \\
\hline 6-H, Xi'ning & 485.99 & 542.56 & 538.84 & $+11.64 \%$ & $+10.87 \%$ & +56.57 & +52.85 \\
\hline 7, Harbin & 756.78 & 887.51 & 884.37 & $+17.27 \%$ & $+16.86 \%$ & +130.73 & +127.59 \\
\hline 7-H, Delinghá & 572.99 & 641.86 & 637.96 & $+12.02 \%$ & $+11.34 \%$ & +68.87 & +64.97 \\
\hline 8 , Tahé & 1091.27 & 1319.64 & 1315.84 & $+20.93 \%$ & $+20.58 \%$ & +228.37 & +224.57 \\
\hline 8-H, Yushu & 561.96 & 625.34 & 620.63 & $+11.28 \%$ & $+10.44 \%$ & +63.38 & +58.67 \\
\hline
\end{tabular}




\section{Appendix B.2.2. Energy Costs}

Table A5. Chinese standard office building energy costs comparison on pre- and post-C19 scenario by location.

\begin{tabular}{|c|c|c|c|c|c|c|c|c|c|c|c|c|c|c|c|c|c|c|c|c|}
\hline \multirow{3}{*}{$\begin{array}{l}\text { Climate Zone, } \\
\text { City }\end{array}$} & \multirow{2}{*}{\multicolumn{2}{|c|}{$\begin{array}{l}\text { Energy Prices } \\
\text { (USD/kWh) }\end{array}$}} & \multirow{2}{*}{\multicolumn{3}{|c|}{ Total $\left(\mathbf{k W h} / \mathbf{m}^{2} \mathbf{y r}\right)$}} & \multirow{2}{*}{\multicolumn{2}{|c|}{$\begin{array}{c}\text { Variation Difference } \\
\left.\text { (kWh/m } \mathbf{m}^{2} \mathrm{yr}\right)\end{array}$}} & \multicolumn{6}{|c|}{ EUI (Fuel) $\left(\mathrm{kWh} / \mathrm{m}^{2} \mathrm{yr}\right)$} & \multirow{2}{*}{\multicolumn{3}{|c|}{ Cost (USD/kWh/yr) }} & \multicolumn{4}{|c|}{ Cost Difference } \\
\hline & & & & & & & & \multicolumn{2}{|c|}{ Pre-C19 } & \multicolumn{2}{|c|}{ Post-C19 78\% } & \multicolumn{2}{|c|}{ Post-C19 84\% } & & & & \multicolumn{2}{|c|}{ (USD/kWh/yr) } & \multicolumn{2}{|c|}{$(\%)$} \\
\hline & N.Gas & Electricity & $\begin{array}{l}\text { Pre- } \\
\text { C19 }\end{array}$ & $\begin{array}{c}\text { Post-C19 } \\
78 \% \\
\end{array}$ & $\begin{array}{c}\text { Post-C19 } \\
84 \%\end{array}$ & $\begin{array}{l}\text { Post-C19 } \\
78 \%\end{array}$ & $\begin{array}{c}\text { Post-C19 } \\
84 \%\end{array}$ & N.Gas & Electricity & N.Gas & Electricity & N.Gas & Electricity & $\begin{array}{l}\text { Pre- } \\
\text { C19 }\end{array}$ & $\begin{array}{l}\text { Post-C19 } \\
78 \%\end{array}$ & $\begin{array}{c}\text { Post-C19 } \\
84 \%\end{array}$ & $\begin{array}{l}\text { Post-C19 } \\
78 \%\end{array}$ & $\begin{array}{c}\text { Post-C19 } \\
84 \%\end{array}$ & $\begin{array}{l}\text { Post-C19 } \\
78 \%\end{array}$ & $\begin{array}{c}\text { Post-C19 } \\
84 \%\end{array}$ \\
\hline 2-A, Guangzhou & 0.045 & 0.108 & 95.14 & 81.04 & 81.56 & -14.10 & -13.58 & 6.36 & 88.78 & 6.42 & 74.62 & 6.30 & 75.26 & 9.87 & 8.35 & 8.41 & -1.53 & -1.46 & $-15.46 \%$ & $-14.82 \%$ \\
\hline 3-A, Shanghai & 0.045 & 0.116 & 163.45 & 172.24 & 170.65 & +8.79 & +7.20 & 83.67 & 79.78 & 101.65 & 70.59 & 99.80 & 70.85 & 12.95 & 12.69 & 12.64 & -0.26 & -0.31 & $-1.99 \%$ & $-2.40 \%$ \\
\hline 3-C, Kunming & 0.039 & 0.090 & 102.93 & 104.73 & 103.50 & +1.80 & +0.57 & 33.62 & 69.31 & 44.07 & 60.66 & 42.79 & 60.71 & 7.53 & 7.16 & 7.11 & -0.38 & -0.42 & $-4.98 \%$ & $-5.58 \%$ \\
\hline $4-\mathrm{A}, \mathrm{X}^{\prime}{ }^{\prime} \mathrm{n}$ & 0.031 & 0.101 & 245.82 & 267.61 & 265.64 & +21.79 & +19.82 & 161.67 & 84.15 & 191.48 & 76.13 & 189.33 & 76.31 & 13.43 & 13.54 & 13.49 & +0.11 & +0.06 & $+0.82 \%$ & $+0.47 \%$ \\
\hline 4-B, Beijing & 0.041 & 0.122 & 329.42 & 365.60 & 363.35 & +36.18 & +33.93 & 240.88 & 88.54 & 283.11 & 82.49 & 280.73 & 82.62 & 20.62 & 21.61 & 21.53 & +0.99 & +0.91 & $+4.82 \%$ & $+4.42 \%$ \\
\hline 5-A, Shenyang & 0.041 & 0.107 & 490.19 & 585.48 & 582.63 & +95.29 & +92.44 & 396.77 & 93.42 & 489.89 & 95.59 & 487.01 & 95.62 & 26.20 & 30.24 & 30.12 & +4.04 & +3.93 & $+15.44 \%$ & $+15.00 \%$ \\
\hline 5-B, Lanzhou & 0.033 & 0.102 & 340.39 & 388.16 & 385.41 & +47.77 & +45.02 & 257.53 & 82.86 & 308.68 & 79.48 & 305.94 & 79.47 & 17.06 & 18.43 & 18.34 & +1.37 & +1.27 & $+8.00 \%$ & $+7.46 \%$ \\
\hline 5-H, Lhasa & 0.029 & 0.102 & 313.71 & 344.94 & 341.49 & +31.23 & +27.78 & 236.28 & 77.43 & 271.34 & 73.60 & 268.06 & 73.43 & 14.68 & 15.29 & 15.18 & +0.62 & +0.50 & $+4.19 \%$ & $+3.43 \%$ \\
\hline 6-A, Changchun & 0.039 & 0.117 & 690.03 & 810.44 & 807.32 & +120.41 & +117.29 & 588.93 & 101.10 & 702.23 & 108.21 & 699.20 & 108.12 & 34.54 & 39.74 & 39.61 & +5.20 & +5.07 & $+15.06 \%$ & $+14.69 \%$ \\
\hline 6-B, Ordos & 0.031 & 0.084 & 487.07 & 555.10 & 551.82 & +68.03 & +64.75 & 398.11 & 88.96 & 466.08 & 89.02 & 462.95 & 88.87 & 19.71 & 21.81 & 21.70 & +2.09 & +1.99 & $+10.63 \%$ & $+10.07 \%$ \\
\hline 6-H, Xi'ning & 0.030 & 0.077 & 485.99 & 542.56 & 538.84 & +56.57 & +52.85 & 398.22 & 87.77 & 456.77 & 85.79 & 453.28 & 85.56 & 18.67 & 20.28 & 20.16 & +1.61 & +1.48 & $+8.60 \%$ & $+7.95 \%$ \\
\hline 7, Harbin & 0.031 & 0.111 & 756.78 & 887.51 & 884.37 & +130.73 & +127.59 & 651.74 & 105.04 & 773.15 & 114.36 & 770.10 & 114.27 & 31.70 & 36.46 & 36.36 & +4.77 & +4.66 & $+15.04 \%$ & $+14.71 \%$ \\
\hline 7-H, Delinghá & 0.030 & 0.077 & 572.99 & 641.86 & 637.96 & +68.87 & +64.97 & 479.68 & 93.31 & 547.70 & 94.16 & 544.03 & 93.93 & 21.54 & 23.65 & 23.52 & +2.11 & +1.98 & $+9.78 \%$ & $+9.19 \%$ \\
\hline 8, Tahé & 0.031 & 0.111 & 1091.27 & 1319.64 & 1315.84 & +228.37 & +224.57 & 973.54 & 117.73 & 1176.71 & 142.93 & 1173.11 & 142.73 & 43.00 & 52.04 & 51.91 & +9.04 & +8.91 & $+21.03 \%$ & $+20.72 \%$ \\
\hline 8-H, Yushu & 0.030 & 0.077 & 561.96 & 625.34 & 620.63 & +63.38 & +58.67 & 470.62 & 91.34 & 533.87 & 91.47 & 529.42 & 91.21 & 21.12 & 23.03 & 22.87 & +1.91 & +1.76 & $+9.04 \%$ & $+8.31 \%$ \\
\hline
\end{tabular}

(a) Due to the lack of information, the research team adopted the average business electricity prices of USD 0.102 . 


\section{References}

1. Reuters Staff Factbox: The Origins of COVID-19/Reuters. Available online: https://www.reuters.com/article/us-healthcoronavirus-who-china-factbox-idUSKBN29O08P (accessed on 11 March 2021).

2. WHO Archived: WHO Timeline-COVID-19. Available online: https://www.who.int/news/item/27-04-2020-who-timeline--covid-19 (accessed on 11 March 2021).

3. Singh, K. China Coronavirus: Half a Billion Chinese Now in Confinement in Bid to Halt Killer Virus. Available online: https://inews.co.uk/news/world/china-coronavirus-chinese-confinement-lockdown-wuhan-containment-398066 (accessed on 11 March 2021).

4. Life after Lockdown: How China Went Back to Work. BBC Worklife, 1 May 2020.

5. Guo, B.M.; Xu, P.; Xiao, T.; He, R.; Dai, M.; Miller, S.L. Review and comparison of HVAC operation guidelines in different countries during the COVID-19 pandemic. Build. Environ. 2021, 187, 107368. [CrossRef] [PubMed]

6. Lewis, D. Is the coronavirus airborne? Experts can't agree. Nature 2020, 580, 175. [CrossRef] [PubMed]

7. Morawska, L.; Cao, J. Airborne transmission of SARS-CoV-2: The world should face the reality. Environ. Int. 2020, 139, 105730. [CrossRef] [PubMed]

8. Chinese Association of Refrigeration (CAR). Suggestions on the Safe Use of Air Conditioning (Heating) in Response to the New Corona Pneumonia Epidemic after Work during the Spring Festival. Available online: http:/ /www.car.org.cn/index.php?s= /articles_1348.html (accessed on 25 March 2021).

9. World Health Organization (WHO). Roadmap to Improve and Ensure Good Indoor Ventilation in the Context of COVID-19; World Health Organization: Geneva, Switzerland, 2021; ISBN 978-92-4-002128-0.

10. World Health Organization (WHO). Getting Your Workplace Ready for COVID-19: How COVID-19 Spreads; Schools, Businesses and Institutions: Geneva, Switzerland, 2020.

11. World Health Organization (WHO). Considerations for Public Health and Social Measures in the Workplace in the Context of COVID-19 (Annex); World Health Organization and ILO's LabAdmin/OSH Branch: Geneva, Switzerland, 2020.

12. Global Heat Health Information Network. Do Air Conditioning and Ventilation Systems Increase the Risk of Virus Transmis-sion? If So, How Can This Be Managed? Available online: https://ghhin.org/faq/do-air-conditioning-and-ventilation-systemsincrease-the-risk-of-virus-transmission-if-so-how-can-this-be-managed/ (accessed on 15 April 2021).

13. China Construction Technology Group Co., Ltd. Guide to Emergency Measures for Operation Management of Office Buildings in Response to the "New Coronavirus"; Architectural Society of China (ASC): Beijing, China, 2020.

14. People's Medical Publishing House (PMPH). Guidance for Corona Virus Disease 2019: Prevention, Control, Diagnosis and Management; National Health Commission (NHC): Beijing, China, 2020; ISBN 978-7-117-29817-9.

15. Chinese Center for Disease Control and Prevention. Guideline on Operation Management and Use of Air Conditioners in Summer; Chinese Center for Disease Control and Prevention: Beijing, China, 2020.

16. American Society of Heating, Refrigerating and Air-Conditioning Engineers (ASHRAE). ASHRAE Epidemic Task Force; Building Readiness: Peachtree Corners, GA, USA, 2021.

17. Centers for Disease Control and Prevention (CDC). Guidance for Businesses and Employers Responding to Coronavirus Disease 2019 (COVID-19)_Plan, Prepare and Respond to Coronavirus Disease. 2019. Available online: https:/ /www.cdc.gov / coronavirus/2019-ncov/community/guidance-business-response.html (accessed on 19 April 2021).

18. Centers for Disease Control and Prevention (CDC). COVID-19 Employer Information for Office Buildings. Available online: https:/ / www.cdc.gov/coronavirus/2019-ncov/community/office-buildings.html (accessed on 22 March 2021).

19. Ministry of Housing and Urban-Rural Development. National Standard of the People's of China. Code for Thermal Design of Civil Building GB 50176-2016; Ministry of Housing and Urban-Rural Development: Beijing, China, 2016.

20. Zheng, W.; Hu, J.; Wang, Z.; Li, J.; Fu, Z.; Li, H.; Jurasz, J.; Chou, S.; Yan, J. COVID-19 Impact on Operation and Energy Consumption of Heating, Ventilation and Air-Conditioning (HVAC) Systems. Adv. Appl. Energy 2021, 3, 100040. [CrossRef]

21. Taylor Engineering Taylor Engineering COVID-19 White Paper. 2020. Available online: https://taylorengineers.com/wpcontent/uploads/2020/05/TE-COVID19-White-Paper.pdf (accessed on 22 March 2021).

22. Nadel, S. Reducing COVID-19 Risks in Commercial Buildings without Wasting Energy; American Council for an Energy-Efficient Economy (ACEE): Washington, DC, USA, 2020.

23. Cutler, D.M.; Summers, L.H. The COVID-19 Pandemic and the \$16 Trillion Virus. JAMA 2020, 324, 1495-1496. [CrossRef] [PubMed]

24. Mo, F.; Law, E.; Mao, M.; Pan, C.; Liu, L.; Wang, A.; Chen, S.; Lu, R.; Bazzoli, A. COVID-19 Recovery Guidelines for Buildings-China Practice; Royal Institution of Chartered Surveyors (China Regional Office): Beijing, China, 2020.

25. Omar, O. Intelligent building, definitions, factors and evaluation criteria of selection. Alex. Eng. J. 2018, 57, 2903-2910. [CrossRef]

26. Awada, M.; Becerik-Gerber, B.; White, E.; Hoque, S.; O’Neill, Z.; Pedrielli, G.; Wen, J.; Wu, T. Occupant health in buildings: Impact of the COVID-19 pandemic on the opinions of building professionals and implications on research. Build. Environ. 2021, 207, 108440. [CrossRef]

27. Feng, W.; Li, X.; Szum, C.; Zhou, N.; Bendewald, M.; Meng, Z.; Zeng, Y. From Prescriptive to Outcome-Based-The Evolution of Building Energy Codes and Standards in China. In Proceedings of the European Council for an Energy Efficient Economy's 2017 Summer Study, Hyeres, France, 29 May-3 June 2017. 
28. Ascione, F.; De Masi, R.F.; Mastellone, M.; Vanoli, G.P. The design of safe classrooms of educational buildings for facing contagions and transmission of diseases: A novel approach combining audits, calibrated energy models, building performance (BPS) and computational fluid dynamic (CFD) simulations. Energy Build. 2021, 230, 110533. [CrossRef]

29. American Society of Heating, Refrigerating and Air-Conditioning Engineers (ASHRAE). ASHRAE Offers COVID-19 Building Readiness/Reopening Guidance. Available online: https://www.ashrae.org/about/news/2020/ashrae-offers-covid-19 -building-readiness-reopening-guidance (accessed on 22 March 2021).

30. American Society of Heating, Refrigerating and Air-Conditioning Engineers (ASHRAE). Ultraviolet Air and Surface Treatment. In 2019 ASHRAE Handbook-HVAC Applications; American Society of Heating, Refrigerating and Air-Conditioning Engineers (ASHRAE): Peachtree Corners, GA, USA, 2019; Chapter 62; pp. 62.1-62.17.

31. Si, D.-K.; Li, X.-L.; Xu, X.; Fang, Y. The risk spillover effect of the COVID-19 pandemic on energy sector: Evidence from China. Energy Econ. 2021, 102, 105498. [CrossRef]

32. Cortiços, N.D.; Duarte, C.C. COVID-19: The impact in US high-rise office buildings energy efficiency. Energy Build. 2021, 249, 111180. [CrossRef]

33. Kang, H.; An, J.; Kim, H.; Ji, C.; Hong, T.; Lee, S. Changes in energy consumption according to building use type under COVID-19 pandemic in South Korea. Renew. Sustain. Energy Rev. 2021, 148, 111294. [CrossRef] [PubMed]

34. Gui, X.; Gou, Z.; Zhang, F.; Yu, R. The impact of COVID-19 on higher education building energy use and implications for future education building energy studies. Energy Build. 2021, 251, 111346. [CrossRef] [PubMed]

35. Wang, Q.; Li, S.; Jiang, F. Uncovering the impact of the COVID-19 pandemic on energy consumption: New insight from difference between pandemic-free scenario and actual electricity consumption in China. J. Clean. Prod. 2021, 313, 127897. [CrossRef]

36. Aviv, D.; Chen, K.W.; Teitelbaum, E.; Sheppard, D.; Pantelic, J.; Rysanek, A.; Meggers, F. A fresh (air) look at ventilation for COVID-19: Estimating the global energy savings potential of coupling natural ventilation with novel radiant cooling strategies. Appl. Energy 2021, 292, 116848. [CrossRef]

37. Faulkner, C.A.; Castellini, J.E.; Zuo, W.; Lorenzetti, D.M.; Sohn, M.D. Investigation of HVAC operation strategies for office buildings during COVID-19 pandemic. Build. Environ. 2021, 207, 108519. [CrossRef] [PubMed]

38. Mokhtari, R.; Jahangir, M.H. The effect of occupant distribution on energy consumption and COVID-19 infection in buildings: A case study of university building. Build. Environ. 2021, 190, 107561. [CrossRef] [PubMed]

39. Schibuola, L.; Tambani, C. High energy efficiency ventilation to limit COVID-19 contagion in school environments. Energy Build. 2021, 240, 110882. [CrossRef] [PubMed]

40. Lourenço, J.M.; Aelenei, L.; Facão, J.; Gonçalves, H.; Aelenei, D.; Pina, J.M. The Use of Key Enabling Technologies in the Nearly Zero Energy Buildings Monitoring, Control and Intelligent Management. Energies 2021, 14, 5524. [CrossRef]

41. Lund, S.; Madgavkar, A.; Manyka, J.; Smit, S. What's next for Remote Work: An Analysis of 2,000 Tasks, 800 Jobs, and Nine Countries; Open Interactive Popup, McKinsey Global Institute: New York, NY, USA, 2020.

42. He, H.; Neumark, D.; Weng, Q. Do Workers Value Flexible Jobs? A Field Experiment; NBER Working Paper Series; National Bureau of Economic Research: Cambridge, MA, USA, 2019.

43. Mori, T. The Coronavirus Pandemic and the Increase of Teleworking in Eight Countries; Nomura Research Institute: Chiyoda, Tokyo, Japan, 2021.

44. Neufeld, D. Visualizing the $\$ 94$ Trillion World Economy in One Chart. Available online: https://www.visualcapitalist.com/ visualizing-the-94-trillion-world-economy-in-one-chart/ (accessed on 3 January 2022).

45. The World Bank. GDP Growth (Annual \%)—China I Data. Available online: https://data.worldbank.org/indicator/NY.GDP. MKTP.KD.ZG?locations=CN (accessed on 3 January 2022).

46. Textor, C. GDP Composition in China 2020, by Industry. Available online: https://www.statista.com/statistics/1124008/chinacomposition-of-gdp-by-industry/ (accessed on 3 January 2022).

47. Forward Business Information Co., Ltd. Analysis Report on Market Prospect and Investment Strategic Planning of the China's Intelligent Mobile Office Industry from 2021 to 2026; Forward (Qianzhan) Intelligence Co., Ltd: Shenzhen, China, 2020.

48. Bai, L.; Yang, L.; Song, B.; Liu, N. A new approach to develop a climate classification for building energy efficiency addressing Chinese climate characteristics. Energy 2020, 195, 116982. [CrossRef]

49. Feng, W.; Huang, K.; Levine, M.; Zhou, N.; Zhang, S. Evaluation of Energy Savings of the New Chinese Commercial Building Energy Standard. In Proceedings of the ACEEE Summer Study on Energy Efficiency in Buildings; Office of Energy Efficiency and Renewable Energy: Pacific Grove, CA, USA, 2014; pp. 4-121-4-132.

50. Cipriano, J.; Mor, G.; Chemisana, D.; Pérez, D.; Gamboa, G. Evaluation of a multi-stage guided search approach for the calibration of building energy simulation models. Energy Build. 2015, 87, 370-385. [CrossRef]

51. Coakley, D.; Raftery, P.; Keane, M. A review of methods to match building energy simulation models to measured data. Renew. Sustain. Energy Rev. 2014, 37, 123-141. [CrossRef]

52. Shin, M.; Haberl, J.S. Thermal zoning for building HVAC design and energy simulation: A literature review. Energy Build. 2019, 203, 109429. [CrossRef]

53. Cove.tool. Sustainable Building Design; cove.tool: Atlanta, GA, USA, 2021.

54. Garwood, T.L.; Hughes, B.R.; Oates, M.R.; O'Connor, D.; Hughes, R. A review of energy simulation tools for the manufacturing sector. Renew. Sustain. Energy Rev. 2018, 81, 895-911. [CrossRef] 
55. Forouzandeh, N.; Tahsildoost, M.; Zomorodian, Z.S. A review of web-based building energy analysis applications. J. Clean. Prod. 2021, 306, 127251. [CrossRef]

56. Feng, W.; Levine, M. Commercial Building Energy Efficiency Standards \& Performance Evaluation; US Department of Energy and Lawrence Berkeley National Laboratory: Berkeley, CA, USA, 2015.

57. Pacific Northwest National Laboratory. ASHRAE Standard 90.1-Prototype Building Models Large Office I Building Energy Codes Program; Office of Energy Efficiency and Renewable Energy: Washington, DC, USA, 2020.

58. Hong, T.; Li, C.; Yan, D. Updates to the China Design Standard for Energy Efficiency in public buildings. Energy Policy 2015, 87, 187-198. [CrossRef]

59. Engineering ToolBox. Emissivity Coefficients Materials. Available online: https://www.engineeringtoolbox.com/emissivitycoefficients-d_447.html (accessed on 30 July 2020).

60. Bai, L.; Wang, S. Definition of new thermal climate zones for building energy efficiency response to the climate change during the past decades in China. Energy 2019, 170, 709-719. [CrossRef]

61. American Society of Heating, Refrigerating and Air-Conditioning Engineers (ASHRAE); American National Standards Institute (ANSI). ANSI/ASHRAE Standard 55-2017-Thermal Environmental Conditions for Human Occupancy; American Society of Heating, Refrigerating and Air-Conditioning Engineers: Peachtree Corners, GA, USA, 2017.

62. American Society of Heating, Refrigerating and Air-Conditioning Engineers (ASHRAE); American National Standards Institute (ANSI). ANSI/ASHRAE Standard 52.2-2017-Method of Testing General Ventilation Air-Cleaning Devices for Removal Efficiency by Particle Size; American Society of Heating, Refrigerating and Air-Conditioning Engineers: Peachtree Corners, GA, USA, 2017.

63. Population of Cities in China. 2021. Available online: https://worldpopulationreview.com/countries/cities/china (accessed on 12 March 2021).

64. Bai, L.; Yang, L.; Song, B. The impact of climate change on thermal climate zones and residential energy efficiency designs during the past decades in China. Adv. Build. Energy Res. 2020, 14, 389-402. [CrossRef]

65. Brinkhoff, T. Population Statistics for Countries, Administrative Divisions, Cities, Urban Areas and Agglomerations. Available online: https:/ / www.citypopulation.de/ (accessed on 15 March 2021).

66. American Society of Heating, Refrigerating and Air-Conditioning Engineers (ASHRAE). ASHRAE Handbook; ASHRAE: Atlanta, GA, USA, 2020.

67. (CEN) EN 15232; Energy Performance of Buildings-Impact of Building Automation, Controls and Building Management. European Committee for Standardization: Brussels, Belgium, 2017.

68. TRANE Technologies. ASHRAE Recommendations for COVID-19; Engineers Newsletter, 49/2; TRANE Technologies: Dublin, Ireland, 2020.

69. Li, Y. Effects of Building Ventilation on SARS-CoV-2 Transmission-A Preliminary Study. Presented at the ASHRAE 2020, Virtual Conference, Virtual, 29 June-2 July 2020.

70. Spena, A.; Palombi, L.; Corcione, M.; Carestia, M.; Spena, V.A. On the Optimal Indoor Air Conditions for SARS-CoV-2 Inactivation. An Enthalpy-Based Approach. Int. J. Environ. Res. Public Health 2020, 17, 6083. [CrossRef]

71. North Carolina Department of Administration (NCDA). Specification for Filters, AIR (HVAC); North Carolina Department of Administration (NCDA): Raleigh, NC, USA, 2017.

72. Ahlawat, A.; Wiedensohler, A.; Mishra, S.K. An Overview on the Role of Relative Humidity in Airborne Transmission of SARS-CoV-2 in Indoor Environments. Aerosol Air Qual. Res. 2020, 20, 1856-1861. [CrossRef]

73. Engineering ToolBox Fans. Efficiency and Power Consumption. Available online: https://www.engineeringtoolbox.com/fansefficiency-power-consumption-d_197.html (accessed on 3 April 2021).

74. Brendel, M. Fan Efficiency Grade Classification for Fans. Presented at the ASHRAE Annual Meeting 2012, San Antonio, TX, USA, 23-27 June 2012.

75. Xu, P.; Peccia, J.; Fabian, M.P.; Martyny, J.W.; Fennelly, K.P.; Hernandez, M.; Miller, S.L. Efficacy of ultraviolet germicidal irradiation of upper-room air in inactivating airborne bacterial spores and mycobacteria in full-scale studies. Atmos. Environ. 2003, 37, 405-419. [CrossRef]

76. Riley, R.L.; Nardell, E.A. Clearing the Air: The Theory and Application of Ultraviolet Disinfection. Am. Rev. Respir. Dis. 1989, 139, 1286-1294. [CrossRef] [PubMed]

77. Martin, S., Jr.; Bahnfleth, W.P.; Dunn, C.; Freihaut, J.; Lau, J.; Davidovic-Nedeljkovic, A. Ultraviolet Germicidal Irradiation. Curr. Best Pract. ASHRAE J. 2008, 28-36.

78. U.S. Department of Health \& Human Services (HHS); Centers for Disease Control and Prevention (CDC); National Institute for Occupational Safety and Health (NIOSH). Environmental Control for Tuberculosis: Basic Upper-Room Ultraviolet Germicidal Irradiation Guidelines for Healthcare Settings; U.S. Department of Health and Human Services: Washington, DC, USA, 2009.

79. Kerkhoff, P.; Dijk, E. Philips Lighting. UV-C Disinfection for Air, Surfaces and Water. UV-C Market, Applications and Offering. Presented at the Signify Webinars, Eindhoven, The Netherlands, 23 June 2020.

80. Ahuja, S. What Is the Simulation Engine Being Used? Available online: http://help.covetool.com/en/articles/2301606-what-isthe-simulation-engine-being-used (accessed on 19 March 2021).

81. Zhang, Z.Y. China Electricity Prices for Industrial Consumers. Available online: https://www.china-briefing.com/news/chinaelectricity-prices-industrial-consumers / (accessed on 5 April 2021). 
82. Paltsev, S.; Zhang, D. Natural gas pricing reform in China: Getting closer to a market system? Energy Policy 2015, 86, 43-56. [CrossRef]

83. Sarkhosh, M.; Najafpoor, A.A.; Alidadi, H.; Shamsara, J.; Amiri, H.; Andrea, T.; Kariminejad, F. Indoor Air Quality associations with sick building syndrome: An application of decision tree technology. Build. Environ. 2021, 188, 107446. [CrossRef] 